EDUARDO DARVIN RAMOS DA SILVA

Escolha de alvos coespecíficos na observação do uso de ferramentas por macacos-prego (Cebus libidinosus) selvagens 


\section{Escolha de Alvos Coespecíficos na Observação do Uso de Ferramentas por Macacos-Prego (Cebus libidinosus) Selvagens}

Dissertação apresentada no Instituto de Psicologia da Universidade de São Paulo, como parte dos requisitos para obtenção do título de Mestre em Psicologia

Área de concentração: Psicologia Experimental

Orientador: Prof. Dr. Eduardo B. Ottoni

São Paulo 
Silva, Eduardo Darvin Ramos da.

Escolha de alvos coespecíficos na observação do uso de ferramentas por macacos-prego (cebus libidinosus) selvagens Eduardo Darvin Ramos da Silva; orientador Eduardo B. Ottoni. -- São Paulo, 2008.

$87 \mathrm{p}$.

Dissertação (Mestrado - Programa de Pós-Graduação em Psicologia. Área de Concentração: Psicologia Experimental) Instituto de Psicologia da Universidade de São Paulo.

1. Macacos-prego 2. Utilização de ferramentas 3. Aprendizagem social 4. Comportamento de forrageamento animal 5. Etologia animal 6. Primatas (não humanos) I. Título. 


\section{Escolha de Alvos Coespecíficos na Observação do Uso de Ferramentas por Macacos-Prego (Cebus libidinosus) Selvagens}

EDUARDO DARVIN RAMOS DA SILVA

BANCA EXAMINADORA

Dissertação defendida e aprovada em: 


\section{AGRADECIMENTOS}

Ao Professor Eduardo B. Ottoni, pela orientação e por tudo que aprendi sobre a elaboração e condução crítica e competente de um projeto de pesquisa, pela confiança em mim depositada e por permitir que eu realizasse esse estudo.

À Professora Patrícia Izar, pela precisa e dedicada ajuda sempre que precisei, pelas contribuições essenciais para a realização deste trabalho através de críticas, sugestões e dicas sobre o trabalho de campo.

À Briseida D. Resende pelas contribuições importantes, principalmente por meio do exame de qualificação, pela ajuda e paciência desde meu início de trabalho primatológico.

À minha nova Família Piauiense: Maria, Mauro, Júnior, Marcos, Marina, Mara, Martinha e Marcinho. Espero que na minha estada junto a vocês eu tenha retribuído e agradecido por meio da convivência, pois me faltam palavras para agradecer tamanha receptividade, acolhimento, amizade e hospitalidade. Pelos bons momentos de convívio agradável e descontração sob a fumaça do fogão a lenha. Pela valiosa ajuda, tanto para realização prática da pesquisa quanto para meu bem-estar pessoal. Com saudade, Muito Obrigado.

Aos meus amigos e ajudantes de campo Jozemar e Arizomar, pela valiosa ajuda na coleta de dados e pelas muitas horas de companhia sob o escaldante sol piauiense. Com vocês, meus amigos do sertão, aprendi sobre a simples felicidade da vida.

À Michele Verderane e Noemi Spagnoletti, pelo trabalho realizado em conjunto, pela troca de informações sobre os macacos e o ambiente de trabalho e pelo companheirismo. Ao Hildebrando e Michele pelas descontraídas conversas na "rua" e pelo acolhimento em sua casa, muito obrigado.

À Elisabetta Visalberghi e Dorothy Fragaszy, pelo apoio logístico e competente, essenciais para a condução deste trabalho em sua fase de coleta de dados. 
Aos amigos de Laboratório Camila, Tiago, Caio, Lucas, Marcos e Érica que direta ou indiretamente colaboraram para o desenvolvimento deste trabalho.

Ao CNPq pela concessão da bolsa de estudo.

Ao Massimo Mannu, pelo exemplo de dedicação, persistência e alegria.

Ao Grupo do Grande Zangado.

E finalmente gostaria de agradecer:

À minha Família, pela eterna companhia e força mesmo à distância. Mais uma vez com imensa alegria e de todo meu coração: Pai, Mãe, Juli e Rafa, Amo Vocês.

À minha querida Fernanda, pelo carinho e companhia incondicionais, pela paciência e apoio mesmo nos períodos mais difíceis dos doze meses que permanecemos fisicamente distantes. Muito Obrigado Fê, meu eterno amor a você. 


\section{Sumário}

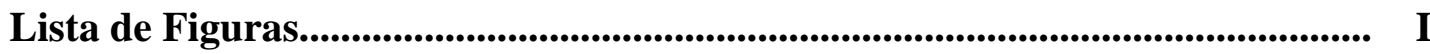

Lista de Tabelas......................................................................................... IV

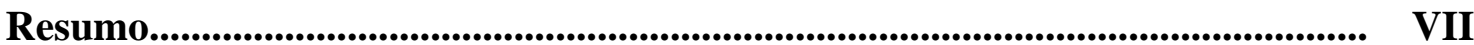

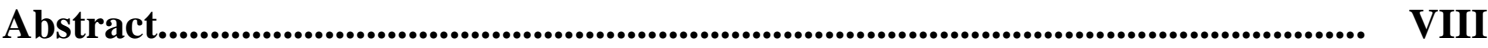

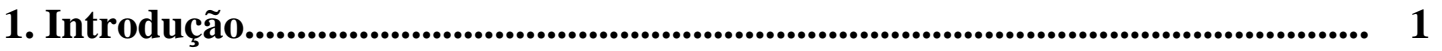

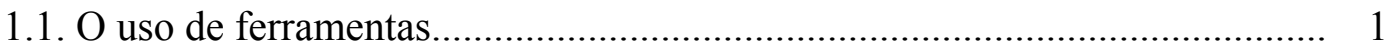

1.2. Os primatas e o uso de ferramentas......................................................... 2

1.3. O gênero Cebus.................................................................................... 5

1.3.1. O uso de ferramentas no gênero Cebus............................................. 7

1.3.2. O uso de ferramentas por Cebus libidinosus..................................... 8

1.4. A quebra de frutos encapsulados............................................................. 9

1.5. Aprendizagem socialmente mediada............................................................ 9

1.5.1. Transmissão social e tradição .......................................................... 9

1.5.2. Aprendizagem socialmente mediada em macacos-pregos.................. 12

1.5.3. Tolerância social, partilha de alimentos e observação de coespecíficos em macacos-prego...................................................... 13

1.5.4. Observação e aprendizagem socialmente mediada na quebra de frutos encapsulados................................................................... 15

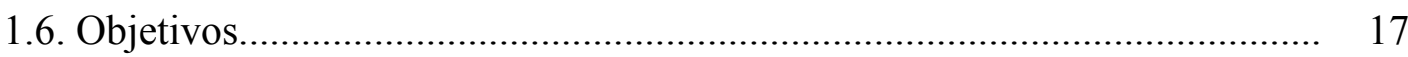

2. Material e Métodos............................................................................................... 18

2.1. Local: Fazenda Boa Vista........................................................................ 18

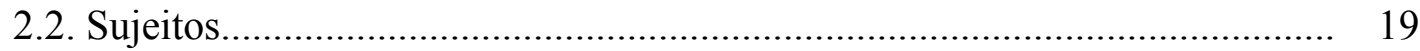

2.3. Coleta de dados................................................................................... 22

2.3.1. Registros dos episódios de quebra de cocos...................................... 23

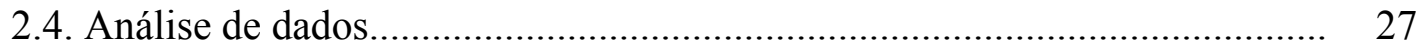

2.4.1. A Quebra de cocos........................................................................ 27

2.4.1.1. Escolha do alvo................................................................ 29

2.4.2. Outros itens alimentares................................................................... 30

2.4.3. Partilha de alimento.................................................................. 30

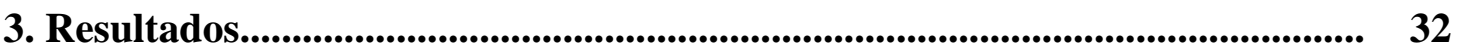

3.1. A Quebra de Cocos................................................................................ 32

3.1.1. Demografia da quebra de cocos................................................... 32

3.1.2. Proficiência do quebrador................................................................. 36

3.1.3. Observação da quebra de cocos por coespecíficos............................. 39

3.1.3.1. Comportamentos manipulativos do observador..................... 44 
3.1.4. Scrounging e a quebra de cocos................................................... 45

3.1.5. Scrounging e observação na quebra de cocos.................................... 47

3.1.6. Escolha do alvo de observação......................................................... 49

3.1.6.1. Escolha do alvo de observação: Machos e Fêmeas................ 52

3.2. A Quebra de outros itens alimentares encapsulados................................ 54

3.2.1. Demografia da quebra de outros itens encapsulados........................ 56

3.2.2. Observação e Scrounging ............................................................. 58

3.3. Partilha de alimento............................................................................. 60

3.3.1. Demografia da partilha de alimento............................................... 61

3.3.2. Partilha X Scrounging ................................................................ 64

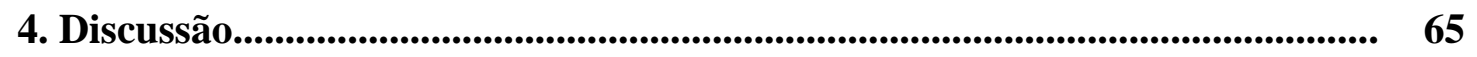

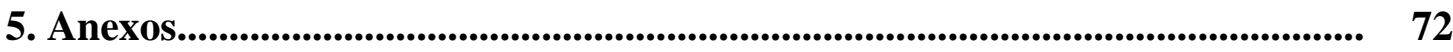

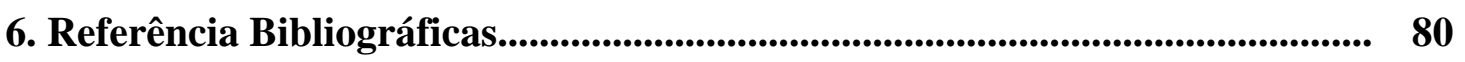




\section{Lista de Figuras}

Figura 1: Distribuição Geográfica de Cebus libidinosus no Brasil (adaptado de Fragaszy, et al., 2004) 6

Figura 2: Média dos episódios de quebra de cocos e desvios-padrão para os três períodos de coleta de dados, distribuídos por faixas etárias. $\mathrm{Ad} / \mathrm{Sub}$ : Adultos/Subadultos; Juv: Juvenis; Inf: Infantes; P1: Primeiro período; P2: Segundo período; P3: Terceiro período.

Figura 3: Média dos episódios de quebra de cocos e desvios-padrão, para os três períodos de coleta de dados, distribuídos por sexo. Machos e Fêmeas; P1: Primeiro período; P2: Segundo período; P3: Terceiro período .35

Figura 4: Taxa de proficiência individual e número de episódios de quebra nos três períodos da coleta de dados pelos métodos de Todas as Ocorrências e Evento Focal; Total de episódios proficientes dividido pelo Total de episódios. .36

Figura 5: Taxa de Proficiência para os três períodos de coleta de dados, distribuídos por sexo. Total de episódios proficientes dividido pelo total de episódios. P1: Primeiro período; P2: Segundo período; P3: Terceiro período .37

Figura 6: Taxa de Proficiência para os três períodos de coleta de dados, distribuídos por faixa etária. Total de episódios proficientes dividido pelo total de episódios. P1: Primeiro período; P2: Segundo período; P3: Terceiro período. 37

Figura 7: Taxa de produtividade individual e número de episódios de quebra nos dois períodos da coleta de dados pelos métodos de Todas as Ocorrências e Evento Focal; Total de cocos quebrados/Total de episódios de quebra. .38

Figura 8: Taxas de Observação individual dirigidas a cada sujeito-alvo durante todo o período de coleta de dados (número de episódios observacionais em que o indivíduo foi alvo dividido pelo número total de eventos de quebra de cocos por sujeito) .39 
Figura 9: Média dos episódios de observação (e desvios-padrão) dos indivíduos enquanto alvos para os três períodos de coleta, distribuídos por faixa etária. $\mathrm{Ad} / \mathrm{Sub}$ : Adultos/Subadultos; Juv: Juvenis; Inf: Infantes; P1: Primeiro período; P2: Segundo período; P3: Terceiro período.

Figura 10: Taxas de observação dos indivíduos de cada classe de sexo-faixa etária enquanto alvos para os três períodos de coleta; Total de eventos observacionais (como alvos), dividido pelo Total de episódios de quebra de cada categoria de faixa etáriasexo

Figura 11: Média de Eventos Observacionais e desvios-padrão para os três períodos de coleta, distribuídos por faixa etária. Ad/Sub: Adultos/Subadultos; Juv: Juvenis; Inf: Infantes; P1: Primeiro período; P2: Segundo período; P3: Terceiro período. .43

Figura 12: Média de Eventos Observacionais e desvios-padrão para os três períodos de coleta, distribuídos por sexo. Machos e Fêmeas; P1: Primeiro período; P2: Segundo período; P3: Terceiro período.

Figura 13: "Taxa do Doador" e número de episódios de quebra, para todo o período de coleta de dados pelo método do Evento Focal, distribuídos por sujeito (número de episódios em que cada indivíduo foi doador dividido pelo número total de episódios de quebra de cocos por sujeito). 46

Figura 14: Episódios de Observação individual da quebra de cocos em que houve (Scr) ou não houve (N Scr) Scrounging durante todo o período da coleta de dados.

Figura 15: Episódios enquanto alvos de observação em que houve (Scr) ou não houve (N Scr) Scrounging por coespecíficos durante todo o período da coleta de dados 48

Figura 16: Porcentagem dos episódios de Scrounging que resultaram de um evento de observação. Im: Scrounging Imediato; Med: Scrounging Mediato. .48

Figura 17: Porcentagem do uso de ferramentas na manipulação de $\operatorname{cocos}$ e outros itens alimentares encapsulados (maio de 2006 a agosto 2007). .54 
Figura 18: Número de Episódios de uso de ferramentas para quebra de frutos, frutos e sementes, sementes e itens não-identificados (N ID) .54

Figura 19: Média dos episódios de quebra de itens encapsulados (exceto cocos) e desvios-padrão, distribuídos por faixas etárias. Ad/Sub: Adultos/Subadultos; Juv: Juvenis; Inf: Infantes; P1: Primeiro período; P2+P3: Segundo e Terceiro períodos........57

Figura 20: Média dos episódios de quebra de itens encapsulados (exceto cocos) e desvios-padrão, distribuídos por sexo. Machos e Fêmeas; P1: Primeiro período; P2+P3: Segundo e Terceiro períodos. .57

Figura 21: Porcentagem dos episódios de Scrounging que resultaram de um evento de observação. Im: Scrounging Imediato; Med: Scrounging Mediato.

Figura 22: Itens alimentares partilhados pelo Grupo do Zangado, de maio de 2006 a abril de 2007 (método de Todas as Ocorrências) 60

Figura 23: Média de episódios de Partilha de Alimento (e desvios-padrão) dos doadores, distribuídos entre as faixas etárias. Ad/Sub: Adultos/Subadultos; Juv: Juvenis; Inf: Infantes; P1: Primeiro período; P2+P3: Segundo e Terceiro períodos.

Figura 24: Média de episódios de Partilha de Alimento (e desvios-padrão) dos receptores, distribuídos entre as faixas etárias. Ad/Sub: Adultos/Subadultos; Juv: Juvenis; Inf: Infantes; P1: Primeiro período; P2+P3: Segundo e Terceiro períodos 


\section{Lista de Tabelas}

Tabela 1: Nome, sigla, sexo, faixa etária e presença dos sujeitos no grupo estudado ao longo do período de coleta de dados - maio de 2006 até abril de 2007 (os períodos serão definidos adiante). M: Macho; F: Fêmea; A: Adulto; S: Subadulto; J: Jovem; I: Infante; $\mathrm{x} / \mathrm{x}$ : mudança de faixa etária ao longo da coleta de dados. $\Delta:$ nascimento; $\uparrow:$ óbito; $\rightarrow$ : saída do grupo (migração). P1: Primeiro Período; P2: Segundo Período; P3: Terceiro Período. 21

Tabela 2: Etograma utilizado nos registros pelo método do "Evento Focal". .25

Tabela 3: Macacos do Grupo do Zangado que apresentaram o comportamento de quebra de cocos (Adequada + Inepta + Proficiente + Não determinada), sua idade, sexo e número de episódios de quebra para todo o período de coleta de dados. M: Machos; F: Fêmeas; A: Adultos; S: Subadultos; J: Juvenis; I: Infantes; *: indivíduo ausente do grupo; P1: maio e junho de 2006; P2: julho de 2006; P3: agosto de 2006 a abril de 2007. 32

Tabela 4: Episódios de quebra (Quebra Inepta + Quebra Adequada + Quebra Proficiente + Quebra Não-Determinada) realizados pelos indivíduos do "Grupo de Zangado" durante o período de coleta, distribuídos por faixa etária. (n) = número de indivíduos por categoria em cada período. .33

Tabela 5: Episódios de quebra (Quebra Inepta + Quebra Adequada + Quebra Proficiente + Quebra Não-Determinada) realizados pelos indivíduos do "Grupo de Zangado" durante o período de coleta, distribuídos por sexo. (n) = número de indivíduos por categoria em cada período .33

Tabela 6: Episódios de observação da quebra de cocos por coespecíficos, nos três períodos de coleta pelos métodos Evento Focal e Todas as Ocorrências, distribuídos por categorias de sexo 40 
Tabela 7: Episódios de observação da quebra de cocos por coespecíficos, nos três períodos de coleta pelos métodos Evento Focal e Todas as Ocorrências, distribuídos por faixa etária

Tabela 8: Comportamentos Manipulativos do observador após os eventos de observação de quebra de cocos. As colunas indicam a categoria do episódio de quebra exibido pelo alvo de observação. QI: Quebra Inepta; QA: Quebra Adequada; Quebra Proficiente. Dados coletados pelo método do Evento Focal .44

Tabela 9: Episódios de Scrounging da quebra de cocos por coespecíficos, nos três períodos de coleta de dados pelo método Evento Focal, distribuídos pelas categorias de sexo.

Tabela 10: Episódios de Scrounging da quebra de cocos por coespecíficos, nos três períodos de coleta de dados pelo método Evento Focal, distribuídos por faixa etária....45

Tabela 11: Correlações das matrizes de Observação (matriz assimétrica) com: Proximidade de 1 metro (matriz simétrica); Proximidade de 10 metros (matriz simétrica); Postos Hierárquicos (matriz hipotética); Freqüência de Quebra (matriz hipotética); Taxa de Proficiência na Quebra (matriz hipotética) e Taxa de Produtividade na Quebra (matriz hipotética). P1: primeiro período; P2: segundo período; P3: terceiro período.

Tabela 12: Correlações das matrizes de Scrounging (matriz assimétrica) com: Proximidade de 1 metro (matriz simétrica); Proximidade de 10 metros (matriz simétrica); Postos Hierárquicos (matriz hipotética); Freqüência de Quebra (matriz hipotética); Taxa de Proficiência na Quebra (matriz hipotética) e Taxa de Produtividade na Quebra (matriz hipotética). P1: primeiro período; P2: segundo período; P3: terceiro período. .50

Tabela 13: Correlações das matrizes de Observação (matriz assimétrica) com: Proximidade de 1 metro (matriz assimétrica); Proximidade de 10 metros (matriz assimétrica); Postos Hierárquicos (matriz hipotética); Freqüência de Quebra (matriz hipotética); Taxa de Proficiência na Quebra (matriz hipotética) e Taxa de Produtividade 
na Quebra (matriz hipotética). P1-Machos: primeiro período - somente alvos machos;

P3-Fêmeas: terceiro período - somente alvos fêmeas .53

Tabela 13: Lista de espécies manipuladas com o uso de ferramentas pelos macacos do Grupo do Zangado durante todo período. $\mathrm{F}=$ Fruto; F/S = Fruto e Semente; Fo = Folha .55

Tabela 14: Macacos do Grupo do Zangado que apresentaram o comportamento de quebra de itens encapsulados - não incluindo cocos (idade, sexo e número de episódios de quebra para todo o período de coleta de dados). M: Machos; F: Fêmeas; A: Adultos; S: Subadultos; J: Juvenis; I: Infantes; *: indivíduo ausente do grupo; P1: maio e junho de 2006; P2+P3: julho de 2006 a abril de 2007 .56

Tabela 15: Episódios de Partilha de Alimento por coespecíficos, nos três períodos de coleta pelo método de Todas as Ocorrências, distribuídos por categorias de sexo 61

Tabela 16: Episódios de Partilha de Alimento, nos três períodos de coleta pelo método de Todas as Ocorrências, distribuídos por faixa etária

Tabela 17: Correlações das matrizes de Partilha de Alimento (matriz assimétrica) com: Proximidade de 1 metro (matriz simétrica); Proximidade de 10 metros (matriz simétrica); Postos Hierárquicos (matriz hipotética). P1: primeiro período; P2+P3: segundo e terceiro períodos 


\section{$\underline{\text { Resumo }}$}

Silva, E. D. R. Escolha de alvos coespecíficos na observação do uso de ferramentas por macacos-prego (Cebus libidinosus) selvagens. São Paulo, 2008, 87p. Dissertação (Mestrado). Instituto de Psicologia, Universidade de São Paulo.

A quebra de frutos encapsulados por macacos-prego com o auxílio de ferramentas é tipicamente objeto de observação e scrounging por coespecíficos, bastante tolerados e em geral mais jovens e menos proficientes. $\mathrm{O}$ presente estudo teve como objetivo examinar o processo de escolha, pelos observadores, dos alvos de observação, e se esta escolha pode otimizar as oportunidades de scrounging. A pesquisa foi realizada com um grupo de macacos-prego selvagens (Cebus libidinosus) na Fazenda Boa Vista (Piauí - Brasil), numa área de ecótono cerrado/caatinga. A partilha de alimento fora dos episódios de quebra de cocos e o uso de ferramentas para a quebra de outros itens alimentares encapsulados também foram abordados. Indivíduos de todas as classes de idade e sexo se envolveram na observação da quebra de cocos, havendo uma grande variação individual. Nossas análises mostram que os macacos preferencialmente escolhidos como alvos de observação foram aqueles que apresentaram maior Freqüência, Proficiência e Produtividade na quebra de cocos. Apesar de haver interações agonísticas durante os eventos de observação, os alvos se mostram muito tolerantes à observação e ao scrounging - $25 \%$ dos episódios de quebra são observados e mais da metade destes eventos de observação resultam em scrounging. Os observadores tiveram a oportunidade de comer os restos dos cocos e de manipular os itens do sítio de quebra. Estas observações reforçam a noção de que as condições e possibilidades vivenciadas pelo observador-scrounger otimizam as oportunidades para que ocorram processos de aprendizagem socialmente mediada, ao menos por realce de estímulo. Tal exposição próxima ao comportamento do alvo poderia influenciar aspectos mais finos do comportamento dos observadores, ao longo de sua história de aprendizagem. O presente estudo aborda estas interações entre manipuladores de ferramentas e observadores/scroungers pela primeira vez em uma população selvagem e discute as semelhanças e discrepâncias em relação aos resultados anteriormente obtidos com uma população em semil-liberdade. 


\section{$\underline{\text { Abstract }}$}

Silva, E. D. R. Choice of conspecific targets in the observation of tool use by wild bearded capuchin monkeys (Cebus libidinosus). São Paulo, 2008, 87p. Dissertação (Mestrado). Instituto de Psicologia, Universidade de São Paulo.

The tool-aided cracking of encapsulated fruit by capuchin monkeys is a frequent target of observation and scrounging by conspecifics, well-tolerated and usually younger and less proficient. The present study aimed to examine the process of observational targets' choice by the observers, and whether this choice can optimize scrounging opportunities. The research was conducted with a group of wild bearded capuchin monkeys (Cebus libidinosus) in Fazenda Boa Vista (Piauí, Brazil), in an ecotone area between "cerrado" and "caatinga" savanna-like environments. Food sharing in contexts other than nut cracking, as well as the use of tools to crack open other food items were also analyzed. Individuals from all age and sex classes were involved in nut cracking observation. Our analyses show that the monkeys preferentially chosen as observational targets were the ones exhibiting the greater Frequency, Proficiency, and Productivity in nut cracking. In spite of a few agonistic interactions during observation events, the targets tend to be very tolerant to observation and to scrounging (25\% of the nut cracking events are observed, and more than half of these resulted in scrounging). The observers had the opportunity of eating nuts' leftovers and of manipulating items from the cracking sites, both in the presence and in the absence of the targets. These findings strengthen the idea that the conditions and possibilities experienced by the observers-scroungers optimize the opportunities for socially biased learning processes, at least by stimulus enhancement. Such close exposure to the target's behavior could also influence finer details of the observers' behavior in the long run. The present study is the first one to deal with these interactions between tool manipulators and observers/scroungers in a wild population and discusses the similarities and differences from previous observations from a semi-free population. 


\section{Introducão}

Com um período relativamente longo de imaturidade e intenso cuidado parental, os primatas têm a oportunidade de aprender muito sobre o ambiente físico e social (Tomasello \& Call, 1997). A observação de coespecíficos permite que indivíduos possam adquirir práticas comportamentais comuns ao grupo, a partir da experiência de outros indivíduos.

Segundo Coussi-Korbel \& Fragaszy (1995) a interação próxima entre os indivíduos permite que o observador tenha melhores chances de adquirir informação detalhada sobre o comportamento do alvo de observação. Porém, para que isso ocorra é preciso que o outro indivíduo tolere a presença próxima do observador. Outro fator que limita a aprendizagem socialmente mediada é o grau de interesse que um indivíduo tem sobre a atividade de outros coespecíficos.

Os macacos-prego têm grande interesse em observar a ação de outros indivíduos do grupo (orientação social) e são altamente tolerantes quanto à presença de coespecíficos de seu grupo social (Fragaszy et al., 2004a). Exibem uma dieta onívora e forrageamento extrativo, se engajando muito tempo na manipulação de alimentos e objetos. Devido à sua grande capacidade manipulativa e cognitiva, o macaco-prego desenvolve muitas técnicas complexas em suas atividades de forrageamento, incluindo o uso de ferramentas. A aquisição destas sofisticadas técnicas de manipulação pode envolver mecanismos de transferência social de informação (King, 1991).

Nesse contexto, o presente estudo vem abordar a quebra de cocos e de outros itens alimentares com o uso de ferramentas, a partilha do endosperma do coco obtido pela quebra, a dinâmica da observação da quebra por coespecíficos e como se da a escolha do alvo pelo observador da quebra de cocos.

\subsection{O uso de ferramentas em animais}

O uso de ferramentas é um comportamento de grande relevância na evolução dos hominídeos, sendo, no passado, considerado como uma característica que diferenciava os seres humanos dos outros animais. Hoje se percebe tal comportamento é amplamente distribuído no reino animal (ver van Lawick-Goodall, 1970; Beck, 1980). Entendemos como uso de ferramentas a utilização de um objeto externo como uma 
extensão funcional do corpo do animal, para agir em outro objeto ou superfície, para atingir um objetivo imediato (van Lawick-Goodall, 1970.).

Identificamos inúmeros casos de uso de ferramentas entre os animais: aranhas de deserto (Ariadna) tipicamente colocam sete ou oito pedras de quartzo num circulo ao redor da entrada de sua toca (Henschel, 1995), aumentando, assim, segundo o autor, a área de detecção de presas; corvos da Nova Caledônia usam gravetos para procurar e puxar insetos de buracos (Hunt, 1996); o abutre egípcio (Neophron percnopterus) joga pedras em cima de ovos de avestruz para quebrá-los (van Lawick-Goodall, 1966, apud. van Lawick-Goodall, op cit.) e lontras marinhas (Enhydra lutris) quebram conchas de moluscos em "bigornas" de pedra que seguram em seu tórax (Hall \& Schaller, 1964, apud. Van Lawick-Goodall, op cit.).

Segundo van Lawick-Goodall (1970), embora o uso de ferramentas seja amplamente difundido no reino animal, os processos evolutivos que levaram as diferentes espécies a utilizarem objetos são indubitavelmente diferentes. A autora ainda argumenta que algumas atividades, como a construção de ninhos, não deveriam ser enquadradas nesta definição, pois as mãos, garras, bocas ou bicos são as próprias ferramentas e as folhas e galhos, os materiais sendo manipulados.

$\mathrm{Na}$ maioria dos casos, a utilização de ferramentas ocorre de maneira estereotipada/inata. Em outros, ela se dá de forma flexível/aprendida, com alta variabilidade dentro da mesma espécie. Cabe ressaltar que a estereotipia e a plasticidade não são processos mutuamente exclusivos, havendo um continuo entre os dois extremos. Embora os primatas encontrem-se na extremidade flexível do continuo, há uma grande variabilidade na propensão manipulativa e na capacidade cognitiva entre as espécies, poucas sendo conhecidas pelo uso de ferramentas de forma espontânea na natureza.

\subsection{Os primatas e o uso de ferramentas}

Os primatas são conhecidos pela sua grande encefalização, neocórtex expandido e pela cognição desenvolvida (Dunbar, 1992; Fleagle, 1999). As mãos constituem uma adaptação morfológica muito útil para seu forrageamento: além de serem usadas para procurar e pegar alimentos, também podem ser usadas para ajudar a processá-los (Tomasello \& Call, 1997). A destreza manipulativa varia entre as espécies, mas, de uma maneira geral, adaptações cognitivas e morfológicas permitem que os primatas 
manipulem objetos de maneira mais flexível e esse tipo de manipulação pode envolver processos cognitivos complexos.

Entre os prossímios, não encontramos relatos do uso de ferramentas, mesmo em aye-aye (Daubentonia), que é uma espécie extremamente hábil e com alto grau de encefalização. No entanto, isso é facilmente explicado pelas suas adaptações morfológicas especializadas para o forrageamento. Os animais desta espécie possuem os dedos longos e finos, com o dedo médio das mãos particularmente comprido e utilizado para retirar larvas de insetos do interior dos troncos. Sterling (1993, apud Sterling \& Povinelli, 1999) relatou apenas observações de aye-ayes utilizando lianas como apoio para otimizar o acesso a certos recursos alimentares.

Embora haja muitos relatos de uso espontâneo de ferramentas por primatas em cativeiro, poucas espécies o fazem comumente na natureza. Os Pongídeos são conhecidos pela mais extensa e flexível utilização de ferramentas desde os experimentos de Köhler (1927, apud. Beck, 1980) com chimpanzés cativos que conectavam varas ou empilhavam caixas para alcançar o alimento suspenso. Em cativeiro, há uma extensa literatura sobre o uso de ferramentas por Pongídeos, como exemplo, temos o trabalho de Rumbaugh (1977, apud Savage-Rumbaugh \& Lewin, 1994), em que chimpanzés e bonobos usam um teclado para se comunicar.

O chimpanzé (Pan troglodytes) é, dentre as espécies de primatas não-humanos, aquela que possui a maior complexidade e variedade no uso de ferramentas, ao menos em ambiente natural (McGrew, 1992). Há muitos relatos do uso de ferramentas na natureza por esta espécie, como o uso de gravetos para "pescar" insetos sociais (formigas e cupins), o uso de folhas para higiene pessoal e como esponja para absorver a água da chuva de lugares que não conseguiam alcançar com a boca (Goodall, 1970 e 1990; McGrew, 1992, Whiten et al., 1999), além do uso de pedras e troncos para quebrar cocos que foi observado em diferentes grupos do oeste africano (Costa do Marfim: Boesch \& Boesch, 1983; Guiné Bissau: Matsuzawa, 1994). Em Serra Leoa, Alp (1997) viu chimpanzés usando galhos como "assento" e como "apoio" (steppingsticks) para se proteger dos espinhos, durante o forrageamento nas árvores de Ceiba petranda. Recentemente, Pruetz \& Bertolani (2007) relataram o uso de ferramentas como "lanças" por chimpanzés da savana para caçar pequenos prossímios noturnos (Galago senegalensis) que dormem, durante o dia, dentro de cavidades nos galhos e troncos de árvores. Os chimpanzés manufaturam essas lanças utilizando múltiplos passos e as usam para alcançar suas presas nas tocas de dormida. 
Não havia registros de uso de ferramentas na natureza por gorilas (Gorilla gorilla), embora estes fossem reconhecidamente bastante proficientes no cativeiro (Tomasello \& Call, 1997). No entanto, Breuer et al. (2005) observaram gorilas selvagens do oeste africano utilizando ferramentas como "cajados" para a sustentação do corpo. Por se tratar de um ambiente pantanoso, o autor levanta a hipótese da ferramenta ser utilizada, em alguns casos, para se testar a profundidade da água ou a consistência do solo. Anteriormente, Byrne \& Russon (1998) observaram seqüências comportamentais estruturalmente complexas, comparáveis em complexidade ao uso de ferramentas, na manipulação, pelos gorilas, de determinados alimentos.

Nos orangotangos (Pongo pigmaeus), com exceção da construção de ninhos para descanso, pouco se sabia sobre o uso de ferramentas por animais selvagens, conhecendo-se apenas vários relatos em condições não-naturais como cativeiro e centros de reabilitação (Byrne, 1995; Russon \& Galdikas, 1993). Atualmente sabe-se que orangotangos selvagens apresentam diversas formas de uso de ferramentas na natureza, como palitos para extrair sementes de difícil acesso do interior de frutos (Neesia sp.), o uso de varetas para extrair mel de colméias ou insetos sociais de ocos de árvores e o uso de folhas para limpar o rosto (van Shaik et al., 1996; van Shaik et al., 2003). Fox \& bin'Muhammad (2002) observaram orangotangos selvagens de Sumatra apresentando duas novas formas de uso de ferramentas. O uso de um galho como "gancho" para alcançar outra árvore durante a locomoção e a utilização de um "aglomerado" de folhas nas mãos e nos pés para se mover em árvores com espinhos (Erythrina sp.).

Já a falta de relatos do uso de ferramentas em bonobos selvagens (Pan paniscus) ainda permanece intrigante, dada sua semelhança com seu parente mais próximo, o chimpanzé, e seu excelente desempenho em experimentos de laboratório (SavageRumbaugh \& Lewin, 1994).

Propondo uma tipologia para definir e classificar os vários tipos de manipulação de objetos e o uso de ferramentas, Parker e Gibson (1977) sugeriram que o uso flexível de ferramentas seria esperado em espécies com forrageamento extrativo de alimentos limitados sazonalmente e uma dieta onívora. No entanto, muitos animais que possuem técnicas de forrageamento extrativo utilizam ferramentas em cativeiro, mas não fazem o uso na natureza, como os gêneros Mandrillus, Theropithecus e Cercopithecus (King, 1986). 
No modelo de van Schaik et al. (1999), a precondição geral para todos os primatas que usam ferramentas para alimentação envolve forrageamento extrativo (destreza manual) e oportunidade ecológica. Porém os autores propõem outras duas variáveis que seriam necessárias para o surgimento e evolução do uso de ferramentas em primatas na natureza: capacidade cognitiva, necessária para invenção e rápida aquisição de novas técnicas complexas de forrageamento envolvendo objetos, e tolerância social, que permite a observação próxima das atividades de outros indivíduos.

Dentre as espécies de primatas do Novo Mundo, a única que atende a todos os critérios de van Schaik (op cit.), vindo a corroborar sua hipótese por utilizar ferramentas em seu habitat natural, é o macaco-prego.

\subsection{O Gênero Cebus}

Flexibilidade, oportunismo e adaptabilidade são as marcas do sucesso adaptativo dos animais do gênero Cebus (Fragaszy et al., 2004a). Os primatas deste gênero são altamente manipulativos e encefalizados. Dentre os macacos do Novo Mundo, chamam a atenção por apresentarem a maior variabilidade e maiores taxas de uso de ferramentas em cativeiro e em campo, além dos melhores desempenhos em experimentos que envolvem manipulação complexa de objetos (Fragaszy et al., 1990; Visalberghi \& Limongelli, 1994).

Mesmo estando separados filogeneticamente por mais de 40 milhões de anos, estes macacos platirrinos, sob certos aspectos, são comparados aos chimpanzés (Pan troglodytes) por compartilharem muitas características peculiares: alta tolerância social, longo período de infância, partilha de alimento além da díade mãe-filhote, predação de vertebrados, alta razão neocortical, além da utilização espontânea de ferramentas (Visalberghi \& McGrew, 1997).

Os macacos do gênero Cebus habitam quase toda a região neotropical, seu habitat é o mais diversificado dos primatas neotropicais; utilizam todos os estratos arbóreos de florestas chuvosas inundáveis ou não, florestas primárias, secundárias, caatinga, palmeiras, campos e mangues, conseqüentemente adaptando-se a uma alimentação onívora grandemente variada. Alimentam-se de frutos, sementes, castanhas, flores, gomas, néctar, fungos, seiva, ovos, invertebrados, pequenos vertebrados e até algumas espécies de ostras e caranguejos em regiões costeiras (Fragaszy et al., 2004a). 
O gênero Cebus tem sido considerado como um dos grupos taxonômicos mais confusos entre os mamíferos neotropicais, sendo divididos em dois grupos: os caiararas (sem tufo) e os macacos-prego (com tufo) (Silva, Jr., 2001). Os grupos com e sem tufo foram elevados à categoria de subgêneros, devido à grande diferenciação observada em diversos sistemas biológicos, ao padrão de distribuição geográfica, e à detecção de prováveis grupos de espécies dentro de cada subgênero. O subgênero nominal corresponde aos Cebus sem tufo, e o nome disponível para o outro subgênero é Sapajus Kerr, 1792. O subgênero Cebus foi dividido em quatro espécies: Cebus capucinus, C. albifrons, C. olivaceus e C. kaapori; o subgênero Sapajus foi dividido em sete espécies: Cebus apella, C. macrocephalus, C. libidinosus, C. cay, C. xanthosternos, C. robustus e C. nigritus (Silva, Jr., op cit.).

A espécie Cebus libidinosus (antes denominada como subespécie Cebus apella libidinosus) possui pelagem castanho muito claro, com topete de pêlos curtos e negros. Distribui-se pelo Nordeste (norte do Rio São Francisco) e região Central do Brasil incluindo o Pantanal do Mato Grosso (Fragaszy, et al., 2004a - Figura 1).

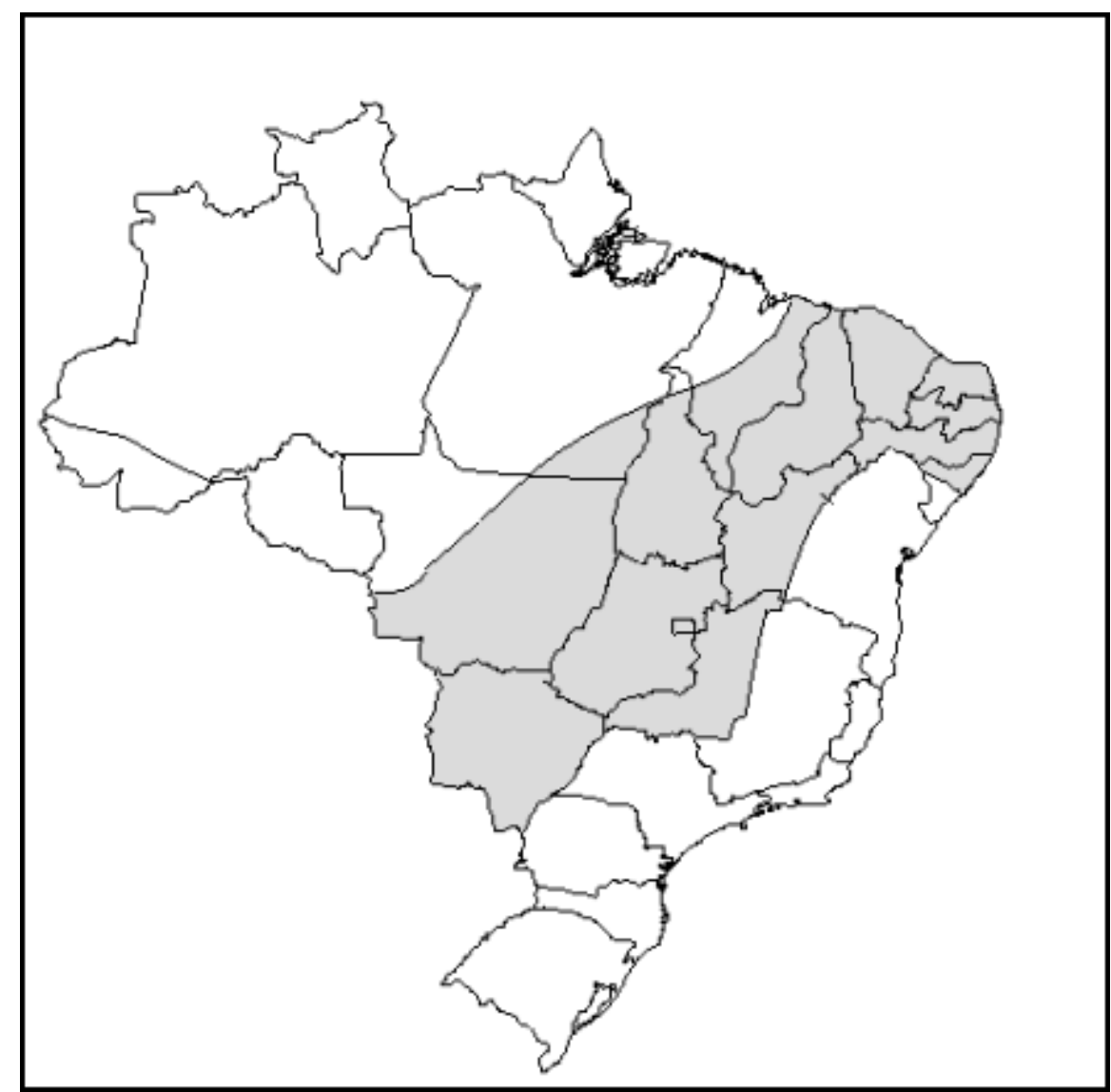

Figura 1: Distribuição Geográfica de Cebus libidinosus no Brasil (adaptado de Fragaszy, et al., 2004a). 


\subsubsection{O uso de ferramentas no gênero Cebus}

Dentre os caiararas, Boinski (1988) relatou a utilização por um Cebus capucinus, de um galho para atacar uma cobra (Bothrops asper). Panger (1998) não observou o uso de ferramentas em seu trabalho com Cebus capucinus selvagens; a autora concluiu que existe grande diferença entre o observado nos animais em cativeiro e o que se observa em campo. E que o fato de não ter sido registrado o uso de ferramentas em seu estudo poderia ser reflexo da raridade do comportamento, de diferenças específicas e ambientais, e/ou de variações populacionais. Em 1998, Philips observou C. albifrons utilizando folhas como copinhos para retirar água das cavidades de árvores.

Há vários relatos sobre a manipulação espontânea de objetos e alimentos por animais do gênero Cebus em cativeiro. Neste trabalho iremos nos ater aos macacosprego. Cooper \& Harlow (1961) relataram o uso de uma vara como arma por C. apella para agredir C. albifrons alojados no mesmo cativeiro e Ferreira et al. (1996) observaram indivíduos da espécie C. apella utilizando pedras para amolecer o fruto de Terminalia catappa em uma ilha natural no Zoológico de Recife.

Muitos experimentos também foram conduzidos nos quais animais da espécie $C$. apella que deveriam solucionar tarefas motoras utilizando ferramentas ou manipular equipamentos (Fragaszy \& Adams-Curtis, 1991; Visalberghi et al. 1995; Resende, 1999; Westergaard \& Suomi, 1994). Os resultados indicam que estes animais possuem um vasto repertório motor e conseguem realizar com sucesso tarefas complexas de manipulação, como inserir varas em tubos ou abrir trincos para obter recompensas. No entanto, evidências sugerem que os macacos-prego não entendem a relação entre os objetos no uso de ferramentas e não aprendem depois de poucas exposições à tarefa, seja por imitação ou emulação (Limongelli et al., 1995; Visalberghi et al., 1995; Tomasello \& Call, 1997).

Anderson (1990) realizou um experimento no laboratório em que macacos-prego desempenhavam uma tarefa de quebra de nozes usando pedras. Apesar dos resultados, o autor supôs que, em função do seu hábito arbóreo, esses animais não fariam tal uso na natureza.

Realmente, até o início da década de 90 eram escassos e anedóticos os relatos na literatura acerca do uso de ferramentas ou outros comportamentos envolvendo manipulação sofisticada de objetos em condições naturais; estas observações, em geral, se dão em situações de forrageamento (Chevalier-Skolnikoff, 1990). Struhsaker \& 
Leland (1977), observaram macacos-prego (Cebus apella) quebrando cocos de Astrocaryum chambira batendo-os uns contra o outro ou contra os galhos e troncos de árvores.

Rocha (et al., 1998) e Ottoni \& Mannu (2001), estudando diferentes grupos em semi-liberdade, relataram o uso espontâneo de ferramentas por Cebus apella para a quebra de cocos Syagrus romanzoffiana, e obtenção de endosperma e larvas de coleópteros que parasitam tais sementes.

Na natureza, Fernandes (1991) observou um indivíduo da espécie Cebus apella abrindo conchas de ostras apoiando-as na árvore de mangue e batendo com outro objeto (provavelmente outra ostra). Langguth \& Alonso (1997), na caatinga do interior da Paraíba, ouviram macacos-prego batendo pedras e encontraram cocos quebrados nos sítios, que supostamente foram utilizados pelos animais, concluindo que esse comportamento seria raro e que ocorreria devido à escassez alimentar. No entanto, o grupo em semi-liberdade estudado por Ottoni \& Mannu (op cit.) não passa por períodos de escassez alimentar, visto que recebe provisão de alimentos todos os dias.

\subsubsection{O uso de ferramentas por Cebus libidinosus}

Além do relato de Langguth \& Alonso (op cit.) onde os macacos eram provavelmente $C$. libidinosus, não havia na literatura relatos de uso de ferramentas por animais desta espécie em ambiente natural.

Moura \& Lee (2004) observaram o uso sistemático de ferramentas por quatro grupos de Cebus libidinosus selvagens na caatinga do estado do Piauí (Serra da Capivara). Mannu \& Ottoni (submetido), na mesma região, descrevem detalhadamente o uso e manufatura de vários tipos ferramentas por esses animais.

Ainda no Piaú, numa região mais ao sul, Fragaszy et al. (2004b) relataram o uso rotineiro de pedras para quebrar cocos em uma população selvagem de Cebus libidinosus, onde a técnica descrita se assemelha à utilizada para a quebra de cocos por chimpanzés. Este foi o primeiro registro do uso de ferramentas para a quebra de cocos por C. libidinosus selvagens, porém há um crescente número de relatos em outras áreas na região central do Brasil (Ottoni \& Izar, no prelo). 


\subsection{A quebra de frutos encapsulados}

Usar uma pedra ou pedaço de madeira ("martelo") para quebrar cocos posicionados sobre uma superfície sólida ("bigorna”) é considerado a forma mais complexa de uso rotineiro de ferramentas de forma espontânea por animais nãohumanos observado em ambiente natural, por envolver duas relações espaciais em seqüência (Fragaszy et al., 2004b). Até o presente momento o uso de tal técnica de forma espontânea na natureza é conhecido apenas em chimpanzés (Pan troglodytes) e macacos-prego (Cebus libidinosus e Cebus xanthosternos) (Boesch \& Boesch, 1983; Matsuzawa 1994; Fragaszy et al., 2004b, Ottoni \& Izar, no prelo). Entre os chimpanzés Matsuzawa (op cit) descreve, ainda, o uso de calços sob bigornas tortas para facilitar a quebra de frutos encapsulados.

\subsection{Aprendizagem Socialmente Mediada}

\subsubsection{Transmissão Social e Tradição}

Animais que vivem em grupos sociais, além de aprender a partir da própria experiência, podem aprender a partir das experiências dos outros indivíduos. No entanto, há muita controvérsia em relação aos processos que atuam na aprendizagem socialmente mediada (ver adiante). Heyes (1993) afirma que a confusão se instaurou porque diferentes escolas deram nomes diferentes para os mesmos fenômenos. Neste trabalho iremos abordar apenas processos de aprendizagem a seguir por serem eles suficientes e os mais relevantes para discussão dos nossos objetivos, além de abrangerem as principais linhas de pesquisa na área.

O realce de estímulo ou de local (stimulus ou local enhancement) (Whiten \& Ham, 1992). Esse processo de aprendizagem ocorre quando as interações de um indivíduo com o ambiente, ou os resultados desta ação, aumentam a probabilidade de outros indivíduos serem atraídos a este determinado elemento ambiental, permitindo que estes indivíduos aprendam algo no local.

A emulação de metas (goal emulation) (Whiten \& Ham, 1992) ocorre quando um sujeito aprende para onde dirigir seu comportamento ou qual meta deve ser atingida, através da observação de outro, porém não replica precisamente o comportamento do alvo. 
O termo imitação estaria restrito aos casos em que um animal alcança determinada meta executando a replica exata de um novo comportamento como resultado da observação da atividade de outro indivíduo (Heyes, 1993). O fato de haver muitos processos que levam o comportamento de um observador a se parecer com o comportamento do suposto modelo torna muito difícil encontrar evidências inequívocas de imitação verdadeira (Shettleworth, 1998).

Boesch et al. (1994) descreveu como jovens chimpanzés selvagens utilizavam somente um subconjunto de comportamentos disponíveis em seu amplo repertório comportamental enquanto aprendiam a usar ferramentas para quebra de cocos observando outros indivíduos, chamando esse processo de canalização. Este subconjunto é limitado às ações que eles observam nos adultos de seu grupo social quando esses quebram cocos.

Fragaszy \& Visalberghi (2001) propõem o termo aprendizagem socialmente mediada, em substituição ao termo geral "aprendizagem social", sendo definida como uma mudança no comportamento do indivíduo, contingente a uma mudança no estado cognitivo associada à experiência, estimulada pela exposição à atividade do meio social. Segundo estas autoras, a aprendizagem socialmente mediada é erroneamente considerada menos relevante que imitação. A aprendizagem socialmente mediada é distinguida pelo contexto em que ocorre, não pelo processo cognitivo subjacente É equivocada a pressuposição de uma distinção no processo, resultado ou domínio entre aprendizagem "social" e outros tipos de aprendizagem, não havendo, na realidade, maneira de se distinguir aprendizagem "social" de aprendizagem "associal". As autoras ainda criticam a idéia de que é necessária imitação para manter uma prática comportamental comum ao grupo. Copiar o comportamento do outro (como em imitação) não é suficiente para adquirir determinada habilidade, além disso, habilidade requer repetida prática individual (Bernstein, 1996 apud. Fragaszy \& Visalberghi, op cit).

Para que ocorra aprendizagem socialmente mediada das técnicas de obtenção de alimento, é necessário que os indivíduos estejam próximos no contexto de forrageamento. Esta não é uma condição óbvia, já que a maioria dos primatas se espalha no ambiente durante o forrageamento por insetos e outras fontes alimentares dispersas. Além disso, é comum que indivíduos subordinados sejam agredidos quando se aproximam dos animais dominantes. Sabemos também que sujeitos sob o risco de ataque por coespecíficos têm dificuldade para aprender (Inoue-Nakamura \& 
Matsuzawa, 1997). Portanto, a hipótese de van Schaik et al. (1999) de que tolerância social no contexto de forrageamento extrativo facilita a aprendizagem social prediz que, em espécies com alta tolerância social, os animais podem observar proximamente as atividades de outros sujeitos e concentrar sua atenção na exploração de objetos e itens alimentares sem interferência ou agressão de coespecíficos, assim estariam mais propícios a aprender técnicas de uso de ferramentas.

O modelo também propõe efeitos da tolerância social sobre o comportamento manipulativo/exploratório (e, conseqüentemente, sobre a aprendizagem na interação direta com os objetos). Há três evidências que comprovam essa idéia. Indivíduos de espécies com alto grau de tolerância gastam mais tempo manipulando objetos em cativeiro (Thierry, 1985 apud van Schaik, et al., 1999). Indivíduos de espécies tolerantes, quando induzidos à manufatura de ferramentas para alimentação, aprendem mais rápido que espécies não-tolerantes (Tomasello \& Call, 1997). Fragaszy \& Visalberghi (1990) mostraram que a alta vigilância social em grandes grupos de macacos-prego inibe a exploração de objetos e o desenvolvimento de novos comportamentos (inovação) de uso de ferramentas.

Ao comparar duas populações de orangotangos em que a oferta de frutos de Neesia é a mesma, van Schaik et al. (1999) mostram que, na população de Sumatra, depois de os machos adultos abrirem os frutos utilizando força bruta, outros indivíduos de todas as classes de sexo/idade - comem as sementes utilizando ferramentas. Já em Bornéu, somente os machos adultos comem as sementes e não utilizam ferramenta nenhuma no processo. Essas sementes são muito nutritivas e representam grande parte da alimentação da população de Sumatra; além disso, sua oferta está correlacionada ao pico de natalidade na região, portanto, segundo o autor, é improvável que a habilidade para extrair sementes de Neesia não fosse energeticamente importante para os orangotangos de Bornéu. É importante ressaltar que em Sumatra os animais são altamente gregários e tolerantes em situações de forrageamento em que as ferramentas são utilizadas, criando, assim, condições sociais apropriadas para a transmissão das habilidades adquiridas.

Comparando diferentes locais em que chimpanzés e orangotangos são estudados, os pesquisadores encontram muitas diferenças comportamentais que, segundo eles, não podem ser atribuídas a fatores ecológicos ou diferenças genéticas. Ambos os estudos concluíram que a variação é cultural sendo um sistema comportamental transmitido socialmente (van Schaik et al., 2003; Whiten et al., 1999). 
Fragaszy \& Perry (2003) criticam tais conclusões, defendendo que comparações entre diferentes grupos e locais que exibem diferenças comportamentais, não podem, por si, mostrar que determinado comportamento é ou não é mantido por tradição. Para que comportamentos sejam definidos como tradições, elas argumentam que uma dada variação comportamental deve ser comum a vários membros do grupo, deve ter uma longa duração e, principalmente, deve ser necessariamente mantida através da aprendizagem socialmente mediada. Portanto, o principal fator a ser identificado, no que concerne uma tradição, seria a influência social na aquisição individual do comportamento em questão. Para isso, é necessário, através de estudos de longo prazo, acompanhar o desenvolvimento e transmissão do comportamento em questão. Isto já foi realizado com macacos-prego em situação de semi-cativeiro (Resende, et al., no prelo). No entanto, sabemos da extrema dificuldade de se obter tais dados em estudos de campo em ambiente natural.

Entre os caiararas, Panger et al. (2002) encontraram diferenças nas técnicas de forrageamento extrativo entre diferentes grupos de Cebus capucinus. Embora não haja qualquer evidência de uso natural sistemático de ferramentas, Perry et al. (2003) mostram que há tradições comportamentais nessa espécie. Tais tradições ocorrem no contexto social (brincadeiras e gestos de contato).

\subsubsection{Aprendizagem Socialmente Mediada em Macacos-Prego}

Quanto à aprendizagem socialmente mediada em macacos-prego, pesquisas em laboratório apontam para a possibilidade de que tais animais aprendam por realce de estímulo e/ou de local (stimulus ou local enhancement) (Adams-Curtis \& Fragaszy, 1995; Resende, 1999), ou seja, um indivíduo tem sua atenção atraída para determinado objeto, aumentando sua interação com ele, quando ele vê um coespecífico interagindo com este objeto ou encontra as alterações ambientais decorrentes desta atividade manipulativa, mas não aprende "como" executar a tarefa a partir do exemplo de outro animal: a manipulação do objeto será desenvolvida por tentativa-e-erro. Fragaszy \& Visalberghi (1989), estudando animais cativos, mostram que macacos-prego não aprendem de imediato as relações instrumentais observando coespecíficos e que não ocorre imitação dos movimentos do indivíduo-modelo. No entanto, Custance et al. (1999) desenvolveram um experimento em que macacos-prego deveriam abrir um equipamento e concluíram que os sujeitos demonstraram formas mais complexas de 
aprendizagem social. A tarefa envolvia o teste de duas ações, em que cada um dos três componentes principais do equipamento poderia ser retirado de dois modos diferentes e apenas a demonstração de um modo era assistida pelo observador. Os autores verificaram que os observadores manipulavam o aparato de maneira semelhante ao que tinham observado o que é consistente com a hipótese de imitação.

Fredman \& Whiten (2008), também realizando experimentos envolvendo o teste de duas ações, verificaram que através do processo de realce de estímulo os macacosprego são capazes de receber informações sobre muitos aspectos precisos do objeto pelo qual são defrontados. Segundo os autores, se além do realce de estímulo, observar um coespecífico canaliza certos comportamentos específicos de um amplo repertório, então estes dois processos atuando juntos poderiam ter grande influencia na aprendizagem de novas habilidades de um macaco-prego em seu ambiente social.

Nove macacos-prego juvenis foram testados quanto à capacidade de adquirir habilidades do uso de ferramentas em dois contextos sociais diferentes (Fragaszy et al. 1994). Na primeira situação experimental eles observavam outro animal da mesma idade; na segunda, os juvenis se deparavam com a tarefa na companhia de sujeitos adultos (em sua maioria proficientes). Segundo os autores, os juvenis são estimulados a explorar quando na presença de adultos ativos, porém a coordenação da exploração junto aos adultos proficientes não estava relacionada à aprendizagem de novas habilidades.

\subsubsection{Tolerância Social, Partilha de Alimentos e Observação de Coespecíficos em Macacos-Prego}

Segundo Coussi-Korbel \& Fragaszy (1995), o contexto específico no qual um animal social se encontra (posição hierárquica, laços afiliativos, faixa etária, etc.) influencia suas oportunidades de aprendizagem social e, talvez, sua propensão para aprender certas coisas com determinados indivíduos. Sob este ponto de vista, torna-se importante considerar a interação entre os dois indivíduos e como ocorre a coordenação de seus comportamentos, que pode ou não envolver proximidade. Havendo proximidade, o observador tem melhores chances de adquirir informação detalhada sobre o comportamento do alvo de observação. Segundo as autoras, a identidade do alvo de observação pode ou não ser relevante para o observador. Em caso positivo, certos indivíduos serão modelos mais influentes sobre certos observadores do que outros, 
dependendo das relações sociais pré-existentes. Para que ocorra a aprendizagem socialmente mediada, é necessário que o estilo de dinâmica social permita a tolerância entre os membros do grupo.

Em espécies tolerantes como os macacos-prego, quando um indivíduo A tem em sua posse um item alimentar ele freqüentemente tolera a proximidade física de um indivíduo B (principalmente, mas não exclusivamente, se B for um infante ou juvenil). Indivíduos (especialmente sem comida) aproximam-se do indivíduo A e mostram interesse na comida e na atividade alimentar, observando e cheirando o alimento na posse do indivíduo A. Segundo Visalberghi \& Adessi (2003) a combinação "alimentoindivíduo A" - e possivelmente a atividade de A dirigida ao item alimentar - aumentam o interesse de B pela comida.

O grau de tolerância social determina quão próximo um animal pode observar a atividade de um coespecífico e, assim, a quantidade de detalhe que pode ser transmitida através de aprendizagem observacional (Coussi-Korbel \& Fragaszy, 1995). Estudos em ambiente natural têm mostrado que macacos-pregos exibem um alto grau de tolerância interindividual durante o contexto de alimentação, especialmente em relação a infantes e juvenis (Izawa, 1980; Izawa \& Mizuno, 1977; Janson, 1988, Perry \& Rose, 1994 com C. capucinus). Estes estudos relatam que infantes e juvenis parecem extremamente interessados nos itens alimentares que os adultos manipulam e obtém os restos que os adultos derrubam ou deixam para trás. Estes comportamentos parecem especialmente proeminentes quando o item alimentar é grande ou de difícil acesso (Fragaszy et al., 1997). Assim, a exploração tolerada de alimentos de outros pode ser uma estratégia para os infantes explorarem recursos que de outra maneira é impossível a eles.

É possível que indivíduos (especialmente infantes e juvenis) possam aprender sobre atividade alimentar de outros membros do grupo por cheirar de perto e/ou provar os itens alimentares que outros indivíduos consomem (Visalberghi \& Adessi, op cit.). Segundo as autoras, os comportamentos de cheirar e provar permitem uma influência social na aceitação do alimento. A partilha passiva de alimento pode, ainda, ser relevante na aquisição das preferências de dieta do infante (King, 1994 e Price \& Feistner, 1993 apud Fragaszy et al., 1997).

Fragaszy et al., (1997) forneceram a um grupo de macacos-prego cativos frutos encapsulados (castanhas) que requeriam manipulação complexa (sem o uso de ferramentas) e ração (que não requer nenhuma técnica de manipulação). Os infantes foram igualmente tolerados por outros indivíduos nas tentativas de partilha em ambas as 
condições. De acordo com os resultados, os infantes que não conseguiam abrir as castanhas por si sós mostraram maior interesse pelas castanhas do que pela ração. Os autores atribuíram tal diferença a uma maior preferência por castanhas pelos macacos ou à dificuldade relativa que os infantes têm em explorar os dois itens alimentares. Desta forma, os infantes de macacos-prego exibem meios comportamentais para explorar recursos de difícil acesso antes de serem capazes de realizar tal tarefa manipulativa por si sós, uma vez que são tolerados, obtendo o alimento de outros indivíduos.

Também em cativeiro, de Waal (1997 e 2000) demonstrou que macacos-prego, separados por uma grade, toleram a partilha de alimento. Mesmo quando o indivíduo que possui a comida pode monopolizá-la, há uma alta freqüência de partilha passiva com o outro indivíduo, ou seja, o indivíduo de posse do alimento permite que o outro também coma, mas não lhe transfere a comida diretamente.

Em ambiente natural, poucos primatas compartilham alimentos regularmente além do contexto mãe-filhote (de Waal, 2000). Os exemplos mais bem conhecidos na literatura são os bonobos (Pan paniscus) e chimpanzés (Pan troglodytes) que compartilham caça e frutos (de Waal, op cit).

A partilha de alimentos por macacos-prego selvagens é ainda pouco estudada. Em seus parentes mais próximos, os caiararas (Cebus capucinus), há relatos de partilha de pequenos mamíferos (quatis e esquilos) (Perry \& Rose, 1994; Rose, 1997). A partilha de itens alimentares encapsulados que exigem o uso de ferramentas para sua exploração ainda não foi estudada em macacos-prego em seu ambiente natural.

\subsubsection{Observação e Aprendizagem Socialmente Mediada na Quebra de Frutos Encapsulados}

Segundo Matsuzawa (1994), a quebra de cocos por chimpanzés envolve aprendizagem social. O autor relata que os filhotes observam os adultos, tendo sua atenção voltada para as ferramentas e os cocos, além de utilizarem as ferramentas deixadas pelos adultos.

A quebra de cocos por chimpanzés requer um longo tempo de aprendizagem. Em um estudo longitudinal de quatro anos, Inoue-Nakamura \& Matsuzawa (1997), descrevem a aquisição do comportamento de quebra de cocos pelos infantes (menores 
de 4 anos de idade). Com aproximadamente um ano de idade, os chimpanzés começaram a manipular cocos e pedras sozinhos (um objeto de cada vez). Por volta dos dois anos, passam a manipular os dois objetos de forma associada, mas apenas após os três, ou, para alguns indivíduos, os cinco anos de idade, passam a associar os três objetos (coco, bigorna e martelo) no arranjo temporal e espacial necessário para quebrar cocos. A proficiência de um adulto só é atingida pelos juvenis aos nove anos de idade.

Inoue-Nakamura \& Matsuzawa (1997) acreditam que os filhotes aprendem os objetivos a serem atingidos a partir da observação do uso das pedras pelos adultos, porém não observaram nenhum episódio de ensino pelos adultos. No entanto, há um (único) relato de uma mãe chimpanzé aparentemente ensinando a maneira correta de segurar o martelo à sua filha (Boesch, 1991).

Ottoni \& Mannu (2001), num estudo realizado com macacos-prego em semiliberdade, viram que os episódios de quebra de cocos permitiam uma situação propícia para a aprendizagem observacional. Cerca 17\% dos episódios foram observados por coespecíficos. Como em chimpanzés (Biro et al., 2003), os indivíduos observadores foram na maioria, mais jovens que os alvos.

Em outro estudo, com o mesmo grupo de animais, Resende \& Ottoni (2002) relatam que aproximadamente um quarto dos eventos de quebra de cocos registrados foi observado por outros indivíduos coespecíficos. Realizando análises detalhadas, os autores mostraram que existe uma escolha ativa dos alvos de observação, sugerindo que a proficiência na quebra é o fator levado em conta pelos observadores (Ottoni, et al., 2005). Novamente, os indivíduos observadores foram, na maioria, mais jovens que os coespecíficos-alvos.

A obtenção do endosperma do coco quebrado por outros (Scrounging) parece fornecer a explicação mais parcimoniosa para esse comportamento, uma vez que, ao observar indivíduos mais proficientes, o scrounger teria acesso a mais restos de coco. Uma vez que estes indivíduos mais jovens ainda não são capazes de processar frutos encapsulados com o auxílio de ferramentas, e que este recurso pode ser crítico em determinados ambientes (como a caatinga ou o cerrado), esta constituiria uma importante estratégia de forrageamento, tolerada pelos indivíduos mais velhos e proficientes. Entretanto, ao priorizar, como “alvos" de observação, os manipuladores de ferramentas mais proficientes, os jovens observadores concomitantemente otimizam suas oportunidades de aprendizagem social do uso de ferramentas (Ottoni et al., op cit.). 


\subsection{Objetivos}

No estudo realizado no Parque Ecológico do Tietê, onde o grupo de macacosprego recebe provisionamento diário, Ottoni et al. (2005) partiram de uma análise posthoc dos dados dos episódios de quebra de cocos registrados quanto à presença de observadores e suas correlações com diversos parâmetros relativos aos "alvos" potenciais de observação. Os resultados mostraram que a escolha do "alvo" não é aleatória, mas não é significativamente associada à proximidade social entre "observadores" e "alvos", nem à dominância do "alvo" ou sua idade (embora jovens macacos-prego mostrem um grande interesse pelas atividades de indivíduos mais dominantes, e os "alvos" sejam geralmente mais velhos que os "observadores"). Foi encontrada uma correlação significativa entre Observação e Proficiência (na quebra de $\operatorname{cocos}$ ) dos "alvos" potenciais. Estes resultados indicam, portanto, uma escolha ativa por parte dos observadores coespecíficos dos "alvos" de observação mais proficientes.

O presente estudo visa testar se algo semelhante ocorre em uma população selvagem, isto é, se há indicações de uma escolha ativa, pelos observadores coespecíficos, de determinados alvos de observação - e se esta escolha pode otimizar as oportunidades de Scrounging, uma vez que os jovens observadores tipicamente consomem parte do endosperma obtido pelos "alvos". Temos como objetivo examinar a proficiência dos manipuladores de ferramentas, o processo de escolha destes manipuladores como "alvos" pelos observadores coespecífico e as taxas efetivas de Scrounging nos episódios com e sem observação da quebra de cocos em uma população selvagem.

Examinaremos também outras formas de partilha de alimento fora dos episódios de quebra de cocos, correlacionando-as com as idades/sexos dos doadores e receptores e as relações de proximidade entre os indivíduos envolvidos, comparando ainda essa forma de partilha com o Scrounging de cocos.

Por fim, este estudo em ambiente natural visa contribuir para análises comparativas com um novo estudo em andamento, sendo realizado concomitantemente pelo Laboratório de Etologia Cognitiva com o mesmo grupo aprovisionado anteriormente estudado no Parque Ecológico do Tietê, SP utilizando um protocolo semelhante. 


\section{Material e Métodos}

\subsection{Local: Fazenda Boa Vista}

A Fazenda Boa Vista (BV) está localizada numa região de ecótono cerrado/caatinga pertencente ao município de Gilbués, sudeste do estado do Piauí, nas coordenadas $9^{\circ} 49^{\prime} 55^{\prime}$ ' S e $45^{\circ} 20^{\prime} 38^{\prime}$ ' W. O local de estudo, propriedade de Marino Oliveira (M.O.), tem aproximadamente 1.250 ha e é conhecido pela nossa equipe desde setembro de 2003, quando Fragaszy, Izar e Visalberghi, com o apoio de M. O., realizaram um estudo descritivo do uso de ferramentas pelos macacos-prego da região (Fragaszy et al. 2004b). A área é formada por uma planície limitada por escarpas e "mesas" de arenito que se erguem até mais de $30 \mathrm{~m}$ de altura. A fitofisionomia do local é variada, sendo composta por planícies e morros de arenito

As planícies são formadas por chapadas e brejos: as chapadas cobrem a maior parte das áreas planas, são caracterizadas por predomínio de árvores de médio porte como sapucaia (Eschweilera nana), pequi (Caryocar brasiliense) e jatobá (Hymenaea courbaril) e abundância de palmeiras rasteiras, além de forrageiras exóticas; os brejos são caracterizados pela maior diversidade de árvores de médio porte formando matas ciliares (florestas de galeria) e os buritizais (Mauritia flexuosa), e pela presença de pequenas lagoas e cursos d'agua.

Nos morros de arenito há basicamente dois tipos de paisagem: as encostas, onde se observam arbustos e árvores de pequeno e médio porte, como mandioca brava (Euphorbiaceae) e faveira (Parkia pendula) e baixa densidade de palmeiras; e os topos, caracterizados por vegetação herbácea e arbustiva e algumas espécies de bromeliáceas e cactáceas.

A área apresenta sazonalidade marcada quanto ao regime de chuvas, sendo possível definir duas estações bem distintas: uma estação seca (de maio a setembro, com precipitação média de $10 \mathrm{~mm}$ ) e uma estação chuvosa (de outubro a abril, com precipitação média de $155 \mathrm{~mm})^{1}$.

As diversas espécies de palmeiras (Astrocharyum sp., Syagrus sp., Orbygnia sp. e outras não-identificadas) são abundantes, principalmente nas áreas de chapada (Fragaszy et al., dados não publicados). As espécies de palmeiras desta área têm caules subterrâneos curtos, as frondes e os cachos de frutos emergem do solo. Os macacos-

${ }^{1}$ Média de precipitação no município de Gilbués, PI, entre 1971 e 1990. Dados Embrapa: banco de dados climáticos do Brasil 
prego utilizam ferramentas para abrir o duro endocarpo e ter acesso ao endosperma ou, mais raramente, às larvas de coleópteros ("gongo") nele contidas. Além disso, os macacos se alimentam da polpa do coco e do endosperma ainda em forma líquida (água do coco).

A fauna local contém muitas espécies de répteis, tais como teiú (Tupinambis sp.), jararaca (Bothrops sp.), jibóia (Boa constrictor) e pequenos lagartos; aves como anhuma (Anhima cornuta), arara-vermelha (Ara chloropterus), pica-pau-de-bandabranca (Dryocopus lineatus ); mamíferos como onça parda (Puma concolor), tamanduámirim (Tamandua tetradactyla), tatupeba (Euphractus sexcinctus).

Na propriedade existe um "esconderijo" construído em frente a um dos sítios de quebra habitualmente utilizado pelos macacos do "Grupo do Chicão" (GC), que foi acompanhado por outros pesquisadores (Michele P. Verderane e Noemi Spagnoletti). O sítio contém várias pedras utilizadas como "martelos" e blocos de arenito e troncos de árvores utilizados como "bigornas" na quebra de cocos. Cocos das espécies nativas de palmeiras têm sido fornecidos diariamente no local nos últimos cinco anos. $\mathrm{O}$ esconderijo foi construído e o provisionamento, levado a cabo, para viabilizar o ecoturismo no local, administrado em parceria com a ONG BioBrasil.

\subsection{Sujeitos}

O grupo aqui estudado, "Grupo do Zangado" (GZ), anteriormente conhecido por "Grupo Ouro Preto", sofreu uma divisão não acompanhada pelo pesquisador. Quando iniciamos a pesquisa, o grupo já havia sido habituado à presença humana por M.O. e seu filho M.O. Júnior. Esta pesquisa foi feita com o GZ por se tratar de um grupo selvagem, não provisionado, onde o comportamento não sofre a influência de uma dieta adicional (inclusive o uso de ferramentas para quebra de itens alimentares encapsulados), para que possamos comparar nossos resultados com outros estudos realizados com grupos de macacos-prego provisionados. O GZ não visitou o esconderijo (descrito acima) durante o período de coleta. $\mathrm{O}$ número de indivíduos do grupo variou de 14 a 8 . A Tabela 1 apresenta a composição do grupo durante todo o período de coleta de dados, incluindo os sujeitos, o sexo e a faixa etária. As faixas etárias foram determinadas da seguinte maneira: 
- Infantes: do nascimento até o desmame. No entanto, existe grande variabilidade na idade de desmame entre os diferentes filhotes de um grupo, o que pode ser influenciado pelo estilo de vida de cada mãe, pela disponibilidade de alimento e, em algumas espécies (não sabemos ainda se é o caso dos macacos-prego), pelo sexo dos filhotes. Os poucos trabalhos na literatura que falam sobre a idade do desmame para o gênero Cebus indicam que essa idade varia, em média, entre 16 e 20,5 meses (Verderane, comunicação pessoal; Weaver, 1999 apud Fragaszy et al., 2004a). Os indivíduos desta idade são facilmente identificáveis devido ao tamanho e à proximidade com a mãe.

- Juvenis: indivíduos imaturos com uma maior autonomia. Machos: da independência até aproximadamente os cinco anos, quando o indivíduo adquire tamanho corporal de adulto. Fêmeas: desde o desmame até a maturidade sexual. Calculamos o início da maturidade sexual das fêmeas diminuindo 155 dias, período estimado de gestação (Hartwig, 1996 apud Fragaszy et al., 2004a), da data de nascimento do primeiro filhote.

- Subadultos: nesta faixa etária foram incluídos os machos que não atingiram o desenvolvimento corporal e comportamental pleno característico do adulto. Possuem tamanho de adulto, mas com topete e barba pouco desenvolvidos (idade estimada entre cinco e sete anos).

- Adultos: foram considerados adultos os machos que apresentam topete e barba bem desenvolvidos característicos da espécie (mais de sete anos) e fêmeas reprodutivas (faixa etária atingida por volta de cinco anos de idade).

Não havendo informações sobre a idade cronológica dos indivíduos, exceto dos infantes nascidos durante o acompanhamento do grupo, foram utilizadas apenas as características morfológicas e comportamentais na determinação das faixas etárias. 
Tabela 1: Nome, sigla, sexo, faixa etária e presença dos sujeitos no grupo estudado ao longo do período de coleta de dados - maio de 2006 até abril de 2007 (os períodos serão definidos adiante). M: Macho; F: Fêmea; A: Adulto; S: Subadulto; J: Jovem; I: Infante; x/x: mudança de faixa etária ao longo da coleta de dados. $\Delta$ : nascimento; $\uparrow:$ óbito; $\rightarrow$ : saída do grupo (migração). P1: Primeiro Período; P2: Segundo Período; P3: Terceiro Período.

\begin{tabular}{|c|c|c|c|c|c|c|c|c|c|c|c|c|c|c|c|}
\hline \multirow[b]{2}{*}{ Nome } & \multirow[b]{2}{*}{ Sigla } & \multirow[b]{2}{*}{ Sexo } & \multirow[b]{2}{*}{$\begin{array}{c}\text { Faixa } \\
\text { Etária }\end{array}$} & \multicolumn{2}{|c|}{ P1 } & \multirow{2}{*}{$\begin{array}{c}\mathbf{P 2} \\
\mathrm{J}\end{array}$} & \multicolumn{9}{|c|}{ P3 } \\
\hline & & & & $\mathbf{M}$ & $\mathbf{J}$ & & A & S & $\mathbf{O}$ & $\mathbf{N}$ & D & $\mathbf{J}$ & $\mathbf{F}$ & $\mathbf{M}$ & A \\
\hline Zangado & Zan & $\mathbf{M}$ & A & $\mathrm{x}$ & $\mathrm{x}$ & $\mathrm{x}$ & $\mathrm{X}$ & $\mathrm{x}$ & $\mathrm{x}$ & $\mathrm{x}$ & $\mathrm{x}$ & $\mathrm{x}$ & $\mathrm{x}$ & $\mathrm{x}$ & $\mathrm{X}$ \\
\hline Moça Branca & Mob & $\mathbf{F}$ & A & $\mathrm{x}$ & $\mathrm{x}$ & $\mathrm{x}$ & $\mathrm{x}$ & $\mathrm{x}$ & $\mathrm{x}$ & $\mathrm{x}$ & $\mathrm{x}$ & $\mathrm{x}$ & $\mathrm{x}$ & $\mathrm{x}$ & $\mathrm{x}$ \\
\hline Emília & Ema & $\mathbf{F}$ & A & $\mathrm{x}$ & $\mathrm{x}$ & $\mathrm{x}$ & $\mathrm{X}$ & $\mathrm{x}$ & $\mathrm{x}$ & $\mathrm{x}$ & $\mathrm{x}$ & $\mathrm{x}$ & $\mathrm{x}$ & $\mathrm{x}$ & $\mathrm{x}$ \\
\hline Pretinha & Pra & $\mathbf{F}$ & $\mathbf{A}$ & $\dagger$ & & & & & & & & & & & \\
\hline Dengoso & Den & $\mathbf{M}$ & $\mathbf{S}$ & $\mathrm{x}$ & $\mathrm{x}$ & $\mathrm{x}$ & $\rightarrow$ & & & & & & & & \\
\hline Mansinho & Man & $\mathbf{M}$ & $\mathbf{S}$ & $\mathrm{x}$ & $\mathrm{x}$ & $\rightarrow$ & & & & & & & & & \\
\hline Teimoso & Tei & $\mathbf{M}$ & $\mathbf{J}$ & $\mathrm{x}$ & $\mathrm{x}$ & $\rightarrow$ & & & & & & & & & \\
\hline Jatobá & Jat & $\mathbf{M}$ & $\mathbf{J}$ & $\mathrm{x}$ & $\mathrm{x}$ & $\rightarrow$ & & & & & & & & & \\
\hline Moça Chita & Moc & $\mathbf{F}$ & A & $\mathrm{x}$ & $\mathrm{x}$ & $\mathrm{x}$ & $\mathrm{x}$ & $\mathrm{x}$ & $\mathrm{x}$ & $\mathrm{x}$ & $\mathrm{x}$ & $\mathrm{x}$ & $\mathrm{x}$ & $\mathrm{x}$ & $\mathrm{x}$ \\
\hline Dunga & Dun & $\mathbf{F}$ & $\mathbf{J}$ & $\mathrm{x}$ & $\mathrm{x}$ & $\mathrm{x}$ & $\mathrm{x}$ & $\mathrm{x}$ & $\mathrm{x}$ & $\mathrm{x}$ & $\mathrm{x}$ & $\mathrm{x}$ & $\mathrm{x}$ & $\mathrm{x}$ & $\mathrm{x}$ \\
\hline Catuaba & Cat & $\mathbf{F}$ & $\mathbf{J}$ & $\mathrm{x}$ & $\mathrm{x}$ & $\mathrm{x}$ & $\mathrm{x}$ & $\mathrm{x}$ & $\mathrm{x}$ & $\mathrm{x}$ & $\mathrm{x}$ & $\mathrm{x}$ & $\mathrm{x}$ & $\mathrm{x}$ & $\mathrm{x}$ \\
\hline Kico & Kic & $\mathbf{M}$ & I & $\mathrm{x}$ & $\mathrm{x}$ & $\mathrm{x}$ & $\mathrm{x}$ & $\mathrm{x}$ & $\mathrm{x}$ & $\mathrm{x}$ & $\mathrm{x}$ & $\mathrm{x}$ & $\mathrm{x}$ & $\mathrm{x}$ & $\mathrm{x}$ \\
\hline Ervilha & Eva & $\mathbf{F}$ & I & $\mathrm{x}$ & $\mathrm{x}$ & $\mathrm{x}$ & $\mathrm{x}$ & $\mathrm{x}$ & $\mathrm{x}$ & $\mathrm{x}$ & $\mathrm{x}$ & $\mathrm{x}$ & $\mathrm{x}$ & $\mathrm{x}$ & $\mathrm{x}$ \\
\hline Pretinho & Pro & $\mathbf{M}$ & I & $\dagger$ & & & & & & & & & & & \\
\hline Café & Caf & $?$ & I & & & & & & & & $\Delta$ & $\mathrm{x}$ & $\mathrm{x}$ & $\mathrm{x}$ & $\mathrm{x}$ \\
\hline Elisa & Ela & $?$ & I & & & & & & & & & & & $\Delta$ & $\mathrm{x}$ \\
\hline
\end{tabular}




\subsection{Coleta de Dados}

Em fevereiro de 2006 foi iniciada a habituação do grupo ao pesquisador e o reconhecimento dos indivíduos. A coleta de dados foi realizada de maio de 2006 a abril de 2007. Em média, foram feitos 10 dias de observação por mês em que o grupo era acompanhado do amanhecer (ou quando o grupo era encontrado) até o anoitecer, quando o grupo já se encontrava em seu local de dormida (ou quando perdíamos contato com o grupo).

Foram realizadas 999 horas de observação em 1.350 horas de campo.

Empregamos os seguintes métodos de amostragem (Altman, 1974; Martin \& Bateson, 1993):

- Varredura Focal: Tendo uma seqüência previamente determinada e aleatória de indivíduos focais, foi feito o registro de todos os animais que estavam em contato, a $1 \mathrm{~m}$, a $5 \mathrm{~m}$ e a $10 \mathrm{~m}$ do sujeito focal, com espaçamento de um minuto entre as amostras. Este método de amostragem possibilitou a construção de Árvores Geradoras Mínimas (AGM), que nos fornecem uma representação gráfica das relações sociais mais fortes entre pares de indivíduos do grupo. As arestas indicam as distâncias entre os indivíduos, ou seja, se a aresta é grande, os indivíduos estão distantes (Resende, 1999; Izar et al., 2005). Assim quantificamos a relação de proximidade entre os membros do grupo, e obtivemos o índice de Jaccard, o que possibilitou realizarmos correlações entre a proximidade dos indivíduos durante as diversas atividades diárias do grupo e a Quebra de Cocos.

- Todas as Ocorrências de Partilha de Alimento: Todos os episódios de partilha de alimento foram registrados. Um episódio de partilha tinha início quando um indivíduo se aproximava de outro tendo um deles alimento em sua posse. O fim do episódio se dava quando um dos indivíduos se afastava a uma distância igual ou superior a $2 \mathrm{~m}$, ou quando o alimento tivesse sido totalmente ingerido ou eliminado. Foi anotado o item alimentar explorado pelos sujeitos, assim como os indivíduos participantes do evento de partilha. O indivíduo com alimento em sua posse foi denominado doador e o que toma o item alimentar, de receptor. Quanto à ação do receptor, denominamos os episódios como "partilha direta" quando este pega o alimento das mãos, pés, boca ou qualquer outra parte do corpo do doador; com "partilha indireta", quando o receptor pega imediatamente o alimento deixado pelo 
doador ou quando este deixa o item alimentar cair, mas permanece a uma distância de 2 metros.

\subsubsection{Registros dos episódios de quebra de cocos}

Os locais onde os macacos efetuam a quebra de cocos são chamamos de "sítio de quebra" (Mannu, 2002). Definimos como "bigorna" a superfície onde o macaco posiciona o coco (ou outro item alimentar); esta poderia ser uma pedra ou tronco (ver Visalberghi et al., 2007). Usamos o termo "martelo" para indicar a pedra usada para golpear o coco.

- "Evento Focal": No início, tínhamos o objetivo de filmar todos os eventos de quebra de cocos; no entanto, devido à dificuldade de locomoção e visibilidade na vegetação em que se encontram grande parte dos sítios de quebra, adotamos um protocolo para anotar os dados diretamente no local. Optamos por um procedimento em que o primeiro evento de quebra detectado pelo pesquisador foi sempre acompanhado até o final. Já que episódios simultâneos deixam de ser observados (ao menos com o mesmo nível de detalhamento), o procedimento proposto se distingue de um "Todas as Ocorrências" convencional, razão pela qual adotamos o rótulo de "Evento Focal".

Foi definido como início de um episódio de quebra o posicionamento, por um macaco, de um coco (ou outro item) sobre uma bigorna ou quando o indivíduo golpeia com o martelo um coco já posicionado. O episódio de quebra foi considerado findo quando o sujeito cessava os golpes contra a bigorna e se afastava do sítio por mais de 30 segundos e - quando havia um ou mais observadores - quando estes também se afastavam do sítio pelo mesmo período.

A categoria comportamental "Quebra de Cocos" foi dividida em quatro subcategorias conforme o desempenho e/ou o resultado da atividade:

- Quebra Adequada (QA): eventos em que o sujeito posiciona e golpeia o coco (ou fruto encapsulado) "adequadamente", mas não consegue romper a parte dura (endocarpo), não tendo acesso ao alimento.

- Quebra Proficiente (QP): quando houve o rompimento da casca e o acesso ao endosperma.

- Quebra Inepta (QI): indivíduo posiciona um objeto inadequado na bigorna, ou usa martelos e/ou bigornas de forma inadequada, desordenada, ou seja, de forma ineficiente para que o coco (ou outro item alimentar) seja quebrado. 
- Quebra Não-determinada (QN): quando não for possível registrar se houve ou não sucesso na quebra.

Quando nos referimos a um indivíduo como "quebrador", estamos nos referindo a um macaco que efetuava qualquer destas categorias de quebra de cocos listadas acima, sendo ele "alvo" apenas quando era observado, durante o episódio de quebra, por outro indivíduo.

Para cada Evento Focal registramos a data, o horário, a duração do episódio, a quantidade e identificação do material quebrado (coco ou outro), a categoria do evento (QP, QA, QI, QN), a presença de observadores coespecíficos (posicionados a no máximo um metro e com olhar voltado para a ação) e os indivíduos que coletavam restos (scroungers) durante a quebra (Scrounging Imediato) ou sobras deixadas com a saída do quebrador (Scrounging Mediato). Também coletamos dados relativos à manipulação dos elementos do sítio pelo observador-scrounger, tanto na presença quanto na ausência do quebrador.

Para a coleta de dados, utilizamos o etograma da Tabela 2. Quantificamos as atividades dos sujeitos na quebra de cocos, anotando os comportamentos em intervalos de 10 segundos (conforme o Etograma), possibilitando comparações entre as atividades dos alvos e os comportamentos manipulativos realizados pelo observador e/ou scrounger na presença e na ausência do quebrador. 
Tabela 2: Etograma utilizado nos registros pelo método do "Evento Focal".

\begin{tabular}{|l|l|}
\hline Categoria & Descrição \\
\hline Chegar ao sítio & Aproximar-se da bigorna. \\
\hline Deixar o sítio & Afastar-se da bigorna. \\
\hline Quebrar coco & $\begin{array}{l}\text { Quebra Proficiente, Quebra Adequada, Quebra Inepta ou Quebra Não- } \\
\text { determinada (definidos na página anterior). }\end{array}$ \\
\hline Manipular pedra & $\begin{array}{l}\text { Pegar pedra com as mãos e executar comportamentos como bater ou } \\
\text { esfregá-la na bigorna. }\end{array}$ \\
\hline Manipular coco & $\begin{array}{l}\text { Executar atividades como bater, esfregar ou posicionar o coco (ou outro } \\
\text { fruto encapsulado) na bigorna. }\end{array}$ \\
\hline Transportar coco & $\begin{array}{l}\text { Deslocar-se de um lugar a outro carregando coco (ou outro fruto } \\
\text { encapsulado) por distância superior a um metro. }\end{array}$ \\
\hline Transportar pedra & $\begin{array}{l}\text { Deslocar-se de um lugar a outro carregando pedra por distância superior } \\
\text { a um metro. }\end{array}$ \\
\hline Ingerir endosperma & $\begin{array}{l}\text { Levar pedaços de endosperma do coco (ou outro fruto encapsulado) à } \\
\text { boca engolindo em seguida, ou engolir líquido. }\end{array}$ \\
\hline Ingerir outros & $\begin{array}{l}\text { Levar qualquer outro item alimentar a boca engolindo em seguida, } \\
\text { inclusive polpa (mesocarpo) de cocos (ou outro fruto encapsulado). }\end{array}$ \\
\hline Inspecionar & $\begin{array}{l}\text { Examinar visualmente, cheirar e/ou levar cocos (ou outro fruto } \\
\text { encapsulado) à boca, sem que ocorra sua ingestão. }\end{array}$ \\
\hline Gestos empáticos & $\begin{array}{l}\text { Executar (observador) movimentos semelhantes aos do manipulador, } \\
\text { porém sem nenhum objeto em mãos. }\end{array}$ \\
\hline Interação social & $\begin{array}{l}\text { Qualquer interação social ocorrendo durante o Evento de Quebra, seja } \\
\text { agonística ou não. }\end{array}$ \\
\hline
\end{tabular}

Ao final de um Evento de quebra de cocos, utilizamos os seguintes critérios para escolha do próximo evento a ser acompanhado: (1) se houvesse outros eventos em andamento quando o primeiro acabasse, começávamos com o que estivesse ocorrendo à menor distância do pesquisador; (2) se dois ou mais eventos de quebra começassem simultaneamente privilegiávamos o evento com o manipulador menos recentemente observado pelo pesquisador.

Foi registrado o tempo de manipulação pelo alvo, o número de cocos posicionados, quebrados e ingeridos e o número de golpes necessário para quebrar cada coco. Na presença de observadores coespecíficos, registrou-se o tempo em que o indivíduo ficou engajado na observação e se houve scrounging. As atividades do observador foram analisadas na presença 
e na ausência do "alvo" (quando este sai para buscar outro coco, por exemplo), para podermos avaliar o nível de tolerância dos alvos em relação aos observadores.

Por este método, pudemos quantificar a proficiência na quebra de cocos pelos quebradores (sendo eles "alvos" ou não) e as taxas efetivas de scrounging dos observadores, ou seja, em quantos eventos eles realmente ingerem restos do coco (na presença e na ausência do quebrador), nos episódios de quebra do começo ao fim.

A coleta de dados foi realizada de forma a se obter o registro comportamental dos sujeitos do amanhecer ao anoitecer, nas diferentes épocas do ano, possibilitando analisar a relevância do scrounging na dieta dos indivíduos (principalmente infantes e juvenis), ou seja, quanto os indivíduos mais jovens dependem do alimento encapsulado processado por outros sujeitos, e as interações sociais das quais os sujeitos participam.

Quanto às características físicas dos sítios de quebra, registramos o peso do martelo, o material da bigorna (pedra, madeira, árvore, caverna), a cobertura vegetal do sítio (alta, média, baixa) e o tipo de ambiente (chapada, grota, encosta, morro).

- Todas as Ocorrências de Quebra de Cocos (ou outros): No caso de haver outros episódios de quebra simultâneos aos Eventos Focais, ou executados em local de difícil acesso/visualização, estes foram registrados segundo um procedimento de amostragem de Todas as Ocorrências, com o máximo detalhamento possível. Assim, com o auxílio de outros pesquisadores e dos ajudantes de campo (Jozemar Oliveira e Arizomar Oliveira) registrava-se quem tentava quebrar o coco, o resultado da tentativa de quebra e os macacos que observavam a quebra, além da descrição dos elementos do sítio. Anotamos também, por este método, os eventos de uso de ferramentas para a quebra de outros frutos e sementes que os macacos incluíram na dieta.

Os episódios em que não foi possível registrar algum detalhe quantitativo essencial listado acima foram descartados da análise, sendo incluídos apenas no cálculo do índice de freqüência absoluta de Quebra de Cocos pelo grupo ou para descrições qualitativas do contexto de quebra. 


\subsection{Análise de Dados}

\subsubsection{A Quebra de Cocos}

Decidimos dividir nossa amostra em três períodos para análise do comportamento de quebra de cocos, por julgarmos certos acontecimentos no grupo de grande importância para nossos objetivos. No final do segundo mês de coleta de dados quatro machos - dois subadultos: Dengoso e Mansinho e dois juvenis: Jatobá e Teimoso - iniciaram a migração para outro grupo. Todos esses indivíduos eram proficientes na quebra de cocos e "alvos" de observação em potencial (como veremos). Portanto, a saída destes sujeitos afeta a dinâmica da quebra de cocos no grupo, além da disponibilidade de "alvos" de observação em potencial. Em julho de 2006 Dengoso ainda permanecia no grupo, mesmo que temporariamente. Portanto, nosso período amostral foi divido da seguinte maneira:

- P1: maio e junho de 2006 - do início da coleta até a migração de Mansinho, Teimoso e Jatobá;

- P2: julho de 2006 - até a migração de Dengoso para o Grupo do Chicão;

- P3: agosto de 2006 a abril de 2007 - até o final da coleta.

Como a fêmea adulta Pretinha e seu filhote Pretinho morreram logo no início da coleta (último avistamento dia 11 de maio de 2006) e não apresentaram o comportamento de quebra, esses indivíduos foram excluídos das análises. Pelo mesmo motivo - a ausência do envolvimento com a quebra de cocos - também não incluímos nas análises os infantes Café e Elisa.

Utilizamos os métodos de Evento Focal e Todas as Ocorrências para as análises sobre a demografia, a proficiência e a produtividade da quebra no Grupo de Zangado. Para isso, usamos as taxas: Taxa de Proficiência - obtida através da divisão do total de episódios proficientes $(\mathrm{QP})$, pela freqüência absoluta de episódios de quebra $(\mathrm{QP}+\mathrm{QA}+\mathrm{QI})$; Taxa de Produtividade - calculada dividindo-se a quantidade total de cocos quebrados por cada indivíduo pela freqüência absoluta de episódios de quebra de cada sujeito. 
Para as análises de proficiência e produtividade (ver abaixo) utilizamos apenas os episódios em que foi possível quantificar o número de cocos quebrados pelos sujeitos. Identificamos, assim, as características individuais do comportamento de uso de ferramentas para a quebra de cocos. Em alguns casos, devido ao baixo número de indivíduos, não foi possível realizar testes estatísticos. Quando possível, utilizamos o teste de Mann-Whitney (pelo programa BioEstast 3.0) para verificarmos se os indivíduos de diferentes faixas etárias e sexo desempenhavam a quebra com freqüência, proficiência e produtividade semelhantes.

Para averiguar as características da observação a alvos coespecíficos no contexto da quebra de cocos foram construídas tabelas contendo observadores nas linhas e alvos nas colunas. Realizamos, quando possível, o Teste de Mann-Whitney para saber se os indivíduos de sexo e faixa etária diferentes foram observados e observaram a quebra de cocos numa freqüência espera pelo acaso. Aqui também foram usados os dados coletados pelo método do Evento Focal e de Todas as Ocorrências, excluindo os episódios em que não foi possível quantificar o número exato de cocos quebrados pelos sujeitos.

Utilizamos somente os dados do Evento Focal para uma análise mais detalhada e consistente do scrounging entre os indivíduos durante os episódios de quebra de cocos, já que estes eventos foram acompanhados até o fim e o pesquisador permanecia no sítio até o sujeito quebrador se afastar por mais de 30 segundos, evitando assim a perda dos episódios em que o scrounger ingeria endosperma do coco deixado no sítio pelo quebrador (Scrounging Mediato) quando este se afastava da bigorna (estes episódios seriam subestimados pelo método de Todas as Ocorrências). Os dados dos Eventos Focais também foram utilizados para descrição dos comportamentos manipulativos do observador quando na presença ou na ausência do coespecífico alvo.

Os dados coletados por Varredura Focal, utilizados para análise da proximidade entre os membros do grupo, não se limitaram aos episódios de quebra de cocos, incluindo comportamentos como locomoção, descanso, forrageamento e brincadeira. A partir desses dados foi construída uma matriz de distância entre os indivíduos para cada período (v. acima). Como medida de distância, utilizamos o índice de Jaccard.

Utilizamos as Árvores Geradoras Mínimas (AGMs) apenas como ferramenta para uma melhor visualização das relações de proximidade mais fortes entre os pares de indivíduos do grupo em estudo. As AGMs resultam de uma análise baseada na Teoria dos Grafos, onde as arestas indicam as distâncias entre os indivíduos, ou seja, quanto maior é a aresta, mais 
distantes estão os indivíduos da díade (Izar et al., 2005). Estas árvores destacam apenas a relação mais forte para cada indivíduo; assim, se o sujeito A está ligado a B e a C, isto significa que B e C tiveram os valores mais baixos de distância em relação a A. A árvore não permite mostrar a distância entre B e C se esta for maior que a distância entre A e B e A e C.

\subsubsection{Escolha do Alvo}

Em primeiro lugar, para testar se a escolha dos alvos de observação pelos animais estava diretamente relacionada à proximidade e à tolerância social entre os indivíduos envolvidos, foi construída uma matriz assimétrica de Observação da Quebra (obtida através dos dados de Evento Focal e Todas as Ocorrências), em que os indivíduos-alvo eram posicionados nas colunas e os observadores nas linhas, e uma matriz simétrica de Proximidade (construída com os valores dos índices de Jaccard). Essas matrizes foram correlacionadas através do cálculo do Tau Kr (Hemelrijk, 1990a; Hemelrijk, 1990b).

Em seguida, para averiguar quais características dos indivíduos estariam associadas à sua escolha como alvos de observação, correlacionamos a matriz de Observação da Quebra, através do cálculo Tau Kr (Hemelrijk, op cit.), com matrizes hipotéticas das variáveis que julgamos relevantes, além de já relacionadas em trabalhos anteriores com o grupo do Parque Ecológico do Tietê (Ottoni et al., 2005). Essas matrizes hipotéticas são assim chamadas porque os valores das caselas são os valores referentes às colunas (os alvos de observação), ou seja, não são referentes às relações entre as díades. Esses cálculos foram feitos utilizando uma terceira matriz (“dummy”) para eliminar os possíveis efeitos de zeros estruturais (Hemelrijk, 1990b) que correspondem aos indivíduos impossíveis de serem alvos de observação, já que não houve registros do comportamento de quebra para estes indivíduos nos períodos relacionados $^{2}$. No primeiro período foram considerados zeros estruturais a infante Ervilha e o infante Kico e no segundo período a fêmea adulta Emilha, além dos infantes já citados. Foram usadas as seguintes matrizes hipotéticas:

- Postos Hierárquicos: Utilizamos os dados de Verderane (em preparação), que realizou um estudo no mesmo período sobre as relações sociais do grupo em questão, para a construção da matriz hipotética de postos hierárquicos.

- Freqüência de Quebra: Construímos essa matriz com a Freqüência Absoluta dos episódios de quebra de cocos por indivíduo em cada período da coleta de dados.

\footnotetext{
${ }^{2}$ No terceiro período não utilizamos uma terceira matriz "dummy" como controle, pois todos os indivíduos do grupo foram vistos utilizando ferramentas para a quebra de cocos (assim não houve sujeitos a serem considerados zeros estruturais).
} 
- Taxa de Proficiência na Quebra: Matriz indicando, para cada sujeito, o número de episódios em que o indivíduo obteve sucesso na quebra (independente do número de cocos quebrados por episódio), dividido pela Freqüência Absoluta de Quebra.

- Taxa de Produtividade na Quebra: esta Taxa foi calculada dividindo-se a quantidade total de cocos quebrados para cada indivíduo pela Freqüência Absoluta de episódios de quebra de cada sujeito.

Para calcular tais correlações pelo método do Tau Kr, utilizamos o programa MatrixtesterPrj, de Hemelrijk, op cit.

\subsubsection{Outros Itens Alimentares Encapsulados}

Utilizamos os dados coletados pelos métodos do Evento Focal e de Todas as Ocorrências para análise da quebra de outros itens alimentares encapsulados (não incluindo cocos). Comparamos as Taxas de Observação e Scrounging para estes ítens com as taxas correspondentes no contexto da quebra de cocos pelo cálculo do Qui-Quadrado. Realizamos análises semelhantes às descritas para a quebra de cocos (acima) e quando possível realizamos o Teste de Mann-Whitney para verificarmos se os indivíduos de diferentes faixas etárias e sexo desempenhavam a quebra com freqüência, proficiência e produtividade semelhantes. Para análise do comportamento de quebra destes outros itens alimentares, dividimos a coleta de dados em apenas dois períodos, unindo os períodos P2 e P3 (acima) em apenas um período, portanto: $\mathrm{P} 1$ = maio e junho de 2006 e P2+P3 = de julho de 2006 a abril de 2007, devido ao baixo número de episódios de quebra destes itens e o não-envolvimento de Dengoso nesta atividade no segundo período (julho de 2006).

\subsubsection{Partilha de Alimento}

Através dos dados obtidos pelo método de Todas as Ocorrências, analisamos a Partilha de Alimento para o "Grupo de Zangado": foram descritos os itens alimentares partilhados, assim como a demografia da partilha, de maio de 2006 a agosto de 2007. Para esta análise a coleta de dados foi dividida em dois períodos: $\mathrm{P} 1=$ maio e junho de 2006 e P2+P3 = julho de 2006 a abril de 2007 (ver acima). Quando possível utilizamos o teste de Mann-Whitney para comparar as freqüências em que os indivíduos em cada categoria de sexo e faixa etária 
atuaram como doadores e receptores na partilha. As correlações entre matrizes foram feitas através do cálculo Tau Kr (Hemelrijk, op cit.). 


\section{Resultados}

\subsection{A Quebra de Cocos}

\subsubsection{Demografia da Quebra de Cocos}

A Tabela 3 mostra os episódios de quebra de cocos registrados entre maio de 2006 e abril de 2007 amostrados pelos métodos do Evento Focal e de Todas as Ocorrências. Ela lista a freqüência dos episódios de quebra para cada sujeito, discriminando sexo, faixa etária e a freqüência absoluta com que desempenharam a quebra nos três períodos de coleta de coleta de dados.

Tabela 3: Macacos do Grupo do Zangado que apresentaram o comportamento de quebra de cocos (Adequada + Inepta + Proficiente + Não determinada), sua idade, sexo e número de episódios de quebra para todo o período de coleta de dados. M: Machos; F: Fêmeas; A: Adultos; S: Subadultos; J: Juvenis; I: Infantes; *: indivíduo ausente do grupo; P1: maio e junho de 2006; P2: julho de 2006; P3: agosto de 2006 a abril de 2007.

\begin{tabular}{|c|c|c|c|c|c|c|}
\hline \multirow[b]{2}{*}{ Indivíduo } & \multirow[b]{2}{*}{ Sexo } & \multirow[b]{2}{*}{$\begin{array}{l}\text { Faixa } \\
\text { etária }\end{array}$} & \multicolumn{4}{|c|}{$\begin{array}{c}\text { Episódios de Quebra } \\
\text { Evento Focal + Todas as Ocorrências }\end{array}$} \\
\hline & & & P1 & P2 & P3 & Total \\
\hline Zan & $\mathrm{M}$ & $\mathrm{A}$ & 81 & 33 & 107 & 221 \\
\hline Mob & $\mathrm{F}$ & A & 2 & 7 & 9 & 18 \\
\hline Ema & $\mathrm{F}$ & $\mathrm{A}$ & 1 & 0 & 5 & 6 \\
\hline Den & $\mathrm{M}$ & $\mathrm{S}$ & 77 & 25 & $*$ & 102 \\
\hline Man & $\mathrm{M}$ & $\mathrm{S}$ & 89 & $*$ & $*$ & 89 \\
\hline Tei & $\mathrm{M}$ & $\mathrm{J}$ & 23 & $*$ & $*$ & 23 \\
\hline Jat & $\mathrm{M}$ & $\mathrm{J}$ & 52 & $*$ & $*$ & 52 \\
\hline Moc & $\mathrm{F}$ & $\mathrm{A}$ & 11 & 9 & 39 & 59 \\
\hline Dun & $\mathrm{F}$ & $\mathrm{J}$ & 2 & 1 & 15 & 18 \\
\hline Cat & $\mathrm{F}$ & $\mathrm{J}$ & 1 & 1 & 10 & 12 \\
\hline Erv & $\mathrm{F}$ & I & 0 & 0 & 5 & 5 \\
\hline Kic & $\mathrm{M}$ & I & 0 & 0 & 7 & 7 \\
\hline \multicolumn{3}{|c|}{ Total } & 339 & 76 & 197 & 612 \\
\hline
\end{tabular}


Durante o primeiro período, três indivíduos se destacaram pelo alto número de episódios de uso de ferramentas para quebra de cocos: Zangado, Dengoso e Mansinho. Já as fêmeas adultas Moça Branca e Emília e as juvenis Dunga e Catuaba mostraram pouco envolvimento com esta atividade. Estes resultados são semelhantes aos encontrados por Mannu (2002) e Resende (2004) onde os machos foram mais ativos que as fêmeas na quebra de cocos (embora no segundo estudo citado esta diferença não fosse significativa).

Mannu (op cit.) sugere que tal variação poderia indicar que existe grande variação individual entre os indivíduos nesta atividade e/ou que a habituação diferencial ao pesquisador pode influenciar na observação do comportamento. Este padrão se manteve constante nos meses subseqüentes, mesmo tendo a habituação de todos os indivíduos do grupo ao pesquisador aumentado notavelmente. Portanto, podemos afirmar que existe de fato uma grande variabilidade na freqüência da quebra de cocos entre os indivíduos do grupo estudado. Com a migração dos quatro machos subadultos para fora do grupo, Zangado passou a ser o macaco que mais se envolveu na quebra. As Tabelas 4 e 5 mostram os episódios de quebra distribuídos por faixa etária e sexo para cada período.

Tabela 4: Episódios de quebra (Quebra Inepta + Quebra Adequada + Quebra Proficiente + Quebra Não-Determinada) realizados pelos indivíduos do "Grupo de Zangado" durante o período de coleta, distribuídos por faixa etária. $(\mathrm{n})$ = número de indivíduos por categoria em cada período.

\begin{tabular}{|c|c|c|c|c|}
\cline { 2 - 5 } \multicolumn{1}{c|}{} & \multicolumn{4}{c|}{ Episódios de Quebra } \\
\hline Faixa etária & P1 & P2 & P3 & Total \\
\hline Adultos/Subadultos & $261(6)$ & $74(5)$ & $160(4)$ & 495 \\
\hline Juvenis & $78(4)$ & $2(2)$ & $25(2)$ & 105 \\
\hline Infantes & $0(2)$ & $0(2)$ & $12(2)$ & 12 \\
\hline
\end{tabular}

Tabela 5: Episódios de quebra (Quebra Inepta + Quebra Adequada + Quebra Proficiente + Quebra Não-Determinada) realizados pelos indivíduos do "Grupo de Zangado" durante o período de coleta, distribuídos por sexo. $(\mathrm{n})$ = número de indivíduos por categoria em cada período.

\begin{tabular}{|c|c|c|c|c|}
\cline { 2 - 5 } \multicolumn{1}{c|}{} & \multicolumn{4}{c|}{ Episódios de Quebra } \\
\hline Sexo & P1 & P2 & P3 & Total \\
\hline Machos & $322(6)$ & $58(3)$ & $114(2)$ & 494 \\
\hline Fêmeas & $17(6)$ & $18(6)$ & $83(6)$ & 118 \\
\hline
\end{tabular}


No primeiro período, vemos que os adultos são responsáveis por $77 \%$ dos episódios, seguidos dos juvenis com 23\%; no entanto, não houve diferença estatística significativa entre tais faixas etárias (Mann-Whitney, $U=8,00 ; Z=0,8528 ; p=0.3938$ ). Os infantes não exibiram o comportamento de quebra de cocos neste período. No segundo período, essa diferença se acentua, com os adultos (97\%) quebrando muito mais que os juvenis (3\%). No terceiro período, esse padrão se manteve, sendo os adultos (81\%), seguidos dos juvenis (13\%) - e somente agora os infantes participando discretamente da quebra, com 6\% dos episódios. Esta mudança está relacionada ao amadurecimento de Kico e Ervilha.

Os machos apresentam uma freqüência do comportamento em questão muito maior que das fêmeas, sendo responsáveis por $95 \%$ dos episódios registrados para o primeiro período (Mann-Whitney, $U=5,50 ; Z=2,0016 ; p=0,0453$ ). Importante notar que a fêmea Moça Chita foi responsável pela maioria dos episódios $(65 \%)$ de quebra da sua categoria nesse primeiro período. No segundo período essa diferença diminui e, devido ao baixo número de indivíduos, não houve diferença significativa (Mann-Whitney, $U=5,00 ; Z=$ $1,0328 ; \mathrm{p}=0,3017)$ entre as classes de sexo. Mas se observarmos os dados veremos que os machos $(\mathrm{N}=3)$ ainda são responsáveis, em termos absolutos, pela maioria dos episódios de quebra (76\%; fêmeas: $\mathrm{N}=6)$.

No terceiro período essa tendência diminui ainda mais, sendo os machos responsáveis por $58 \%$ dos eventos. Isso ocorreu porque os únicos machos no grupo eram, então, Zangado (adulto/dominante) e Kico (infante), sendo o primeiro responsável por 94\% dos episódios de quebra por machos.

Apesar da evidente diferença nas freqüências médias de episódios entre as categorias de faixas etárias, os desvios-padrão são muito altos, chegando a se equiparar ou até a serem maiores que as médias, o que evidencia a enorme variação individual quando juntamos os sujeitos nas categorias supracitadas. Os machos foram muito mais ativos na quebra do que fêmeas durante todo o período de coleta de dados. Os infantes, que não exibiram a atividade de quebra nos primeiros meses, se engajaram nesta atividade no terceiro período. $\mathrm{O}$ infante macho Kico foi observado utilizando pedras para quebra de cocos (pedaço do coco), pela primeira vez, com dez meses de idade e a fêmea Ervilha com um ano e seis meses, ambos os episódios foram classificados como Quebra Inepta. 
As médias e desvios-padrão para os episódios de quebra para os três períodos, distribuídos por faixa etária e sexo, estão indicados nas Figuras 2 e 3 (ver Anexos I e J respectivamente).

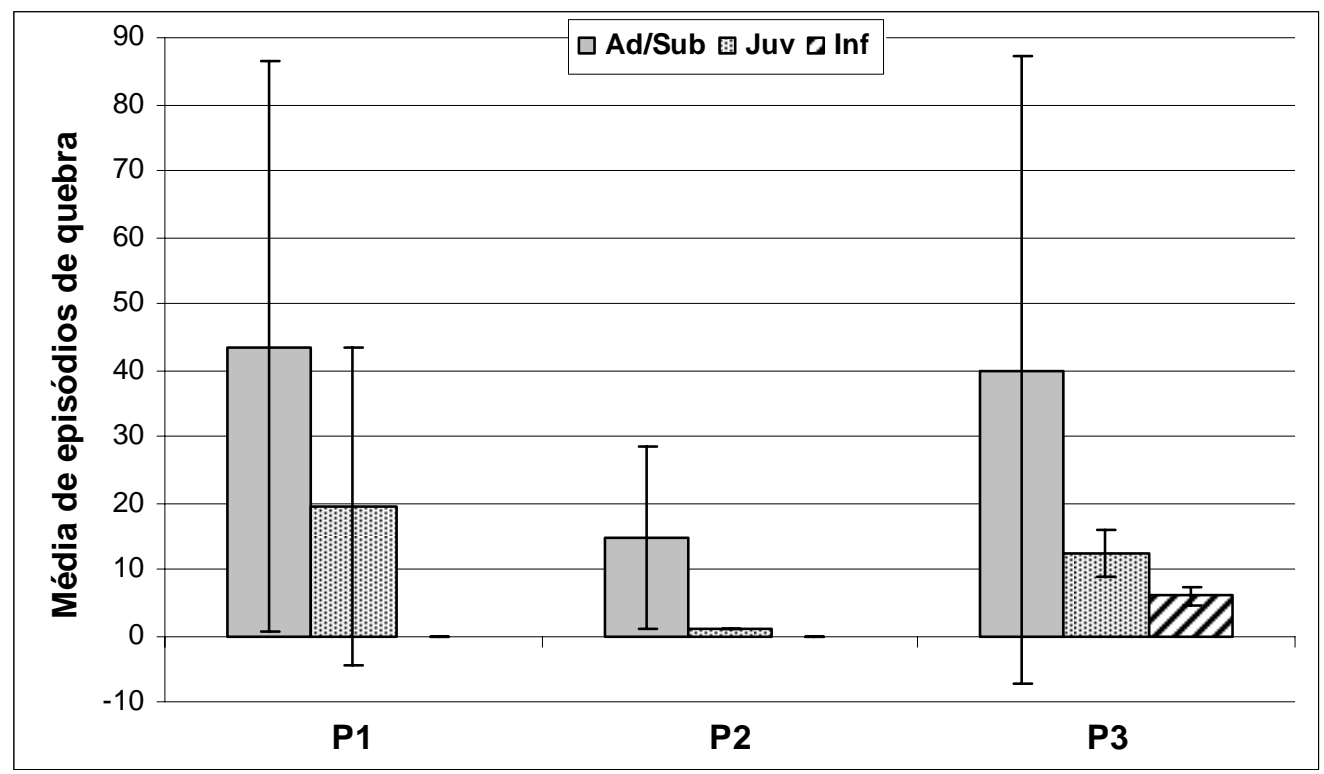

Figura 2: Média dos episódios de quebra de cocos e desvios-padrão para os três períodos de coleta de dados, distribuídos por faixas etárias. Ad/Sub: Adultos/Subadultos; Juv: Juvenis; Inf: Infantes; P1: Primeiro período; P2: Segundo período; P3: Terceiro período.

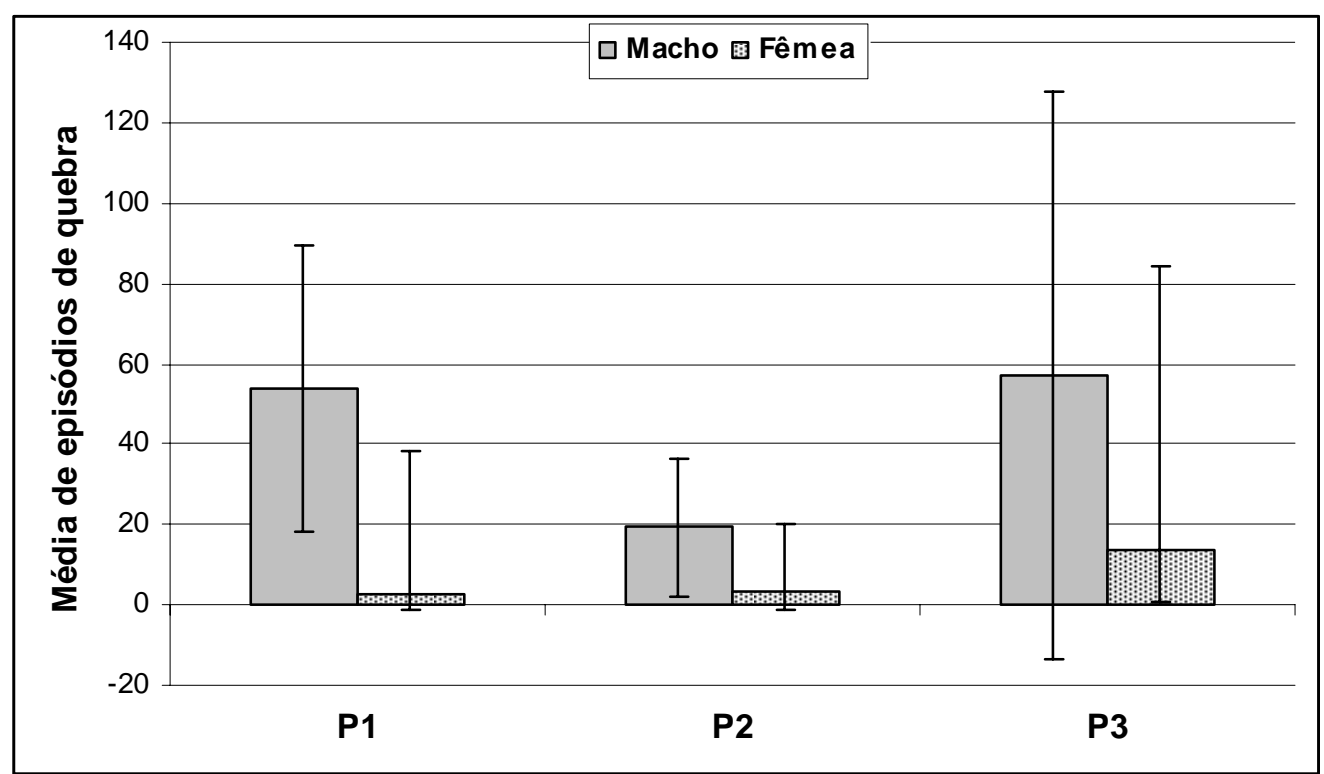

Figura 3: Média dos episódios de quebra de cocos e desvios-padrão, para os três períodos de coleta de dados, distribuídos por sexo. Machos e Fêmeas; P1: Primeiro período; P2: Segundo período; P3: Terceiro período. 


\subsubsection{Proficiência do Quebrador}

Para as análises a seguir, utilizamos apenas os episódios em que foi possível quantificar o número de cocos quebrados pelos sujeitos $(\mathrm{N}$ de episódios: $\mathrm{P} 1=305 ; \mathrm{P} 2=52$; P3 $=186)$. Houve grandes diferenças individuais quanto à proficiência na quebra de cocos. Calculamos, para cada indivíduo e para cada classe de sexo e faixa etária, a Taxa de Proficiência na quebra de cocos (Figura 4; Anexo N), obtida através da divisão do total de episódios proficientes $(\mathrm{QP})$, pela freqüência absoluta de episódios de quebra $(\mathrm{QP}+\mathrm{QA}+\mathrm{QI})$. Cabe ressaltar que os cocos quebrados pelos indivíduos em nosso local de estudo são maiores e mais duros que os cocos manipulados pelos macacos do Parque Ecológico do Tietê (Mannu, 2002; Ottoni , et al. 2005; Coelho, dados não publicados), onde foram realizados os estudos com cujos resultados pretendemos comparar os nossos.

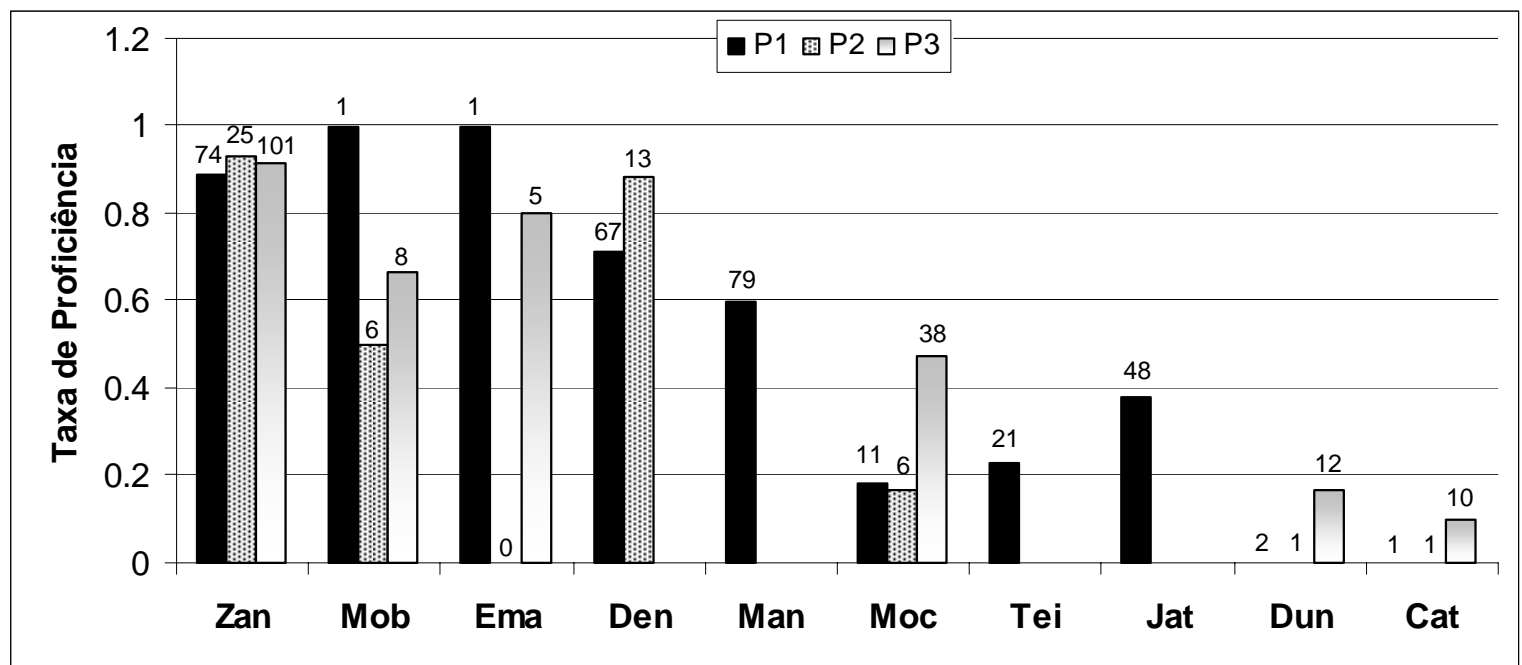

Figura 4: Taxa de proficiência individual e número de episódios de quebra nos três períodos da coleta de dados pelos métodos de Todas as Ocorrências e Evento Focal; Total de episódios proficientes dividido pelo Total de episódios.

Durante o primeiro período os adultos/subadultos exibiram altas Taxas de Proficiência na quebra, com exceção da fêmea Moça Chita. Cabe notar que neste período, as fêmeas Moça Branca e Emilia apresentaram apenas um episódio de quebra cada - mas como foram proficientes nestes eventos, ambas apresentam a maior Taxa de Proficiência; este resultado modificou-se quando analisamos os episódios de quebra dos outros períodos de coleta de dados (10 meses seguintes). 
Durante todo o período de coleta o macho dominante (Zangado) apresentou as maiores Taxas de Proficiência do grupo. Os juvenis machos, Teimoso e Jatobá, conseguiram quebrar cocos em 5 e 18 episódios, respectivamente, enquanto as fêmeas juvenis, Dunga e Catuaba, que não obtiveram sucesso em nenhum episódio de quebra no primeiro e segundo períodos, melhoraram seu desempenho nos meses seguintes. Os infantes (Ervilha e Kico) só utilizaram ferramentas a partir do segundo período, mas não foram proficientes em nenhum episódio. As Figuras 5 e 6 mostram as Taxas de Proficiência distribuídas por sexo e faixa etária, respectivamente.

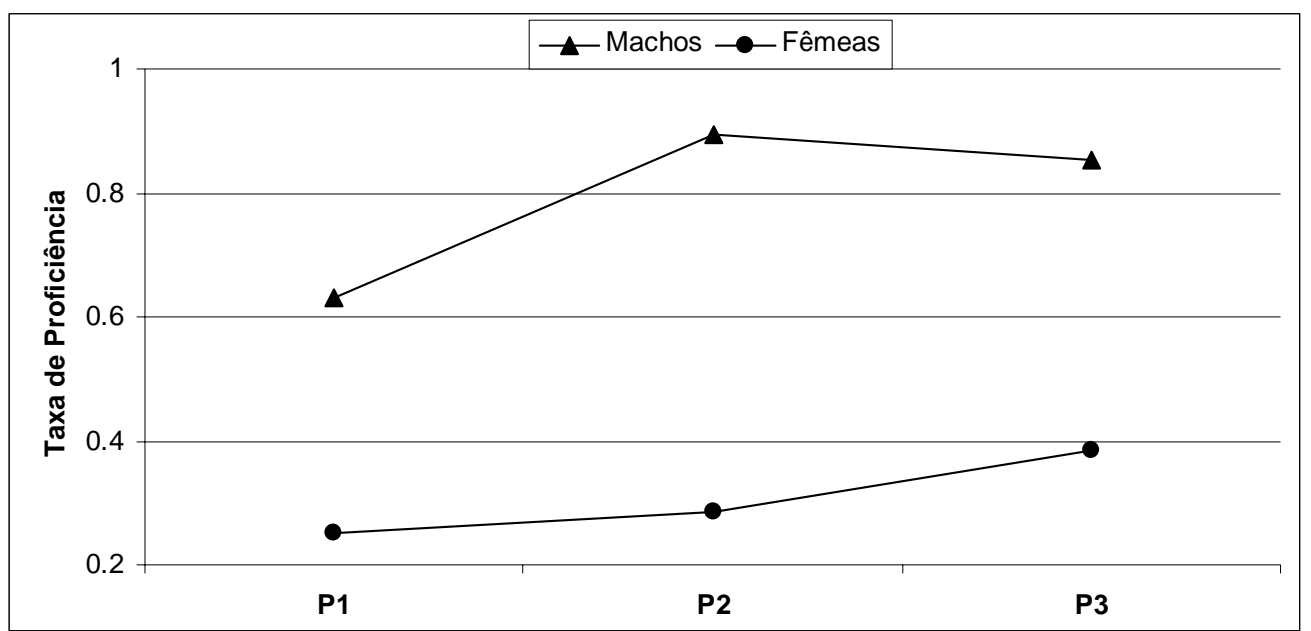

Figura 5: Taxa de Proficiência para os três períodos de coleta de dados, distribuídos por sexo. Total de episódios proficientes dividido pelo total de episódios. P1: Primeiro período; P2: Segundo período; P3: Terceiro período.

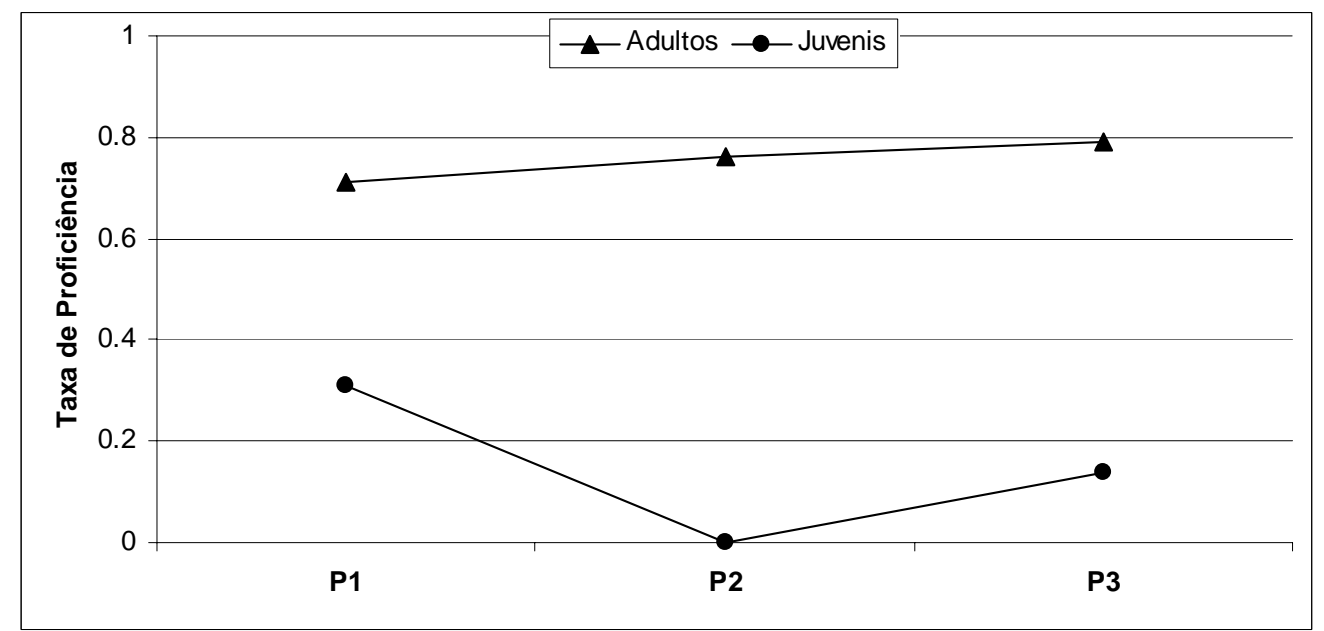

Figura 6: Taxa de Proficiência para os três períodos de coleta de dados, distribuídos por faixa etária. Total de episódios proficientes dividido pelo total de episódios. P1: Primeiro período; P2: Segundo período; P3: Terceiro período. 
Quando comparamos as faixas etárias quanto à Taxa de Proficiência, obtivemos uma diferença significativa: os adultos foram mais proficientes do que os juvenis no primeiro período de coleta (Mann-Whitney, $U=2,00 ; Z=2,1320 ; p=0,0330$ ). No segundo período os juvenis não foram proficientes em nenhum episódio, mas voltaram a quebrar cocos no terceiro período. Em todos os períodos, como indicado acima, os infantes não foram capazes de quebrar cocos para ter acesso ao endosperma.

Note-se que os machos são mais proficientes que as fêmeas durante todo o período de coleta de dados. No entanto, devido ao baixo número de indivíduos, o que prejudica a análise estatística, não houve diferença significativa entre as classes de sexo para o primeiro e segundo período (Mann-Whitney, P1: $U=14,50 ; Z=0,5604 ; p=0,5752$ / P2: $U=4,00 ; Z=$ $1,2910 ; \mathrm{p}=0,1967)$.

As Taxas de Produtividade estão apresentadas na Figura 7 (Anexo O) e foram calculadas dividindo-se a quantidade total de cocos quebrados por cada indivíduo pela freqüência absoluta de episódios de quebra de cada sujeito. A Taxa de Produtividade para o Grupo de Zangado foi de 0,75 e 0,84 cocos/episódio para o primeiro e segundo períodos, respectivamente.

Novamente, as fêmeas Moça Branca e Emília apresentam altas taxas nos episódios de quebra, superadas apenas por Zangado (macho dominante) - com a maior Taxa de Produtividade do grupo. Moça Chita, Dunga e Catuaba demonstraram um aumento na Taxa de Produtividade, já que obtiveram maior sucesso na quebra no terceiro período.

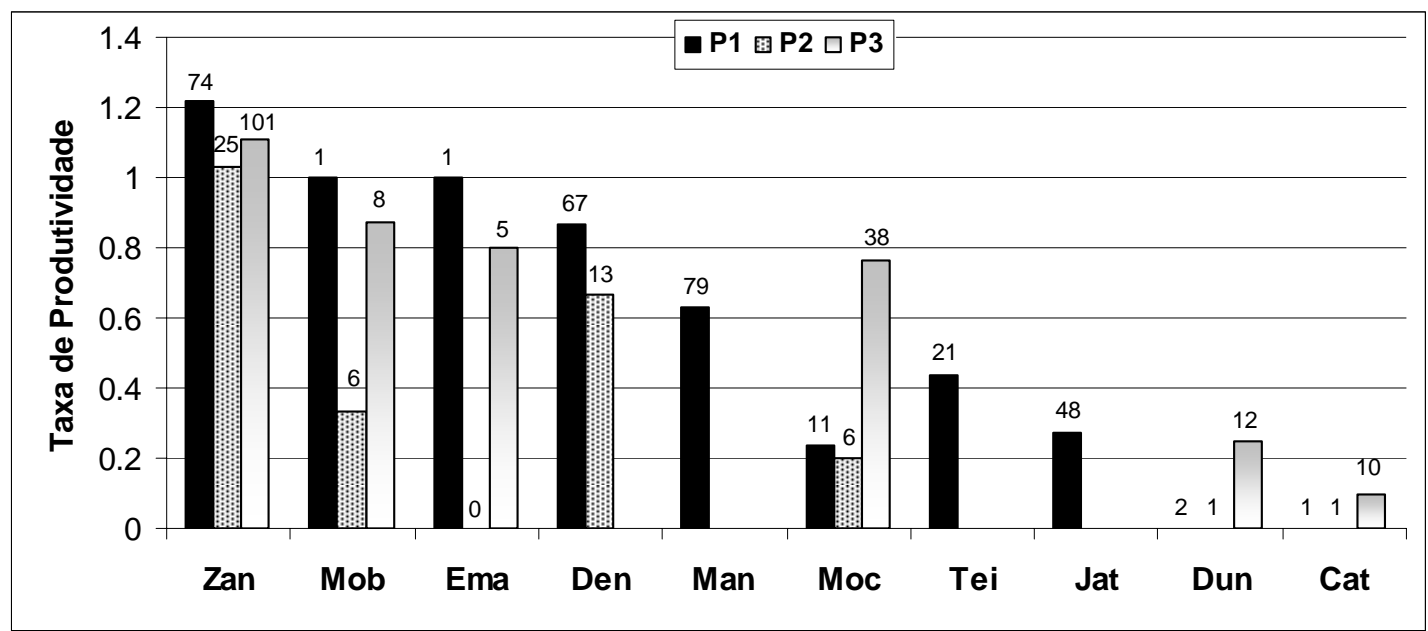

Figura 7: Taxa de produtividade individual e número de episódios de quebra nos dois períodos da coleta de dados pelos métodos de Todas as Ocorrências e Evento Focal; Total de cocos quebrados/Total de episódios de quebra. 


\subsubsection{Observação da Quebra de Cocos por Coespecíficos}

A observação por coespecíficos ocorreu em 138 dos 543 episódios de quebra de cocos considerados para esta análise (25\%). Em 22 destes episódios houve dois observadores, em 5 episódios, três observadores e em 2 episódios, quatro observadores, portanto o número de eventos observacionais foi de 180 .

Zangado (macho dominante) teve 90 dos seus 200 episódios de quebra observados por coespecíficos (45\%), tendo sido o indivíduo mais observado do grupo durante todo o período de coleta de dados. Este resultado está de acordo com dados anteriores, de grupos em semiliberdade, sobre a atração de macacos-prego imaturos pelo comportamento do macho dominante na quebra de cocos (Resende, 2004; Silva \& Ottoni, 2005). Além disso, Sestini \& Ottoni (1999) já haviam verificado que a atividade dos adultos que mais atrai a atenção dos indivíduos mais jovens é a manipulação de alimentos. As Taxas de Observação foram obtidas através do número de episódios observacionais que o indivíduo foi alvo dividido pelo número total de eventos de quebra de cocos por sujeito (Figura 8).

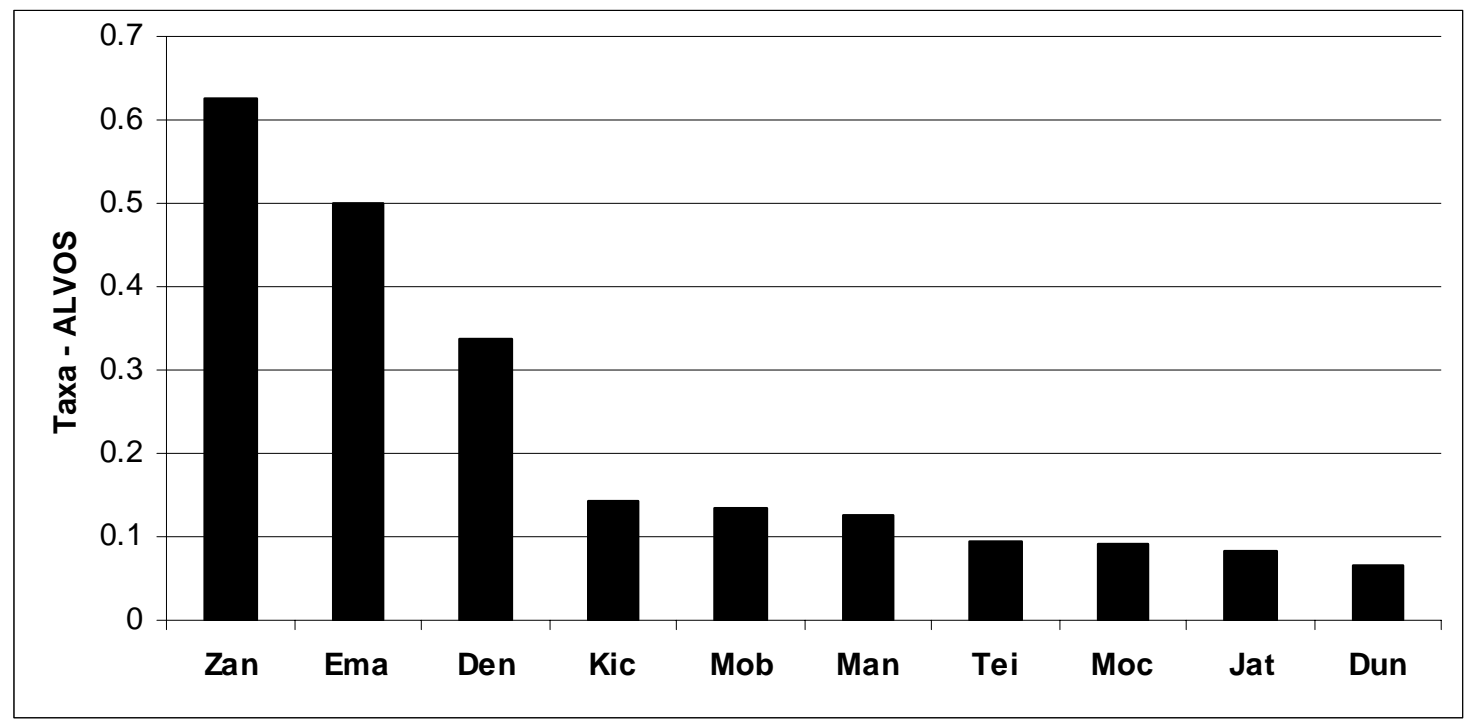

Figura 8: Taxas de Observação individual dirigidas a cada sujeito-alvo durante todo o período de coleta de dados (número de episódios observacionais em que o indivíduo foi alvo dividido pelo número total de eventos de quebra de cocos por sujeito).

No primeiro período, o juvenil Jatobá foi o indivíduo que mais se engajou na atividade de observação, sendo responsável por $30 \%$ dos eventos observacionais, e também foi o macaco que mais quebrou cocos em sua faixa etária. Moça Chita se destaca por observar 59\% 
dos eventos observacionais por fêmeas durante todo o período, e, como já vimos, também é a fêmea que mais usou ferramentas para a quebra de cocos.

As Tabelas 6 e 7 agrupam os sujeitos nas categorias de sexo e faixa etária, respectivamente. No primeiro período, desconsiderando o único episódio de quebra de Emília, que foi observado por Jatobá, todos os alvos foram machos, portanto significativamente mais observados que as fêmeas (Mann-Whitney, P1: $U=3,50 ; Z=2,3219 ; p=0,0202$ ). Isto se deve, inclusive, ao baixo número de episódios de quebra amostrados para fêmeas (quando comparado aos machos), neste período, havendo pouca oportunidade para elas fossem alvos potenciais. Nos períodos seguintes essa tendência se manteve, no total os machos foram alvos em 93\% dos eventos observacionais. No entanto, devido à grande variação entre os indivíduos, no que se refere a serem alvos de observação, não encontramos diferença significativa entre os sexos no período subseqüente de coleta (Mann-Whitney, $\mathrm{P} 2$ : $\mathrm{U}=4 ; \mathrm{Z}=$ $1,291 ; \mathrm{p}=0,1967)$.

Responsáveis pela grande maioria dos episódios de quebra, adultos/subadultos foram alvos de observação em 95\% do total de eventos observados. Os Anexos A, B e C - mostram as díades observador/alvo.

Tabela 6: Episódios de observação da quebra de cocos por coespecíficos, nos três períodos de coleta pelos métodos Evento Focal e Todas as Ocorrências, distribuídos por categorias de sexo.

\begin{tabular}{|c|c|c|c|c|c|c|c|c|c|c|c|c|}
\hline \multirow{2}{*}{$\begin{array}{r}\text { Alvo } \\
\text { Observador }\end{array}$} & \multicolumn{4}{|c|}{ Macho } & \multicolumn{4}{|c|}{ Fêmea } & \multicolumn{4}{|c|}{ Total } \\
\hline & $\mathrm{P} 1$ & $\mathrm{P} 2$ & P3 & TT & P1 & $\mathrm{P} 2$ & P3 & TT & $\mathrm{P} 1$ & $\mathrm{P} 2$ & P3 & TT \\
\hline Macho & 49 & 13 & 28 & 90 & 1 & 1 & 3 & 5 & 50 & 14 & 31 & 95 \\
\hline Fêmea & 30 & 16 & 32 & 68 & 0 & 1 & 0 & 7 & 30 & 17 & 38 & 85 \\
\hline Total & 79 & 29 & 60 & 168 & 1 & 2 & 9 & 12 & 80 & 31 & 69 & 180 \\
\hline
\end{tabular}

Tabela 7: Episódios de observação da quebra de cocos por coespecíficos, nos três períodos de coleta pelos métodos Evento Focal e Todas as Ocorrências, distribuídos por faixa etária.

\begin{tabular}{|c|c|c|c|c|c|c|c|c|c|c|c|c|c|c|c|c|}
\hline \multirow{2}{*}{$\begin{array}{r}\text { Alvo } \\
\text { Observador }\end{array}$} & \multicolumn{4}{|c|}{ Adultos/Subadultos } & \multicolumn{4}{|c|}{ Juvenis } & \multicolumn{4}{|c|}{ Infantes } & \multicolumn{4}{|c|}{ Total } \\
\hline & $\mathrm{P} 1$ & $\mathrm{P} 2$ & $\mathrm{P} 3$ & TT & $\mathrm{P} 1$ & $\mathrm{P} 2$ & $\mathrm{P} 3$ & TT & $\mathrm{P} 1$ & $\mathrm{P} 2$ & $\mathrm{P} 3$ & TT & $\mathrm{P} 1$ & $\mathrm{P} 2$ & $\mathrm{P} 3$ & TT \\
\hline Adultos/Subadultos & 31 & 18 & 22 & 71 & 3 & 0 & 0 & 3 & 0 & 0 & 1 & 1 & 34 & 18 & 23 & 75 \\
\hline Juvenis & 33 & 1 & 9 & 43 & 0 & 0 & 0 & 0 & 0 & 0 & 0 & 0 & 33 & 1 & 9 & 43 \\
\hline Infantes & 10 & 12 & 36 & 58 & 3 & 0 & 1 & 4 & 0 & 0 & 0 & 0 & 13 & 12 & 37 & 62 \\
\hline Total & 74 & 31 & 67 & 172 & 6 & 0 & 1 & 7 & 0 & 0 & 1 & 1 & 80 & 31 & 69 & 180 \\
\hline
\end{tabular}


Analisando o primeiro período de coleta de dados observamos que, adultos/subadultos e Juvenis foram alvos de observação em freqüências esperadas pelo acaso (Mann-Whitney $\mathrm{P} 1: \mathrm{U}=8 ; \mathrm{Z}=0,8528 ; \mathrm{p}=0,3938$ ). Para os períodos seguintes, devido ao baixo número de indivíduos nas categorias etárias, não foi possível realizar análises estatísticas. No entanto, os adultos/subadultos foram os mais observados (Figura 9). Não incluímos os infantes nesta análise já que houve apenas um episódio de observação em que um indivíduo desta faixa etária (Kico) foi alvo.

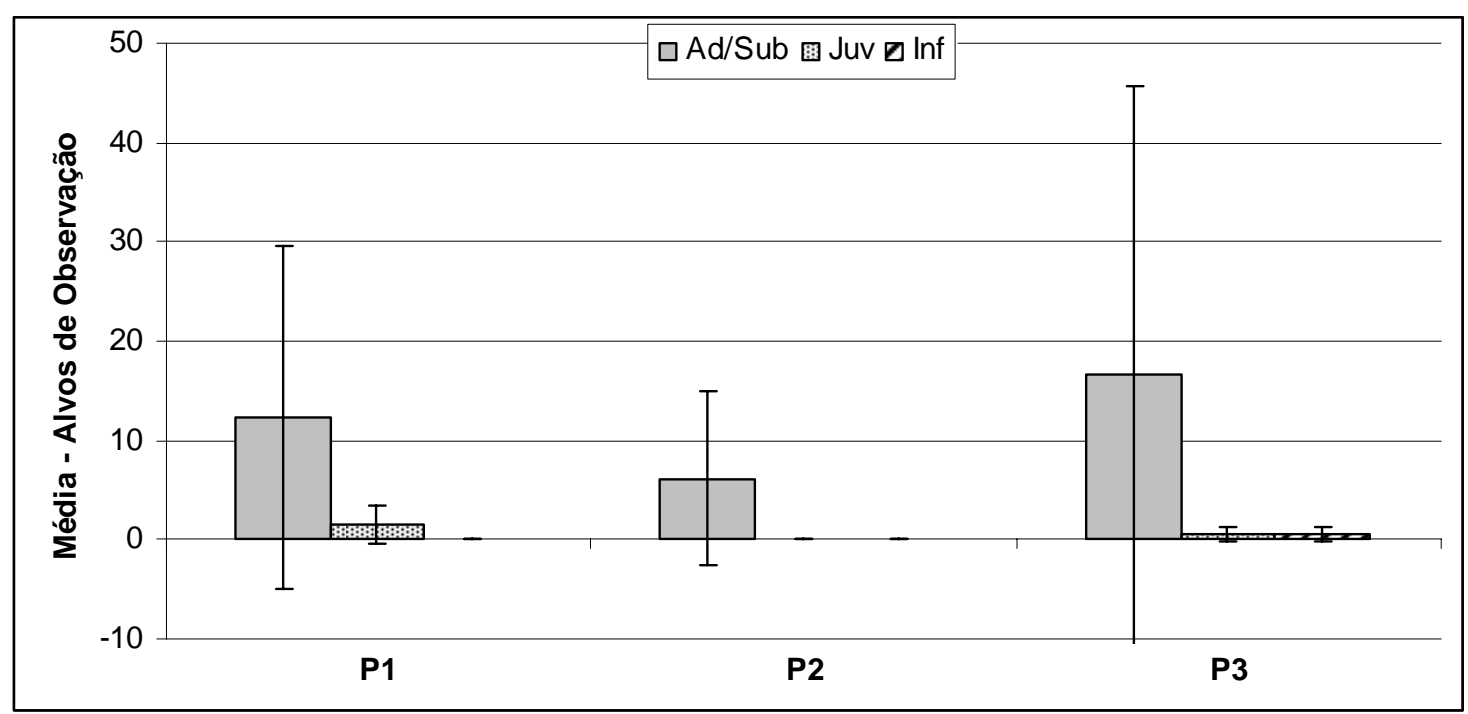

Figura 9: Média dos episódios de observação (e desvios-padrão) dos indivíduos enquanto alvos para os três períodos de coleta, distribuídos por faixa etária. $\mathrm{Ad} / \mathrm{Sub}$ : Adultos/Subadultos; Juv: Juvenis; Inf: Infantes; P1: Primeiro período; P2: Segundo período; P3: Terceiro período.

Se agruparmos os dados de todos os períodos $(\mathrm{P} 1+\mathrm{P} 2+\mathrm{P} 3)$ de coleta, vemos que os adultos/subadultos foram mais observados que os juvenis (Mann-Whitney, $U=2,50 ; \mathrm{Z}=$ 2,0254; $\mathrm{p}=0,0428$ ), e que dentre os adultos/subadultos, os machos foram significativamente mais observados que as fêmeas (Mann-Whitney, $U=0 ; Z=1,964 ; p=0,0495$ ) (Figura 10). 


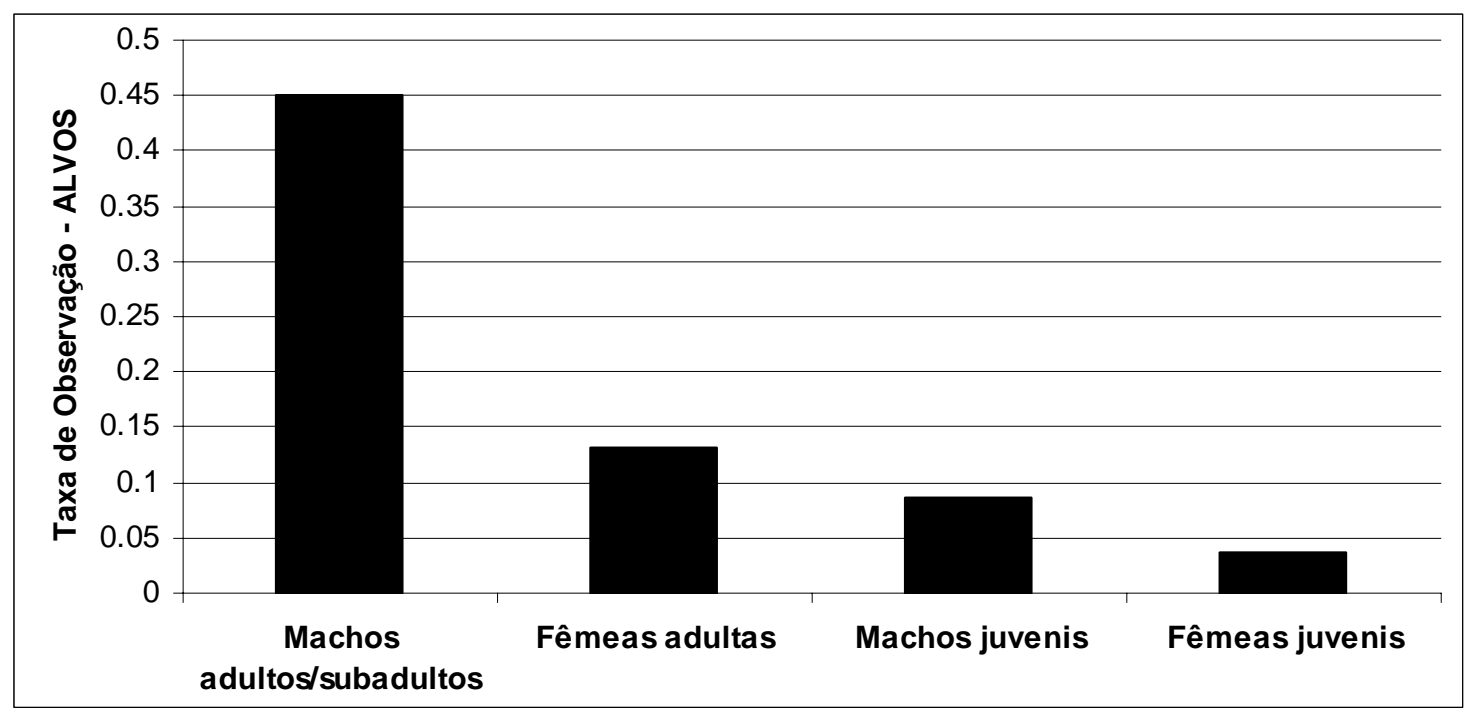

Figura 10: Taxas de observação dos indivíduos de cada classe de sexo-faixa etária enquanto alvos para os três períodos de coleta; Total de eventos observacionais (como alvos), dividido pelo Total de episódios de quebra de cada categoria de faixa etária-sexo.

Para uma melhor comparação entre as faixas sexo/idade quanto ao comportamento de observar a quebra de cocos, calculamos as médias de episódios de observação (Figura 11 e 12). No entanto, os desvios-padrão são muitos altos (ver Anexos L e M) o que evidencia a grande variação individual.

No primeiro período de coleta, o comportamento de observar a quebra de cocos por outros indivíduos foi semelhante para todas as faixas etárias, adultos/subadultos e juvenis não se mostraram significativamente diferentes (Mann-Whitney, $U=8 ; Z=0,8528 ; p=0,3938$ ). No segundo período, os infantes foram os mais observadores, e no terceiro período, foram responsáveis por $54 \%$ dos episódios de observação. Isto deve ter ocorrido devido ao desenvolvimento destes filhotes (Kico e Ervilha) que, ao adquirirem gradativa independência da mãe, vão demonstrando maior interesse e oportunidade de observar as atividades dos outros indivíduos do grupo, especialmente o macho dominante (Zangado).

Quando comparamos machos e fêmeas, foi comprovada a hipótese nula de que ambos os sexos observaram a quebra de cocos em freqüências esperadas pelo acaso (Mann-Whitney, $\mathrm{P} 1: \mathrm{U}=11 ; \mathrm{Z}=1,1209 ; \mathrm{p}=0,2623 / \mathrm{P} 2: \mathrm{U}=7 ; \mathrm{Z}=0,5164 ; \mathrm{p}=0,6056)$. No terceiro período, contando com apenas dois machos, Kico foi responsável por todos os episódios de observação da sua categoria de sexo (Zangado não apresentou tal comportamento) apresentando o dobro de eventos observacionais registrados individualmente por fêmeas. 


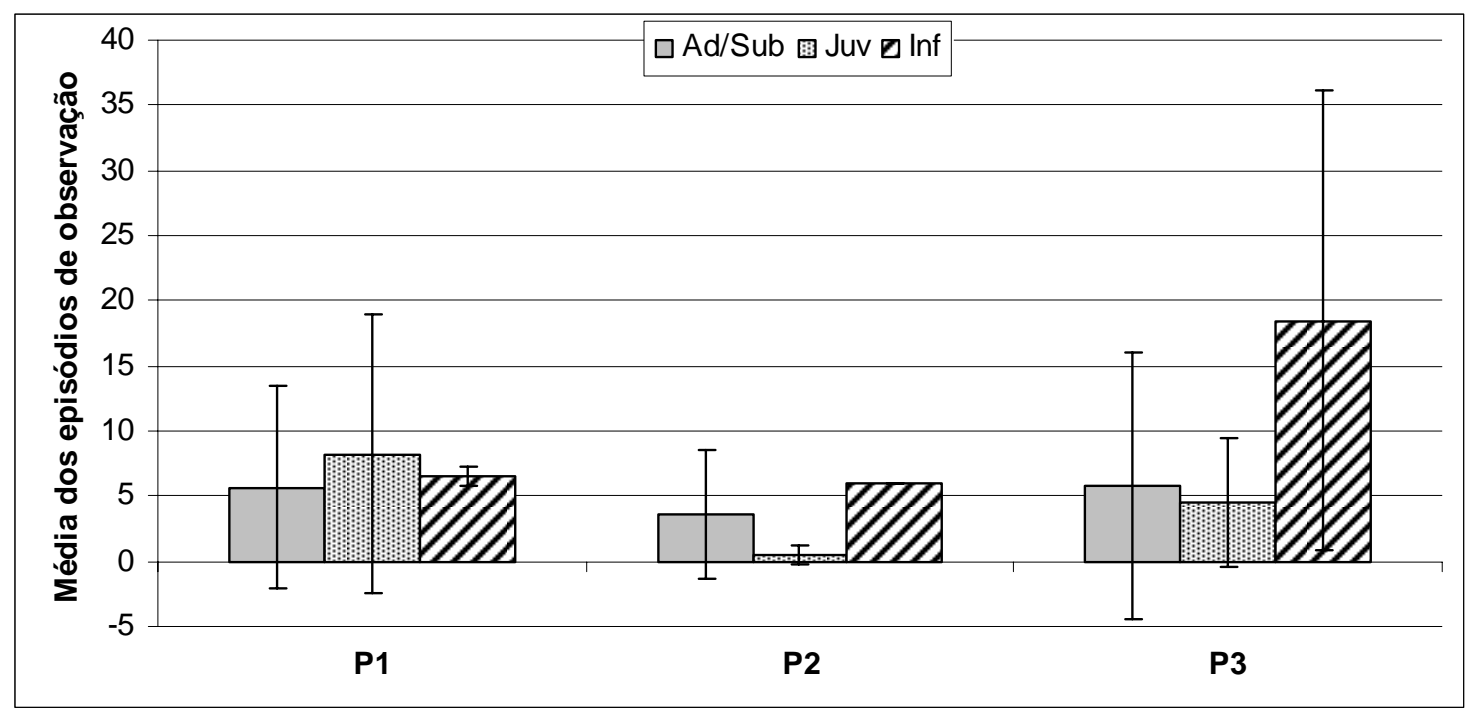

Figura 11: Média de Eventos Observacionais e desvios-padrão para os três períodos de coleta, distribuídos por faixa etária. Ad/Sub: Adultos/Subadultos; Juv: Juvenis; Inf: Infantes; P1: Primeiro período; P2: Segundo período; P3: Terceiro período.

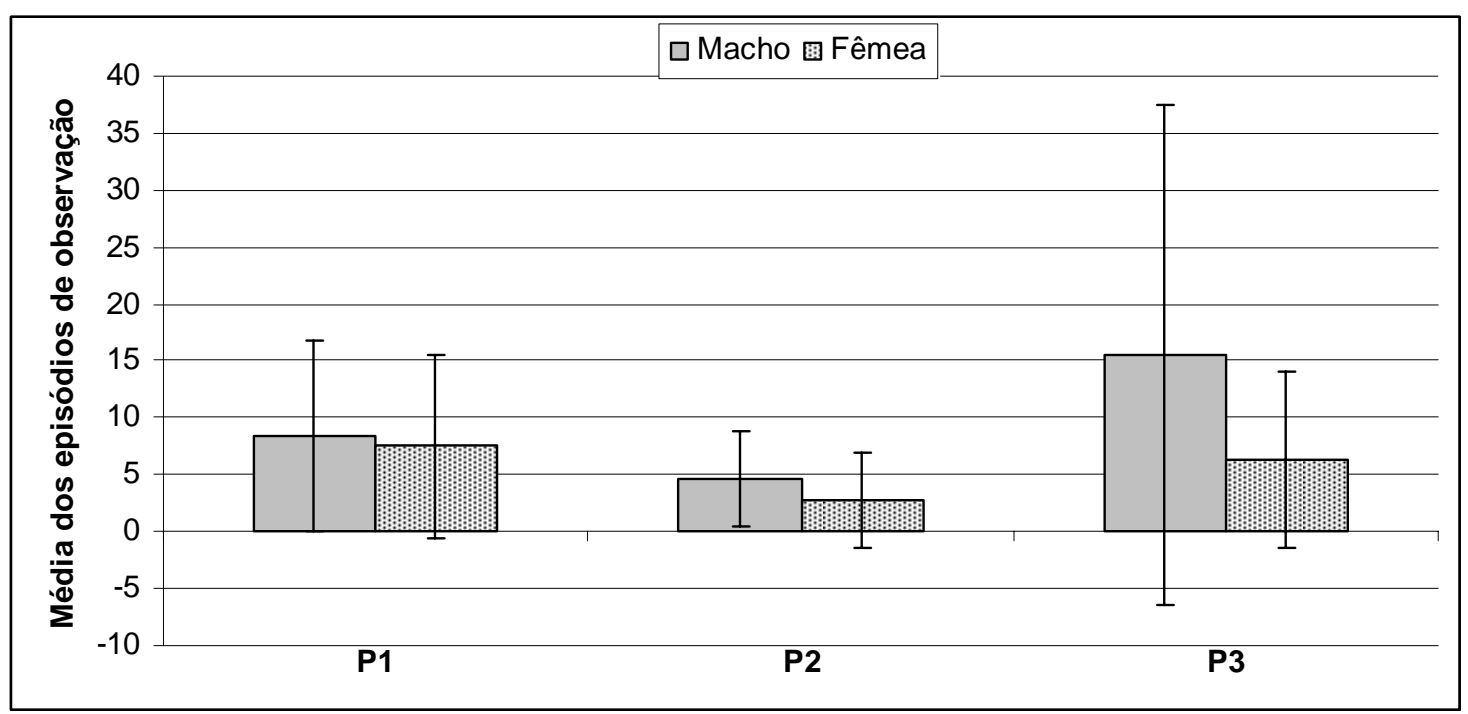

Figura 12: Média de Eventos Observacionais e desvios-padrão para os três períodos de coleta, distribuídos por sexo. Machos e Fêmeas; P1: Primeiro período; P2: Segundo período; P3: Terceiro período. 


\subsubsection{Comportamentos Manipulativos do Observador}

Pela análise dos dados coletados pelo método do Evento Focal, podemos verificar que $35 \%(\mathrm{~N}=45)$ dos eventos de observação da quebra de $\operatorname{cocos}(\mathrm{N}=127)$ foram seguidos de Comportamento Manipulativo, por parte do observador, dos itens do sítio de quebra. Em 8 episódios a manipulação ocorreu na presença do alvo, em 33 episódios em sua ausência e em 4 episódios a manipulação ocorreu tanto na presença quanto na ausência do alvo. A Tabela 8 , lista o número de episódios para cada comportamento manipulativo do observador (em quatro destes eventos não foi possível identificar a manipulação realizada pelo observador, portanto excluímos esses eventos da Tabela).

Kico foi o indivíduo que mais se engajou na manipulação dos itens do sítio logo após ter observado o alvo $(\mathrm{N}=15)$, seguido por Moça-Chita $(\mathrm{N}=8)$.

Tabela 8: Comportamentos Manipulativos do observador após os eventos de observação de quebra de cocos. As colunas indicam a categoria do episódio de quebra exibido pelo alvo de observação. QI: Quebra Inepta; QA: Quebra Adequada; Quebra Proficiente. Dados coletados pelo método do Evento Focal.

\begin{tabular}{|c|c|c|c|c|}
\hline \multirow{2}{*}{ Comportamento Manipulativo } & \multicolumn{5}{|c|}{ Número de Episódios } \\
\cline { 2 - 5 } & QI & QA & QP & Total \\
\hline Manipulação de coco & 0 & 0 & 7 & 7 \\
\hline Manipulação de pedra & 0 & 2 & 2 & 4 \\
\hline Quebra Inepta & 0 & 1 & 5 & 6 \\
\hline Quebra Adequada & 0 & 1 & 12 & 13 \\
\hline Quebra Proficiente & 1 & 1 & 9 & 11 \\
\hline Total & 1 & 5 & 35 & 41 \\
\hline
\end{tabular}

Em um destes episódios, o infante macho Kico, observando a quebra de cocos pelo Zangado, agarrou um pedaço de coco sobre o sítio de quebra e posicionou-se de frente ao macho dominante e, ao mesmo tempo em que Zangado quebrava seu coco, realizou movimentos empáticos de quebra com o pedaço de coco em uma de suas mãos, levantando e abaixando seu corpo como no movimento realizado por Zangado. 


\subsubsection{Scrounging e a Quebra de Cocos}

Para as análises relativas ao Scrounging utilizamos apenas os dados coletados pelo método do Evento Focal. Dos 297 episódios de quebra de cocos considerados, houve Scrounging por coespecíficos em 84 deles (28\%). Os episódios de Scrounging, distribuídos por faixa etária e sexo, estão indicados nas Tabelas 9 e 10. Consideramos apenas os episódios em que o receptor efetivamente ingere o item alimentar tornado acessível em conseqüência da manipulação pelo doador, excluindo as tentativas não-efetivas (episódios sem ingestão dos restos, não havendo, portanto, doador/receptor).

Em dezessete destes episódios houve dois Scroungers (por episódio), em oito episódios, três scroungers e em um episódio, quatro Scroungers. Além disso, o mesmo indivíduo pode, num mesmo evento de quebra, comer os restos deixados pelo alvo na presença deste (Scrounging Imediato) e também após este sair do sítio (Scrounging Mediato), sendo estas ocorrências contadas em separado. Por isso, o número de eventos de Scrounging ( $\mathrm{N}=154)$ é superior ao número de episódios em que houve Scrounging (As díades de doador/receptor estão nos Anexos D, E e F). Registramos 66 eventos de Scrounging Imediato (43\%) e 88 eventos de Scrounging Mediato (57\%).

Tabela 9: Episódios de Scrounging da quebra de cocos por coespecíficos, nos três períodos de coleta de dados pelo método Evento Focal, distribuídos pelas categorias de sexo.

\begin{tabular}{|c|c|c|c|c|c|c|c|c|c|c|c|c|}
\hline \multirow{2}{*}{$\begin{array}{l}\text { Doador } \\
\text { Receptor }\end{array}$} & \multicolumn{4}{|c|}{ Macho } & \multicolumn{4}{|c|}{ Fêmea } & \multicolumn{4}{|c|}{ Total } \\
\hline & P1 & $\mathrm{P} 2$ & P3 & TT & P1 & $\mathrm{P} 2$ & P3 & TT & P1 & $\mathrm{P} 2$ & P3 & TT \\
\hline Macho & 24 & 11 & 27 & 62 & 0 & 0 & 2 & 2 & 24 & 11 & 29 & 64 \\
\hline Fêmea & 30 & 22 & 36 & 88 & 0 & 0 & 2 & 2 & 30 & 22 & 38 & 90 \\
\hline Total & 54 & 33 & 63 & 150 & 0 & 0 & 4 & 4 & 54 & 33 & 67 & 154 \\
\hline
\end{tabular}

Tabela 10: Episódios de Scrounging da quebra de cocos por coespecíficos, nos três períodos de coleta de dados pelo método Evento Focal, distribuídos por faixa etária.

\begin{tabular}{|c|c|c|c|c|c|c|c|c|c|c|c|c|c|c|c|c|}
\hline \multirow{2}{*}{$\begin{array}{c}\text { Doador } \\
\text { Receptor }\end{array}$} & \multicolumn{3}{|c|}{ Adultos/Subadultos } & \multicolumn{4}{|c|}{ Juvenis } & \multicolumn{5}{c|}{ Infantes } & \multicolumn{5}{c|}{ Total } \\
\cline { 2 - 9 } & P1 & P2 & P3 & TT & P1 & P2 & P3 & TT & P1 & P2 & P3 & TT & P1 & P2 & P3 & TT \\
\hline Adultos/Subadultos & 29 & 15 & 24 & 68 & 0 & 0 & 0 & 0 & 0 & 0 & 0 & 0 & 29 & 15 & 24 & 68 \\
\hline Juvenis & 15 & 0 & 7 & 22 & 0 & 0 & 0 & 0 & 0 & 0 & 0 & 0 & 15 & 0 & 7 & 22 \\
\hline Infantes & 10 & 18 & 36 & 64 & 0 & 0 & 0 & 0 & 0 & 0 & 0 & 0 & 10 & 18 & 36 & 64 \\
\hline Total & 54 & 33 & 67 & 154 & 0 & 0 & 0 & 0 & 0 & 0 & 0 & 0 & 54 & 33 & 67 & 154 \\
\hline
\end{tabular}


No primeiro e no segundo períodos, as fêmeas foram responsáveis por pouquíssimos episódios de quebra, criando assim poucas oportunidades para que outros indivíduos as observassem ou realizassem Scrounging. Efetivamente, nos três primeiros meses (P1 e P2), apenas nos episódios de quebra dos machos houve Scrounging por coespecíficos. No período seguinte houve um pequeno aumento na média de episódios de quebra de cocos pelas fêmeas (ver acima) e estas foram, então, doadoras em quatro episódios (Ema, $\mathrm{N}=1$ e Moc, $\mathrm{N}=3$ ).

Quanto aos doadores, conforme o padrão visto nos eventos observacionais, Zangado foi o indivíduo que mais sofreu Scrounging, representando $61,5 \%$ do total de episódios, seguido de Dengoso (25\%), Mansinho (11,5\%) e Teimoso (2\%) no primeiro período. No período subseqüente, Zangado foi doador em $76 \%$ dos episódios de Scrounging seguido por Dengoso (24\%). No terceiro período, Zangado foi doador em $94 \%$ dos episódios, do total de episódios de Scrounging no grupo, Emília foi doadora em 1,5\% e Moça-Chita em 4,5\%.

Para uma melhor comparação entre os doadores, calculamos uma "Taxa do Doador" dividindo o número de episódios em que cada indivíduo foi doador pelo número total de episódios de quebra de cocos por sujeito (Figura 13).

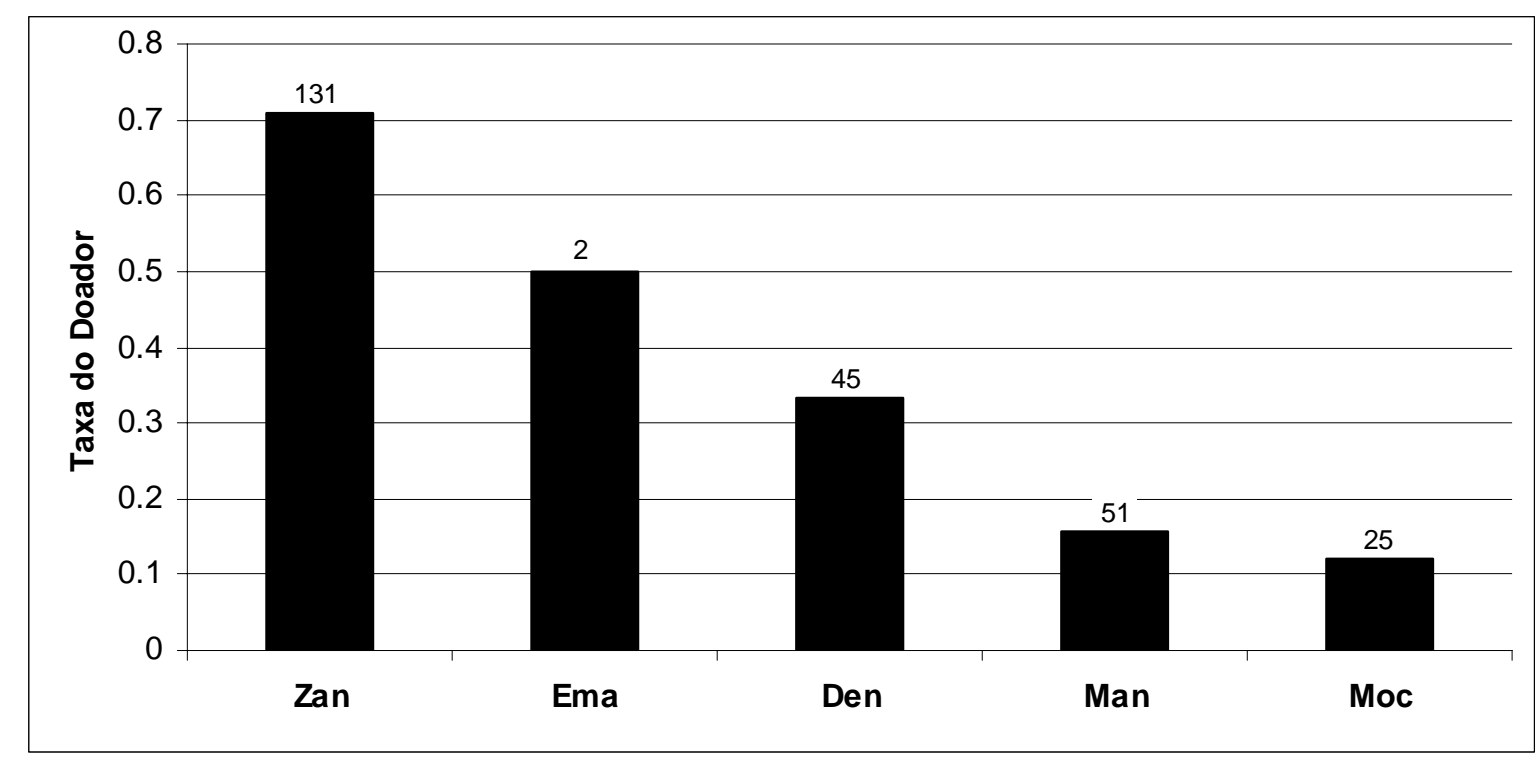

Figura 13: "Taxa do Doador" e número de episódios de quebra, para todo o período de coleta de dados pelo método do Evento Focal, distribuídos por sujeito (número de episódios em que cada indivíduo foi doador dividido pelo número total de episódios de quebra de cocos por sujeito). 
No primeiro período, Moça Chita foi responsável por $34 \%(\mathrm{~N}=28)$ dos episódios de Scrounging, seguida por Jatobá com 23\% $(\mathrm{N}=19)$. No terceiro período, Kico e Moça Chita se destacam sendo receptores em $43 \%(\mathrm{~N}=29)$ e $30 \%(\mathrm{~N}=20)$, respectivamente, dos episódios deste período.

\subsubsection{Scrounging e Observação na Quebra de Cocos}

Aqui, como no item anterior, utilizamos nesta análise somente os dados coletados pelo método do Evento Focal. Na Figura 14, devido ao interesse na relação entre observação e Scrounging, destacamos, para cada indivíduo observador, os episódios de observação da quebra que resultaram em episódios de Scrounging.

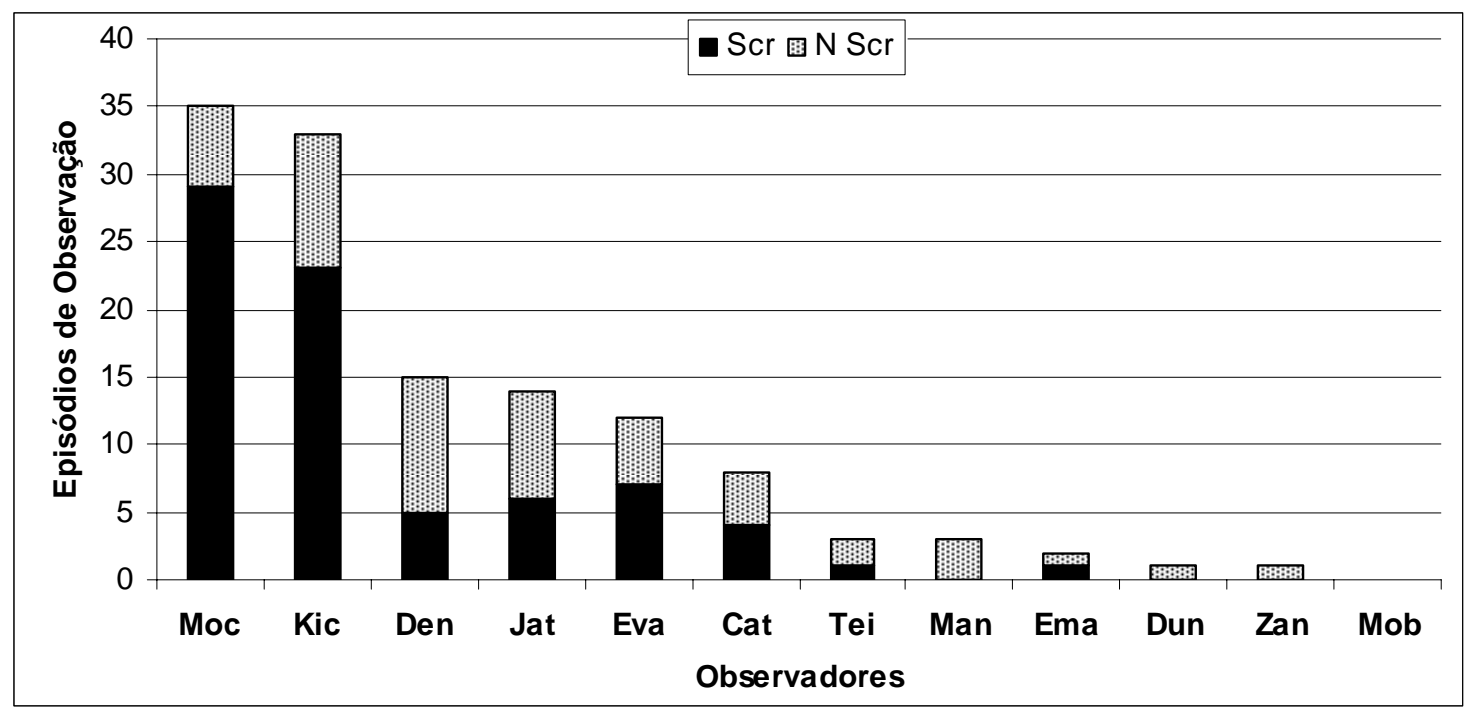

Figura 14: Episódios de Observação individual da quebra de cocos em que houve (Scr) ou não houve (N Scr) Scrounging durante todo o período da coleta de dados.

Alguns indivíduos se destacam por realizarem Scrounging na maioria dos episódios de quebra que observam (dos seus eventos observacionais Moça-Chita realizou Scrounging em 83\% e Kico em 70\%), enquanto alguns indivíduos participam muito pouco de ambas as atividades como Zangado, Moça-Branca e Dunga.

Considerando todos os indivíduos do grupo, $60 \%(\mathrm{~N}=76)$ dos eventos observacionais resultaram em Scrounging. A Figura 15 mostra a proporção entre os episódios em que cada indivíduo foi alvo de observação e a ocorrência ou não de Scrounging nestes episódios. 


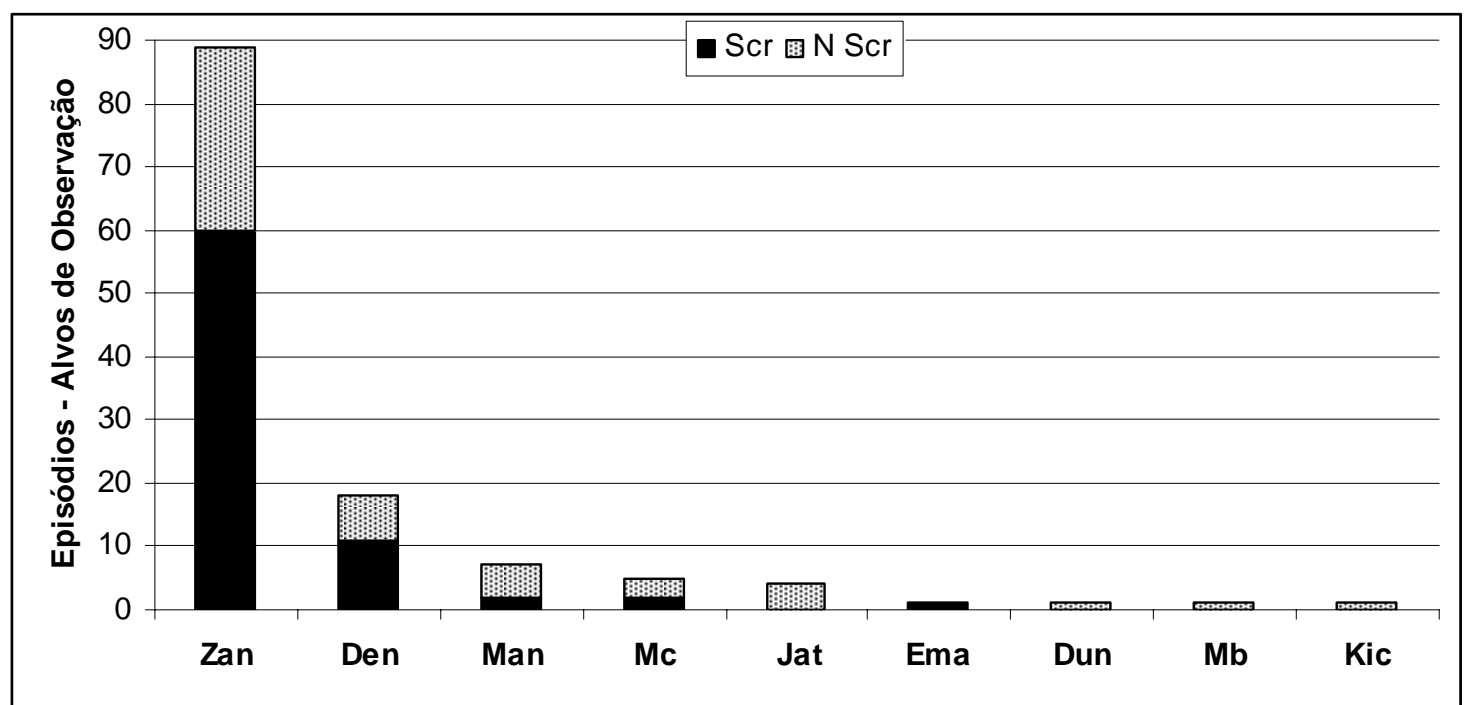

Figura 15: Episódios enquanto alvos de observação em que houve (Scr) ou não houve (N Scr) Scrounging por coespecíficos durante todo o período da coleta de dados.

Zangado (como indicado acima) foi o indivíduo mais observado e mostrou-se tolerante ao Scrounging em 67\% $(\mathrm{N}=60)$ dos episódios que foi alvo de observação.

No total, $67,5 \%(\mathrm{~N}=104)$ dos episódios de Scrounging vêm de eventos observacionais (Figura 16). O Scrounging Imediato sem observação ocorre quando um indivíduo se aproxima do sítio de quebra depois do coco já quebrado pelo coespecífico, não tendo a oportunidade de observar o comportamento de uso de ferramentas, mas ingere endosperma do coco na presença do quebrador.

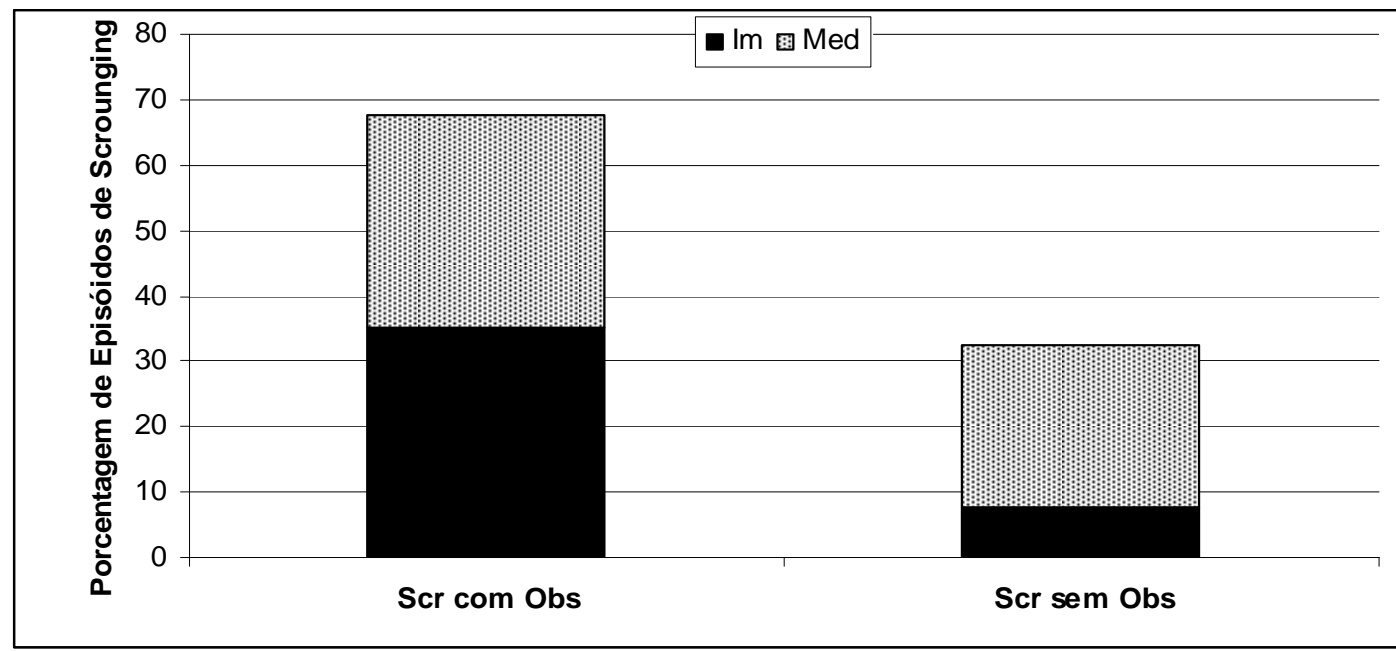

Figura 16: Porcentagem dos episódios de Scrounging que resultaram de um evento de observação. Im: Scrounging Imediato; Med: Scrounging Mediato. 


\subsubsection{Escolha do Alvo de Observação}

Para realizarmos as análises sobre a escolha do alvo de observação pelos coespecíficos, retiramos da amostra os episódios de uso de ferramentas para a quebra de cocos em que não foi possível identificar qual o resultado da quebra (QN - ver acima) e os episódios proficientes $(\mathrm{QP})$ em que não foi possível quantificar o número de cocos quebrados. Não foi possível fazer as comparações entre as matrizes de Observação e Idade, pois não tínhamos dados sobre a idade relativa da maioria dos indivíduos do Grupo do Zangado.

Verificamos se a escolha dos alvos de observação estava relacionada à proximidade e quais características dos indivíduos estariam associadas à sua escolha como alvos de observação. Para esta análise, no primeiro período, retiramos Moça Branca e Emília da amostra, já que apresentaram apenas um episódio de quebra e não observaram coespecíficos durante esta atividade. No segundo período, retiramos da análise a fêmea Dunga, pois ela esteve ausente grande parte do período, não constando das análises de proximidade, além de apresentar apenas um episódio de quebra e nenhum de observação. A Tabela 11 contém os resultados das comparações entre matrizes indicando os valores de Tau $\mathrm{Kr}$ /one-tailed rightsided $\mathrm{p}_{\mathrm{r}}($ Hemelrijk, 1990a,b)

Tabela 11: Correlações das matrizes de Observação (matriz assimétrica) com: Proximidade de 1 metro (matriz simétrica); Proximidade de 10 metros (matriz simétrica); Postos Hierárquicos (matriz hipotética); Freqüência de Quebra (matriz hipotética); Taxa de Proficiência na Quebra (matriz hipotética) e Taxa de Produtividade na Quebra (matriz hipotética). P1: primeiro período; P2: segundo período; P3: terceiro período.

\begin{tabular}{|c|c|c|c|c|c|c|}
\hline & \multicolumn{2}{|c|}{ P1* } & \multicolumn{2}{|c|}{ P2** } & \multicolumn{2}{|c|}{ P3*** } \\
\hline & Tau $K r^{1}$ & $\mathbf{p}_{\mathbf{r}}$ & $T a u K r^{1}$ & pr & $T a u K r^{2}$ & $\mathbf{p r}_{\mathbf{r}}$ \\
\hline Obs X Proximidade $1 \mathrm{~m}$ & 0,121 & 0,1704 & 0,045 & 0,4333 & 0 & 0,4638 \\
\hline Obs X Proximidade $10 \mathrm{~m}$ & 0,228 & 0,07 & 0,045 & 0,4623 & 0,162 & 0,2584 \\
\hline Obs X Postos Hierárquicos & $-0,353$ & 0,9190 & $-0,181$ & 0,7056 & $-0,417$ & 0,9625 \\
\hline Obs X Freqüência de Quebra & 0,584 & 0,005 & 0,659 & 0,0215 & 0,472 & 0,02 \\
\hline Obs X Proficiência na Quebra & 0,574 & 0,0120 & 0,561 & 0,0475 & 0,436 & 0,0425 \\
\hline Obs X Produtividade na Quebra & 0,562 & 0,0135 & 0,561 & 0,0475 & 0,436 & 0,0425 \\
\hline
\end{tabular}

${ }^{*} \mathrm{~N}$ indivíduos $=10 ; * * \mathrm{~N}$ indivíduos $=8 ; * * * \mathrm{~N}$ indivíduos $=8 ; 1$ - Partial Tau $K r=$ com controle para matriz de zeros estruturais; 2 - Tau $\mathrm{Kr}=$ sem matriz de zeros estruturais; = correlações significativas. 
Não encontramos correlações significativas entre Observação $X$ Proximidade e Observação X Postos Hierárquicos. Esses resultados se assemelham aos obtidos por Ottoni et al. (2005). Então, voltamos nossa atenção para as características relacionadas ao desempenho na quebra de cocos.

Houve correlação positiva significativa entre Observação X Freqüência de Quebra, Observação X Taxa de Proficiência e Observação X Taxa de Produtividade. Isto indica uma escolha ativa dos alvos de observação. Para confirmarmos se a escolha do indivíduo scrounger segue o mesmo padrão do observador, realizamos as mesmas correlações com as matrizes de scrounging entre os indivíduos do Grupo do Zangado. A Tabela 12 mostra os valores de Tau Kr e one-tailed right-sided $p_{\mathrm{r}}($ Hemelrijk, 1990a,b), para tais correlações.

Tabela 12: Correlações das matrizes de Scrounging (matriz assimétrica) com: Proximidade de 1 metro (matriz simétrica); Proximidade de 10 metros (matriz simétrica); Postos Hierárquicos (matriz hipotética); Freqüência de Quebra (matriz hipotética); Taxa de Proficiência na Quebra (matriz hipotética) e Taxa de Produtividade na Quebra (matriz hipotética). P1: primeiro período; P2: segundo período; P3: terceiro período.

\begin{tabular}{|c|c|c|c|c|c|c|}
\hline & \multicolumn{2}{|c|}{ P1* } & \multicolumn{2}{|c|}{$\mathbf{P} 2 * *$} & \multicolumn{2}{|c|}{$\mathbf{P} 3 * * *$} \\
\hline & Tau Kr ${ }^{1}$ & $\mathbf{p r}_{\mathbf{r}}$ & Tau $K r^{1}$ & $\mathbf{p r}_{\mathbf{r}}$ & Tau $K r^{2}$ & $\mathbf{p r}_{\mathbf{r}}$ \\
\hline Scr X Proximidade $1 \mathrm{~m}$ & 0,196 & 0,074 & 0,047 & 0,4328 & $-0,045$ & 0,4398 \\
\hline Scr X Proximidade $10 \mathrm{~m}$ & 0,227 & 0,0815 & 0,095 & 0,3918 & 0,157 & 0,3783 \\
\hline Scr X Postos Hierárquicos & $-0,531$ & 0,982 & $-0,278$ & 0,7856 & $-0,449$ & 0,9205 \\
\hline Scr X Freqüência de Quebra & 0,581 & 0,0095 & 0,726 & 0,011 & 0,537 & 0,042 \\
\hline Scr X Proficiência na Quebra & 0,635 & 0,007 & 0,617 & 0,0295 & 0,571 & 0,019 \\
\hline Scr X Produtividade na Quebra & 0,622 & 0,0105 & 0,617 & 0,0295 & 0,548 & 0,0325 \\
\hline
\end{tabular}

${ }^{*} \mathrm{~N}$ indivíduos $=10 ; * * \mathrm{~N}$ indivíduos $=8 ; * * * \mathrm{~N}$ indivíduos $=8 ; 1$ - Partial Tau $K r=$ com controle para matriz de zeros estruturais; 2 - Tau $K r=$ sem matriz de zeros estruturais; = correlações estatisticamente significativas.

Os resultados foram semelhantes aos obtidos com as matrizes de observação, confirmando que o scrounging, assim como a observação de coespecíficos-alvo, envolve uma escolha ativa dos indivíduos com maior Freqüência, Proficiência e Produtividade na quebra de coco. 
Posteriormente, verificamos se as correlações positivas encontradas entre Observação X Proficiência e Produtividade não estariam relacionadas a uma correlação entre Proficiência/Produtividade e Freqüência Absoluta de Quebra. Através do cálculo de correlações de Spearman temos que Freqüência e Taxa de Proficiência na Quebra estão muito correlacionadas nos dois primeiros períodos de coleta de dados $(\mathrm{P} 1: \mathrm{rs}=0,9345 ; \mathrm{t}=7,428 ; \mathrm{p}$ $=0,0001 / \mathrm{P} 2: \mathrm{rs}=0,9548 ; \mathrm{t}=7,8642 ; \mathrm{p}=0,0002)$, mas não se correlacionam significativamente no terceiro período ( $\mathrm{P} 3: \mathrm{rs}=0,4157 ; \mathrm{t}=1,1195 ; \mathrm{p}=0,3057)$. O mesmo ocorre entre as correlações de Freqüência e Produtividade na Quebra (P1: $r s=0,922 ; \mathrm{t}=$ 6,7351; $\mathrm{p}=0,0001 / \mathrm{P} 2: \mathrm{rs}=0,9548 ; \mathrm{t}=7,8642 ; \mathrm{p}=0,0002 / \mathrm{P} 3: \mathrm{rs}=0,4759 ; \mathrm{t}=1,3254 ; \mathrm{p}=$ 0,2332).

Para interpretar tais resultados, correlacionamos as matrizes de Proficiência e Freqüência de Quebra. Para os dois primeiros períodos encontramos correlação positiva (P1, Partial Tau $K r=0,793 ; \mathrm{p}_{\mathrm{r}}=0,001 / \mathrm{P} 2$, Partial Tau $K r=0,852 ; \mathrm{p}_{\mathrm{r}}=0,002$ ) o que indica a relação entre as duas variáveis consideradas. Já no terceiro período tais fatores não se correlacionaram significativamente $\left(\mathrm{P} 3, \mathrm{Tau} K r=0,370 ; \mathrm{p}_{\mathrm{r}}=0,1134\right)$. O mesmo foi feito entre Produtividade e Freqüência e resultados semelhantes foram encontrados, sendo a correlação estatisticamente significativa nos dois primeiros períodos (P1, Partial Tau $\mathrm{Kr}=$ 0,723; $\mathrm{p}_{\mathrm{r}}=0,003 / \mathrm{P} 2$, Partial Tau $\left.K r=0,852 ; \mathrm{p}_{\mathrm{r}}=0,002\right)$, porém não no último período (P3, Tau $\left.K r=0,444 ; \mathrm{p}_{\mathrm{r}}=0,0755\right)$.

Nos dois primeiros períodos a correlação entre Observação e Taxa de Proficiência na Quebra não foi significativa quando utilizamos a matriz de Freqüência de Quebra como terceira matriz, para controlar os possíveis efeitos da Freqüência Absoluta de Quebra sobre a Taxa de Proficiência (Partial Tau $K r=0,217 ; \mathrm{p}_{\mathrm{r}}=0,2139$ / P2: Partial Tau Kr=0,02; $\mathrm{p}_{\mathrm{r}}=$ 0,4648). O mesmo ocorreu quando correlacionamos Observação X Taxa de Produtividade utilizando a matriz de Freqüência de Quebra como controle (P1: Partial Tau Kr=0,271; $\mathrm{p}_{\mathrm{r}}=$ 0,1479 / P2: Partial Tau Kr=0,02; $\mathrm{p}_{\mathrm{r}}=0,4648$.

No entanto, quando correlacionamos as matrizes de Observação X Freqüência de Quebra, utilizando as matrizes de Proficiência como terceira matriz, os resultados foram os mesmos. P1: Partial Tau Kr=0,241; $\mathrm{p}_{\mathrm{r}}=0,1754 / \mathrm{P} 2$ : Partial Tau $K r=0,302 ; \mathrm{p}_{\mathrm{r}}=0,2124 \mathrm{O}$ mesmo ocorreu quando a terceira matriz utilizada foi a de Produtividade (P1: Partial Tau Kr= 0,29; $\mathrm{p}_{\mathrm{r}}=0,1279$ / P2: Partial Tau $\left.K r=0,302 ; \mathrm{p}_{\mathrm{r}}=0,2124\right)$. Vemos, portanto, que nos dois primeiros períodos, a variável Freqüência de Quebra está altamente correlacionada às 
variáveis Taxa de Proficiência e Taxa de Produtividade na Quebra, o que dificulta distinguir estas últimas da primeira na determinação da escolha de alvos pelos observadores. Já os resultados relativos à $\mathrm{P} 3$ apontam, como observado no estudo anterior, para uma influência efetiva do desempenho dos alvos potenciais de observação (Produtividade / Proficiência) sobre a escolha dos observadores, já que esta não pode, neste período, ser atribuída a uma conseqüência "passiva" da Freqüência de Quebra dos alvos.

Como se era esperado, durante todo o período de coleta de dados houve correlação positiva entre as matrizes de Observação e Scrounging (P1, Partial Tau Kr=0,625, $\mathrm{p}_{\mathrm{r}}=0,005$ / P2, Partial Tau Kr=0,804; $\mathrm{p}_{\mathrm{r}}=0,004$ / P3, Tau $K r=0,891 ; \mathrm{p}_{\mathrm{r}}=0,0262$ ). Isto indica que as díades de observação (alvo-observador) foram também as díades de scrounging (doadorreceptor).

\subsubsection{Escolha do Alvo de Observação: Machos e Fêmeas}

Para verificarmos a ocorrência de diferenças nos padrões de escolha dos alvos de observação em função do sexo dos alvos, refizemos as análises descritas acima, focalizando cada sexo em separado. Devido à natureza dos dados disponíveis - mais machos ativos em P1, mais fêmeas ativas em P3 - examinamos os resultados para cada sexo nestes períodos (alvos machos: dados de P1; alvos fêmeas: dados de P3).

Quando consideramos apenas os alvos machos a Observação não se correlacionou significativamente às variáveis: Postos Hierárquicos, Freqüência Absoluta de Quebra, Proficiência e Produtividade na Quebra (Tabela 13). No entanto, ao contrário dos resultados anteriores, houve correlação positiva significativa entre Observação e Proximidade entre os indivíduos (1m e 10m).

Isto significa que na análise anterior, quando incluímos todos os indivíduos-alvos do grupo, o fato das fêmeas não serem muito ativas na quebra e não serem muito observadas fez com que as correlações fossem significativamente positivas quando correlacionamos Freqüência, Proficiência e Produtividade na Quebra X Observação, já que os indivíduos machos são mais ativos e mais observados.

No entanto, quando retiramos as fêmeas da situação de alvos, a diferença entre os machos quanto àquelas variáveis é pouca: apenas Teimoso e Jatobá são menos ativos e observados na quebra. Zangado, Dengoso e Mansinho são semelhantes em Freqüência, 
Proficiência e Produtividade na Quebra e na freqüência com que foram alvos de observação, o que inviabiliza uma análise da correlação entre esses fatores. A variável importante agora é a Proximidade $(1 \mathrm{~m}$ e $10 \mathrm{~m})$ entre os indivíduos, cuja correlação com a Observação, que se mostrou significativa.

Analisando os dados relativos à observação de alvos fêmeas (P3), não encontramos correlações significativas entre Observação e nenhum dos fatores considerados (Tabela 13), o que sugere que os padrões de escolha a alvos coespecíficos anteriormente verificados para este período estariam associados à presença de Zangado, o único macho adulto remanescente no grupo.

Tabela 13: Correlações das matrizes de Observação (matriz assimétrica) com: Proximidade de 1 metro (matriz assimétrica); Proximidade de 10 metros (matriz assimétrica); Postos Hierárquicos (matriz hipotética); Freqüência de Quebra (matriz hipotética); Taxa de Proficiência na Quebra (matriz hipotética) e Taxa de Produtividade na Quebra (matriz hipotética). P1-Machos: primeiro período - somente alvos machos; P3-Fêmeas: terceiro período - somente alvos fêmeas.

\begin{tabular}{|c|c|c|c|c|}
\cline { 2 - 5 } \multicolumn{1}{c|}{} & \multicolumn{2}{c|}{ P1-Machos* $^{*}$} & \multicolumn{2}{c|}{ P3-Fêmeas** } \\
\cline { 2 - 5 } \multicolumn{1}{c|}{} & $\mathbf{T a u} \boldsymbol{K r}^{\mathbf{1}}$ & $\mathbf{p}_{\mathbf{r}}$ & $\boldsymbol{T a u}_{\boldsymbol{K} \boldsymbol{r}^{2}}$ & $\mathbf{p}_{\mathbf{r}}$ \\
\hline Obs X Proximidade 1 $\mathrm{m}$ & 0,231 & 0,0485 & 0,023 & 0,4818 \\
\hline Obs X Proximidade 10 m & 0,351 & 0,037 & 0,210 & 0,1609 \\
\hline Obs X Postos Hierárquicos & $-0,284$ & 0,4318 & $-0,257$ & 0,9515 \\
\hline Obs X Freqüência de Quebra & 0,368 & 0,8546 & 0,217 & 0,1884 \\
\hline Obs X Proficiência na Quebra & 0,391 & 0,8546 & 0,163 & 0,2899 \\
\hline Obs X Produtividade na Quebra & 0,391 & 0,8546 & 0,163 & 0,3033 \\
\hline
\end{tabular}

* $\mathrm{N}$ indivíduos $=6 ; * * \mathrm{~N}$ indivíduos $=6 ; 1$ - Partial Tau $\mathrm{Kr}=$ com controle para matriz de zeros estruturais; 2 $\mathrm{Tau} \mathrm{Kr}=$ sem matriz de zeros estruturais; = correlações estatisticamente significativas. 


\subsection{A Quebra de Outros Itens Alimentares Encapsulados}

De maio de 2006 a abril de 2007, observamos 874 episódios de uso de ferramentas, incluindo os episódios em que os indivíduos que manipularam os itens do sítio de quebra não foram identificados. A Figura 17 mostra a porcentagem do uso de ferramentas para a quebra de $\operatorname{cocos}(\mathrm{N}=668)$ e de outros itens alimentares encapsulados $(\mathrm{N}=206)$, incluindo os episódios em que o indivíduo não foi identificado.

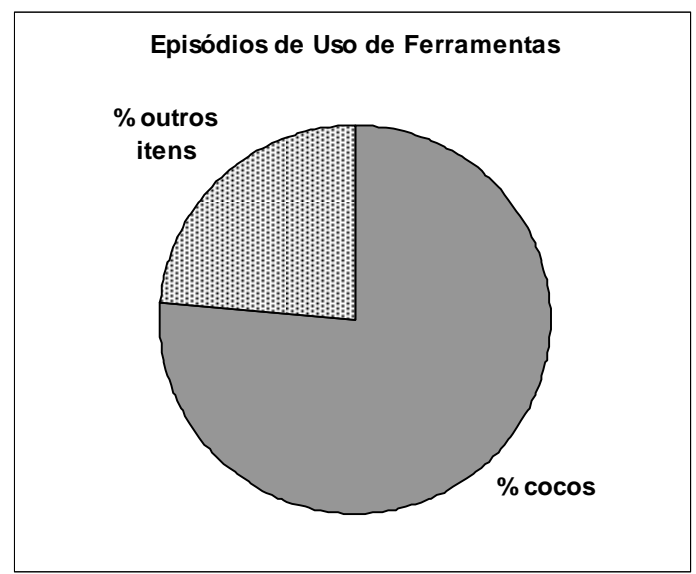

Figura 17: Porcentagem do uso de ferramentas na manipulação de cocos e outros itens alimentares encapsulados (maio de 2006 a agosto 2007).

Foram registrados, pelos métodos de Evento Focal e Todas as Ocorrências, 206 episódios de uso de ferramentas para a quebra de outros itens alimentares encapsulados (não incluindo cocos) durante todo o período de coleta de dados. A Figura 18 mostra o número de episódios relativos a estes itens, divididos em: frutos, sementes, frutos e sementes (no mesmo episódio) e itens não-identificados.

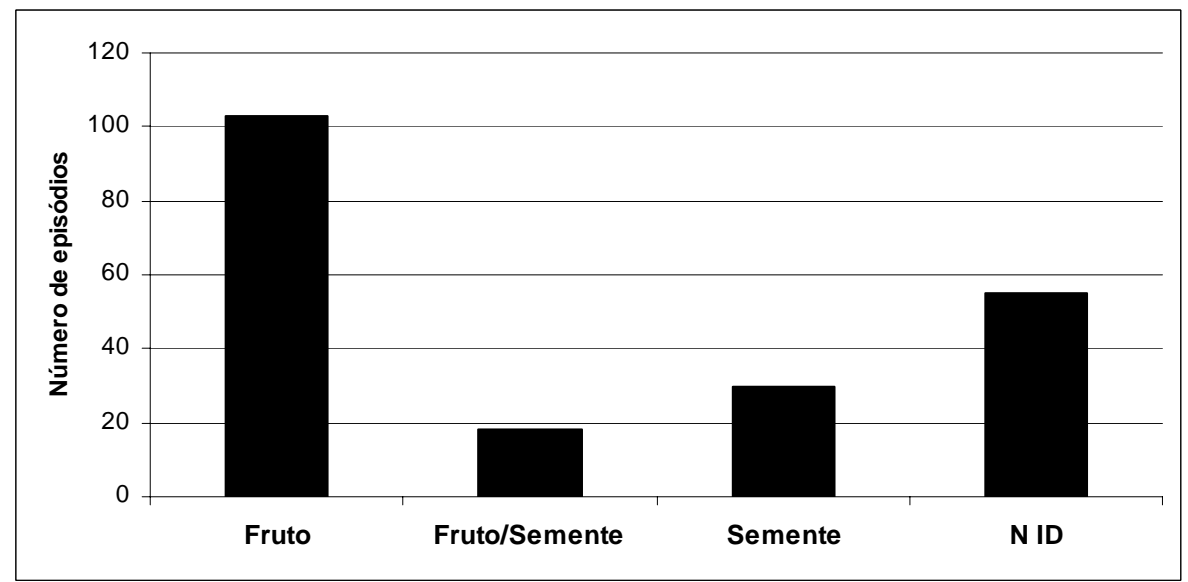

Figura 18: Número de Episódios de uso de ferramentas para quebra de frutos, frutos e sementes, sementes e itens não-identificados (N ID). 
Durante todo o período de estudo, os macacos do Grupo do Zangado foram vistos utilizando ferramentas para a quebra de 7 espécies de frutos (excluídos os cocos) e 3 espécies de sementes (houve dois episódios de quebra de fruto, e um de semente, em que não foi possível identificar a espécie). Os episódios de uso de ferramentas de itens não-identificados incluíram alguns eventos em que a manipulação não se deu exatamente para quebrar, mas sim para esmagar o material: folha de Mucambira $(\mathrm{N}=1)$, flor não identificada $(\mathrm{N}=1)$ e raiz não identificada $(\mathrm{N}=1)$. Já a castanha de caju (Anacardium sp.) e a pindaíba (Xylopia sp.) possuem substâncias tóxicas na parte externa do fruto (casca) que as tornam não palatáveis e potencialmente prejudiciais, se em contato direto com a boca. Neste caso, o rompimento da casca com o uso de ferramentas pode facilitar o acesso às partes internas e comestíveis evitando o contato direto com tais substâncias. Em relação a outros itens, como a caroba (Jacaranda sp.) e as sementes, por não termos dados sobre sua dureza, não podemos afirmar se os macacos necessitam de pedras para quebrá-los. De qualquer forma, não observamos tais itens sendo manipulados e ingeridos sem o uso de ferramentas. $\mathrm{O}$ uso de ferramentas para o forrageamento de partes de frutos de difícil acesso já foi descrito para orangotangos, em Sumatra, que utilizam gravetos curtos para a retirada de sementes do interior de frutos (Neesia sp.) que possuem pêlos urticantes (van Schaik, 1996). Este processamento descrito entre os orangotangos pode ser transmitido através de mecanismos de aprendizagem socialmente mediada (van Schaik et al., 2003). A Tabela 13 lista as espécies consumidas pelos macacos com o auxílio de ferramentas.

Tabela 13: Lista de espécies manipuladas com o uso de ferramentas pelos macacos do Grupo do Zangado durante todo período. $\mathrm{F}=$ Fruto; F/S = Fruto e Semente; Fo = Folha.

\begin{tabular}{|l|c|c|c|}
\hline \multicolumn{1}{|c|}{ Nome Popular } & Família & Espécie & $\begin{array}{c}\text { N de Episódios } \\
\text { (item acessado) }\end{array}$ \\
\hline Caroba & Bignoniaceae & Jacaranda sp. & $30(\mathrm{~F})$ \\
\hline Castanha de Caju & Anacarciaceae & Anacardium sp. & $56((\mathrm{~F})$ \\
\hline Mandioca Brava & Euphorbiaceae & não identificada & $41(\mathrm{~F} / \mathrm{S})$ \\
\hline Pequi & Caryocaraceae & Caryocar brasiliense & $3(\mathrm{~F})$ \\
\hline Pindaíba & Annonaceae & Xylopia sp. & $5(\mathrm{~F} / \mathrm{S})$ \\
\hline Sapucaia & Lecythidaceae & Eschweilera nana & $2(\mathrm{~F})$ \\
\hline Fruta d'anta & Icacinaceae & Emmotum nitens & $10(\mathrm{~S})$ \\
\hline Mucambira & Bromeliaceae & não identificada & $1(\mathrm{FO})$ \\
\hline Grão de galo & não identificada & não identificada & $1(\mathrm{~F})$ \\
\hline
\end{tabular}




\subsubsection{Demografia da Quebra de Outros Itens Encapsulados}

Excluindo os 34 episódios em que não foi possível identificar o indivíduo que utilizou ferramentas neste contexto, foram registrados 172 episódios para quebra de outros itens encapsulados. A Tabela 14 mostra, por indivíduo, o total de episódios de quebra para cada período de coleta de dados.

Tabela 14: Macacos do Grupo do Zangado que apresentaram o comportamento de quebra de itens encapsulados - não incluindo cocos (idade, sexo e número de episódios de quebra para todo o período de coleta de dados). M: Machos; F: Fêmeas; A: Adultos; S: Subadultos; J: Juvenis; I: Infantes; *: indivíduo ausente do grupo; P1: maio e junho de 2006; P2+P3: julho de 2006 a abril de 2007.

\begin{tabular}{|c|c|c|c|c|c|}
\cline { 3 - 6 } \multicolumn{2}{c}{} & \multicolumn{4}{c|}{ Episódios de Quebra } \\
\hline Indivíduo & Sexo & $\begin{array}{c}\text { Faixa } \\
\text { etária }\end{array}$ & P1 & P2+P3 & Total \\
\hline Zan & M & A & 5 & 11 & 16 \\
\hline Mob & F & A & 1 & 6 & 7 \\
\hline Ema & F & A & 8 & 6 & 14 \\
\hline Den & M & S & 4 & $*$ & 4 \\
\hline Man & M & S & 3 & $*$ & 3 \\
\hline Tei & M & J & 5 & $*$ & 5 \\
\hline Jat & M & J & 6 & $*$ & 6 \\
\hline Moc & F & A & 9 & 38 & 47 \\
\hline Dun & F & J & 4 & 13 & 17 \\
\hline Cat & F & J & 2 & 28 & 30 \\
\hline Erv & F & I & 1 & 9 & 10 \\
\hline Kic & M & I & 0 & 13 & 13 \\
\hline \multicolumn{2}{|l|}{ Total } & & 48 & 124 & 172 \\
\hline
\end{tabular}

Ao contrário do observado na quebra de cocos, Zangado $(\mathrm{N}=16)$ não foi o indivíduo mais ativo na quebra destes itens. As fêmeas juvenis Dunga $(\mathrm{N}=17)$ e Catuaba $(\mathrm{N}=30)$ se destacam nesta atividade, sendo superadas apenas pela adulta Moça-Chita $(\mathrm{N}=47)$. As Figuras 19 e 20 contêm as médias de episódios de quebra por faixa e etária e sexo, respectivamente. 


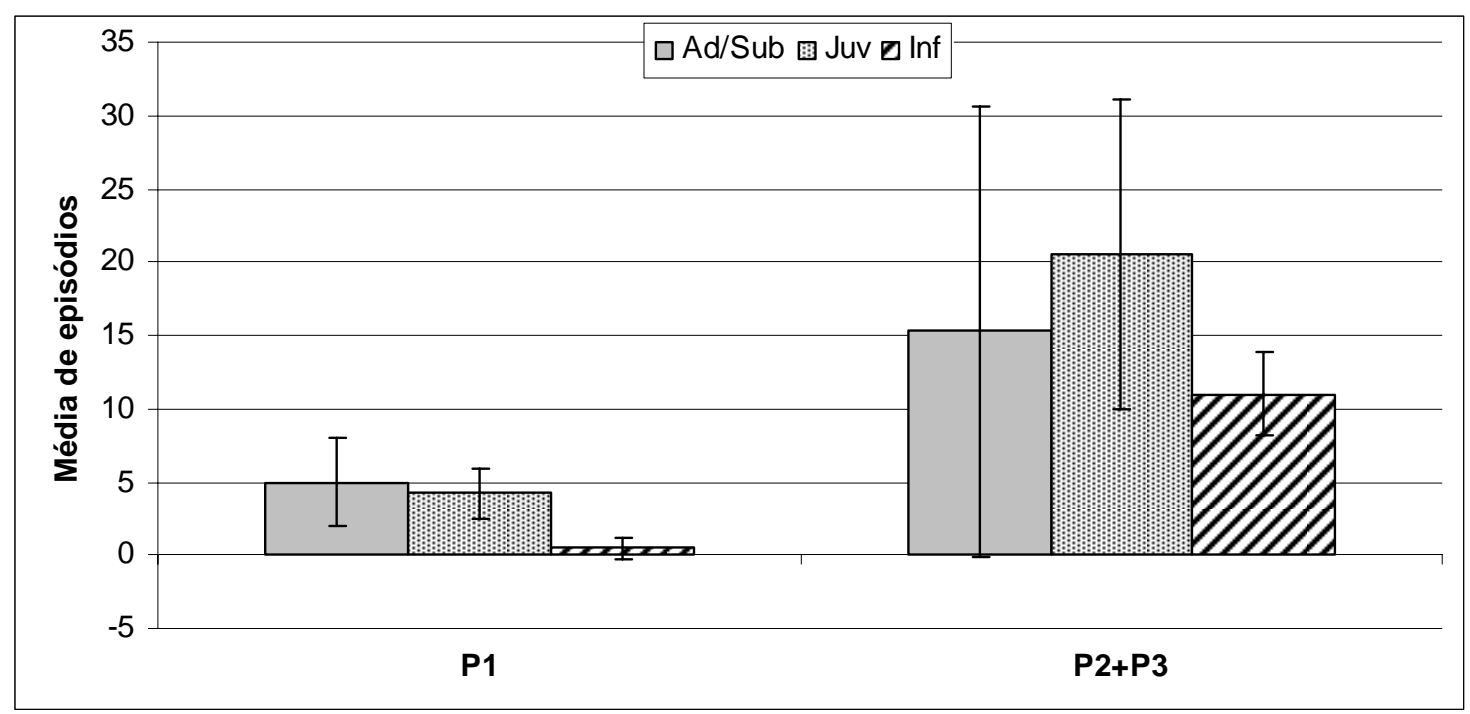

Figura 19: Média dos episódios de quebra de itens encapsulados (exceto cocos) e desviospadrão, distribuídos por faixas etárias. Ad/Sub: Adultos/Subadultos; Juv: Juvenis; Inf: Infantes; P1: Primeiro período; P2+P3: Segundo e Terceiro períodos.

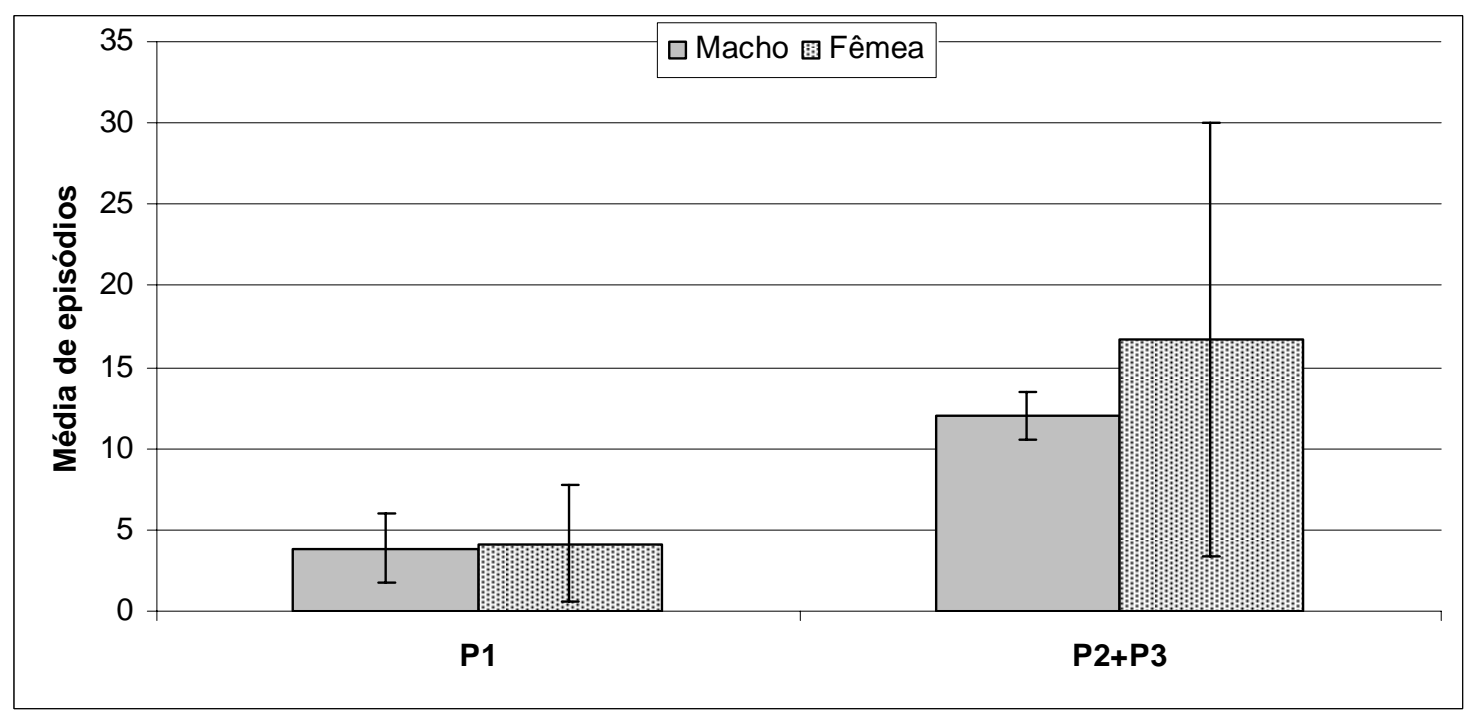

Figura 20: Média dos episódios de quebra de itens encapsulados (exceto cocos) e desviospadrão, distribuídos por sexo. Machos e Fêmeas; P1: Primeiro período; P2+P3: Segundo e Terceiro períodos. 
Houve algumas diferenças neste contexto do uso de ferramentas, em relação à quebra de cocos. Encontramos médias semelhantes de episódios entre as faixas etárias e sexos no primeiro período, o que não ocorreu com os cocos. No segundo/terceiro período, os juvenis chegam a superar os adultos/subadultos, que foram os mais ativos na quebra de cocos. Também nesta atividade as fêmeas se igualaram aos machos no primeiro período e foram um pouco mais ativas no segundo/terceiro período (devido o baixo número de machos não foi possível realizarmos a análise estatística), tendência contrária ao que ocorreu na quebra de cocos (para comparação com a quebra de cocos ver Figuras 2 e 3 ).

\subsubsection{Observação e Scrounging}

Foram registrados 22 episódios de observação por coespecíficos da quebra de itens encapsulados - exceto cocos - $(\mathrm{P} 1, \mathrm{~N}=6 ; \mathrm{P} 2, \mathrm{~N}=16)$. Assim, somente 13\% dos episódios sob este contexto $(\mathrm{P} 1=12,5 \% ; \mathrm{P} 2=13 \%)$ foram observados por outros indivíduos, sendo essa porcentagem menor do que a observação da quebra de cocos (Qui-Quadrado: $X^{2}=11,984$; G.L. $=1 ; p=0,0005)$. Zangado, como visto anteriormente para cocos, foi o indivíduo mais observado, com $50 \%$ dos episódios observados por coespecíficos.

Dos 172 episódios aqui considerados, houve scrounging em 10,5\% deles ( $\mathrm{P} 1, \mathrm{~N}=9$; P2, $\mathrm{N}=9$ ), uma porcentagem menor que a registrada no caso da quebra de cocos (QuiQuadrado: $X^{2}=20,319 ;$ G.L. $=1 ; p=0$ ). De modo idêntico ao encontrado para quebra de cocos, $67 \%$ dos episódios de scrounging por coespecíficos estão associados a eventos observacionais (Figura 21). 


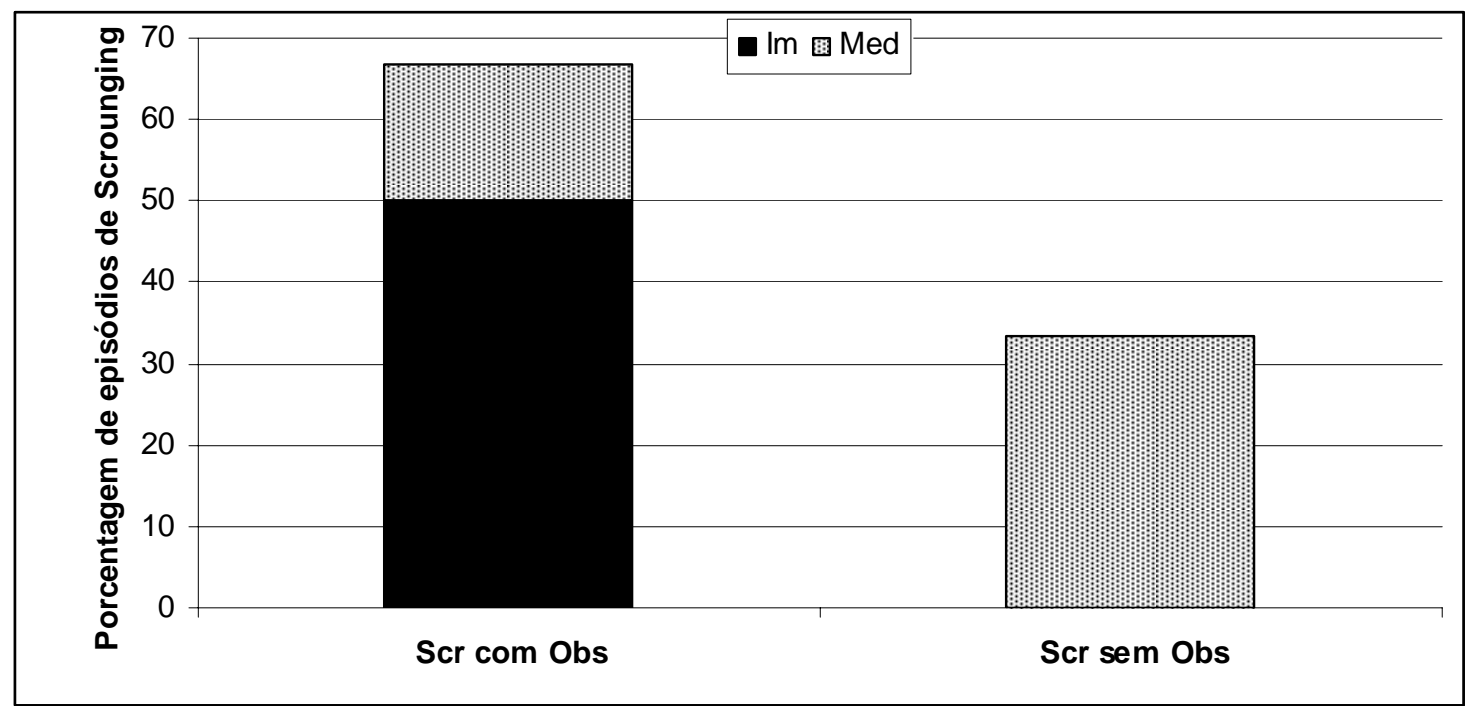

Figura 21: Porcentagem dos episódios de Scrounging que resultaram de um evento de observação. Im: Scrounging Imediato; Med: Scrounging Mediato. 


\subsection{Partilha de Alimento}

Foram registrados, durante todo o estudo, 269 episódios de Partilha de Alimento nãorelacionados aos episódios de uso de ferramentas, envolvendo frutos $(\mathrm{N}=220)$, invertebrados $(\mathrm{N}=8)$, vertebrados $(\mathrm{N}=7)$, folhas $(\mathrm{N}=10)$, raízes $(\mathrm{N}=10)$ e itens não identificados $(\mathrm{N}=$ 14). A Figura 22, mostra a proporção dos itens alimentares partilhados durante todo o período de coleta de dados (Todas as Ocorrências).

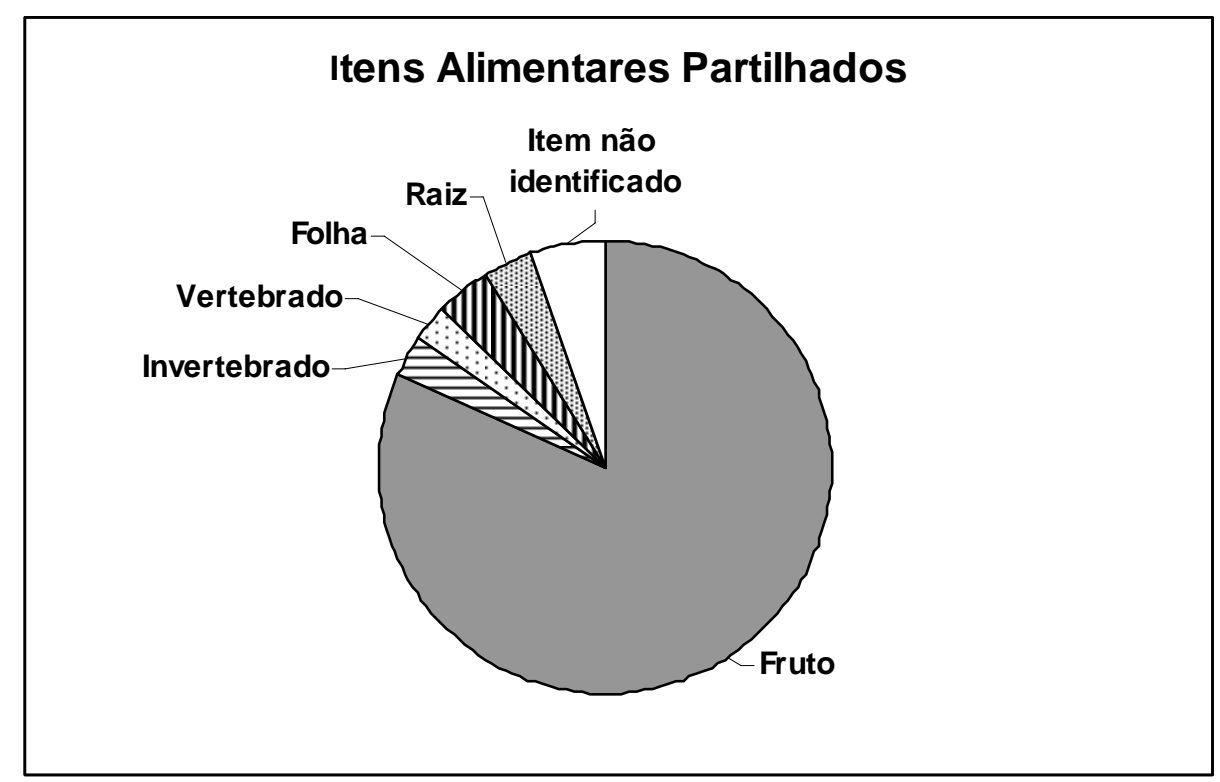

Figura 22: Itens alimentares partilhados pelo Grupo do Zangado, de maio de 2006 a abril de 2007 (método de Todas as Ocorrências).

Os frutos são o recurso alimentar mais importante na dieta dos macacos-prego. Assim, previsivelmente, foram o recurso mais partilhado entre os indivíduos do grupo $(\mathrm{N}=220$ episódios). Os cocos encontrados nas palmeiras do local de estudo, além de serem quebrados com o uso de ferramentas para obtenção do seu endosperma (como visto anteriormente) também são um importante recurso em outras fases de sua maturação, uma vez que os macacos também se alimentam de sua polpa ou "dendê" (mesocarpo) e bebem a agua contida nos cocos verdes. Dentre os frutos, a polpa dos cocos foi o item mais comumente partilhado, correspondendo a $72 \%(\mathrm{~N}=158)$ dos episódios de partilha.

Houve 13 episódios em que o doador não foi identificado pelo pesquisador, por isso estes episódios foram descartados das análises a seguir. 


\subsubsection{Demografia da Partilha de Alimento}

Registraram-se 56 episódios de Partilha de Alimento no "Grupo de Zangado" para o Primeiro Período da coleta de dados (P1). Sendo 38 por Partilha Direta e 18 por Partilha Indireta. Zangado, como doador, foi responsável por 39\% ( $\mathrm{N}=21)$ dos episódios, e Kico por $35 \%(\mathrm{~N}=19)$ como receptor. Neste primeiro período (onde foi pequeno o número de eventos), as díades mais freqüentemente observadas eram formadas pelo macho alfa e os filhotes, e não por mães e filhotes. Não temos dados sobre a história de vida de cada indivíduo, portanto não temos a confirmação do parentesco entre todos os indivíduos do grupo, somente em relação aos infantes e suas mães.

No Segundo e Terceiro Períodos, dos 200 episódios de Partilha de Alimento registrados, 89 se deram por Partilha Direta e 111, por Partilha Indireta. De modo semelhante ao verificado no período anterior, Zangado atuou como doador na maioria dos episódios registrados, sendo responsável por $42,5 \%$ destes $(\mathrm{N}=85)$ e Kico, como receptor, por $36 \%(\mathrm{~N}$ =72). A fêmea adulta Moça Chita foi o segundo indivíduo que mais participou dos episódios de Partilha de Alimento como doador ( $\mathrm{N}=52$ ); no entanto, em 52\% destes eventos, o receptor foi seu próprio filhote, o infante Café $(\mathrm{N}=27)$. (As díades observadas, assim como o total de eventos de cada sujeito, para P1 e P2+P3, estão nos Anexos G e H, respectivamente).

Aplicamos o Teste de Mann-Whitney para comparar as freqüências em que indivíduos de cada um dos sexos atuaram como doadores, tendo sido comprovada a hipótese nula de que machos e fêmeas partilharam alimento em freqüências esperadas pelo acaso durante toda a coleta de dados (Tabela 15; Mann-Whitney, P1: $U=13,50 ; Z=0,7206 ; p=0,4712$ / P2: $U=$ 6; $Z=0,7746 ; p=0,4386)$. O mesmo ocorreu quando analisamos a atuação de ambos os sexos como receptores, não havendo diferença significativa entre machos e fêmeas (MannWhitney, P1: $U=10 ; Z=1,281 ; p=0,2002$ / P2: $U=7 ; Z=0,5164 ; p=0,6056$ ).

Tabela 15: Episódios de Partilha de Alimento por coespecíficos, nos três períodos de coleta pelo método de Todas as Ocorrências, distribuídos por categorias de sexo.

\begin{tabular}{|c|c|c|c|c|c|c|c|c|c|}
\hline $\begin{array}{c}\text { Doador } \\
\text { Receptor }\end{array}$ & \multicolumn{3}{|c|}{ Macho } & \multicolumn{4}{c|}{ Fêmea } & \multicolumn{3}{c|}{ Total } \\
\cline { 2 - 11 } & $\mathrm{P} 1$ & $\mathrm{P} 2+\mathrm{P} 3$ & $\mathrm{TT}$ & $\mathrm{P} 1$ & $\mathrm{P} 2+\mathrm{P} 3$ & $\mathrm{TT}$ & $\mathrm{P} 1$ & $\mathrm{P} 2+\mathrm{P} 3$ & $\mathrm{TT}$ \\
\hline Macho & 13 & 37 & 50 & 8 & 71 & 79 & 21 & 108 & 129 \\
\hline Fêmea & 23 & 48 & 71 & 12 & 44 & 56 & 35 & 98 & 127 \\
\hline Total & 36 & 85 & 121 & 20 & 115 & 135 & 56 & 200 & 256 \\
\hline
\end{tabular}


No primeiro período, quando comparamos adultos/subadultos e juvenis quanto doadores na Partilha de Alimento, não encontramos diferença significativa entre as categorias (Mann-Whitney, P1: $U=7 ; Z=1,066 ; p=0,2864$ ). No segundo período, devido ao baixo número de juvenis e infantes, não foi possível fazer a análise estatística, no entanto, observando a Tabela 16, vemos que os adultos/subadultos são os principais doadores em ambos os períodos. No único episódio em que um infante atuou como doador, a infante Ervilha, o receptor foi o infante Kico.

Tabela 16: Episódios de Partilha de Alimento, nos três períodos de coleta pelo método de Todas as Ocorrências, distribuídos por faixa etária.

\begin{tabular}{|c|c|c|c|c|c|c|c|c|c|c|c|c|}
\hline \multirow{2}{*}{$\begin{array}{l}\text { Doador } \\
\text { Receptor }\end{array}$} & \multicolumn{3}{|c|}{ Adultos/Sub } & \multicolumn{3}{|c|}{ Juvenis } & \multicolumn{3}{|c|}{ Infantes } & \multicolumn{3}{|c|}{ Total } \\
\hline & $\mathrm{P} 1$ & $\mathrm{P} 2+\mathrm{P} 3$ & TT & $\mathrm{P} 1$ & $\mathrm{P} 2+\mathrm{P} 3$ & TT & $\mathrm{P} 1$ & $\mathrm{P} 2+\mathrm{P} 3$ & TT & $\mathrm{P} 1$ & $\mathrm{P} 2+\mathrm{P} 3$ & $\mathrm{TT}$ \\
\hline Adultos/Subadultos & 6 & 9 & 15 & 0 & 1 & 1 & 0 & 0 & 0 & 6 & 10 & 16 \\
\hline Juvenis & 8 & 24 & 32 & 4 & 0 & 4 & 0 & 0 & 0 & 12 & 24 & 36 \\
\hline Infantes & 30 & 151 & 181 & 8 & 14 & 22 & 0 & 1 & 1 & 38 & 166 & 204 \\
\hline Total & 44 & 184 & 228 & 12 & 15 & 27 & 0 & 1 & 1 & 56 & 200 & 256 \\
\hline
\end{tabular}

Apesar do pequeno número de indivíduos, que impossibilita testes estatísticos, pode-se observar que os infantes se destacam como receptores durante todo o período de coleta de dados, sendo responsáveis por $80 \%$ dos episódios de Partilha de Alimento. Para melhor visualização, as médias de episódios de Partilha de Alimento para doadores e receptores de cada faixa etária estão representadas nas Figuras 23 e 24, respectivamente. 


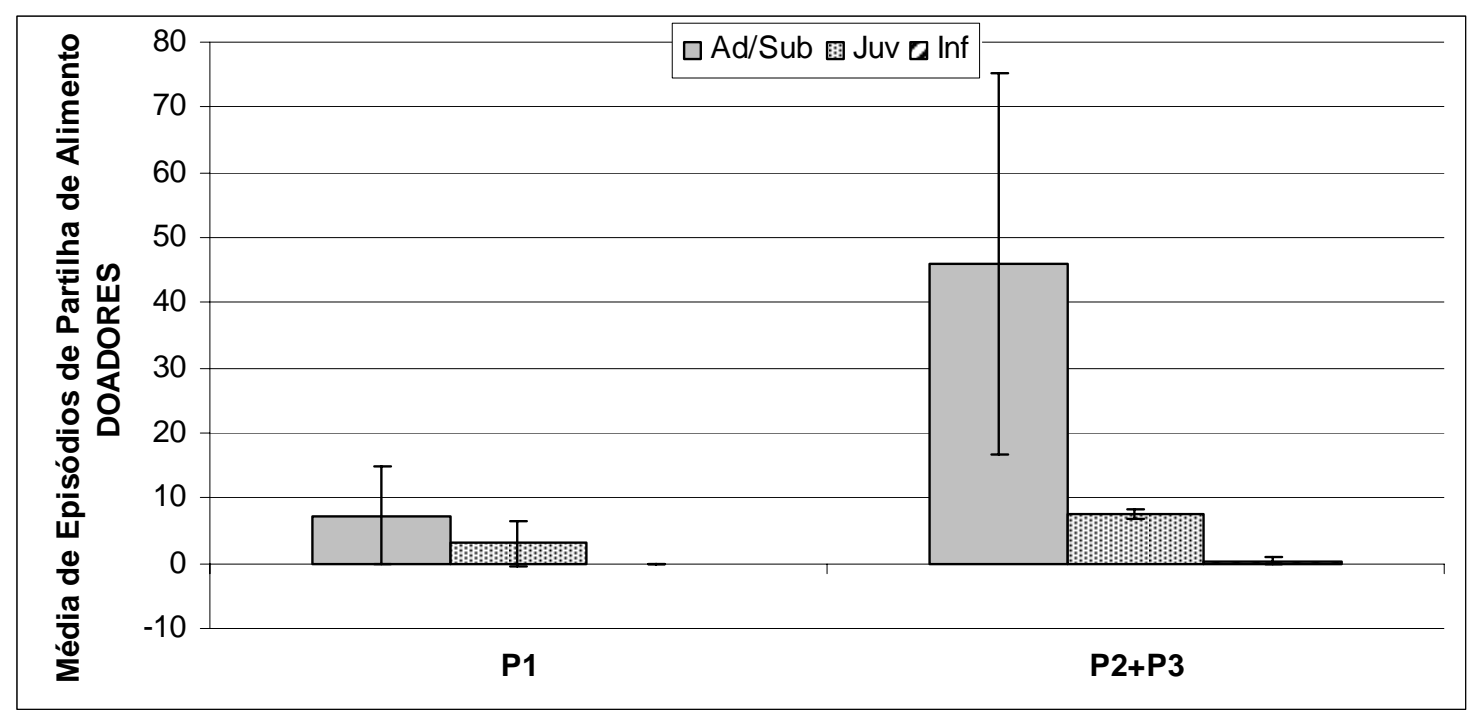

Figura 23: Média de episódios de Partilha de Alimento (e desvios-padrão) dos doadores, distribuídos entre as faixas etárias. Ad/Sub: Adultos/Subadultos; Juv: Juvenis; Inf: Infantes; P1: Primeiro período; P2+P3: Segundo e Terceiro períodos.

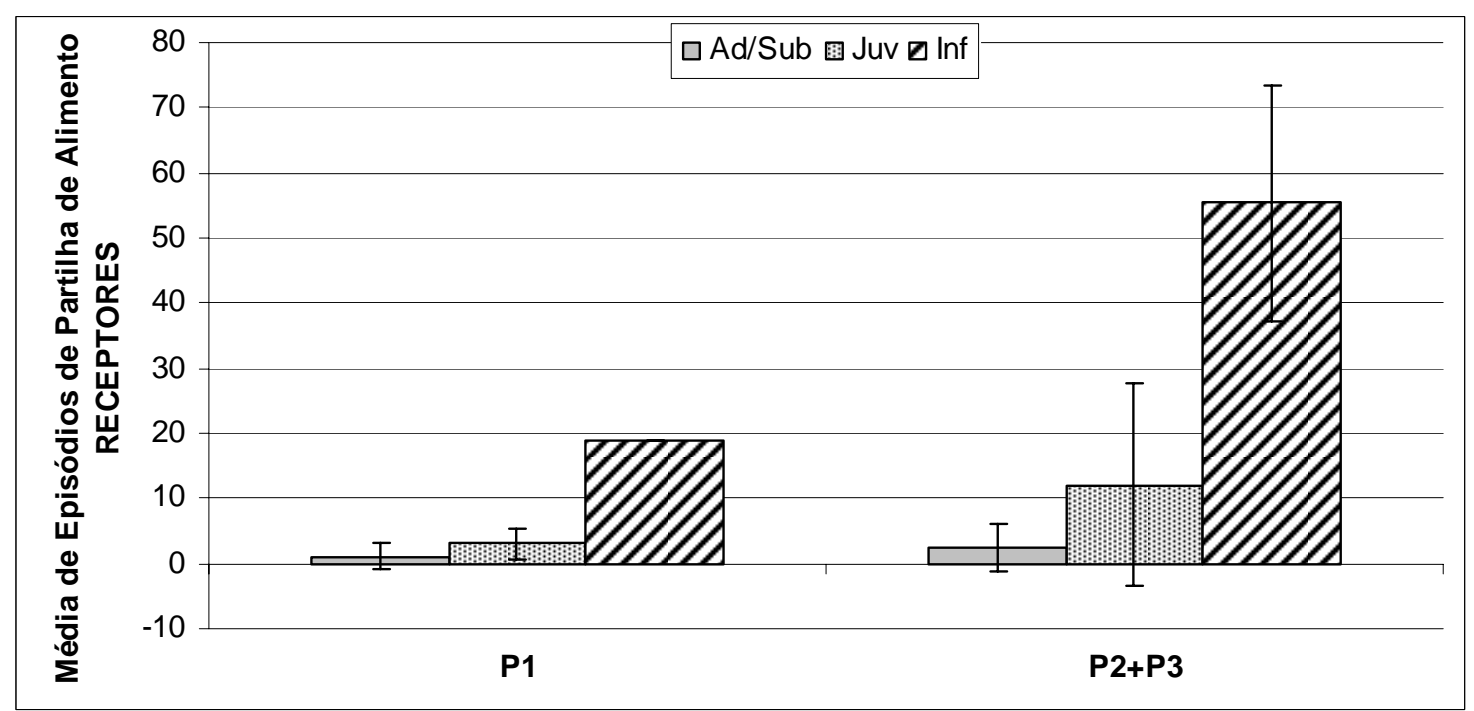

Figura 24: Média de episódios de Partilha de Alimento (e desvios-padrão) dos receptores, distribuídos entre as faixas etárias. Ad/Sub: Adultos/Subadultos; Juv: Juvenis; Inf: Infantes; P1: Primeiro período; P2+P3: Segundo e Terceiro períodos. 


\subsubsection{Partilha X Scrounging}

Para verificarmos se, ao contrário da observação e do scrounging na quebra de cocos, a Partilha de Alimento estava relacionada à proximidade entre os indivíduos e/ou a relação de hierarquia entre os mesmos, correlacionamos as matrizes de partilha conforme a Tabela 17, abaixo:

Tabela 17: Correlações das matrizes de Partilha de Alimento (matriz assimétrica) com: Proximidade de 1 metro (matriz simétrica); Proximidade de 10 metros (matriz simétrica); Postos Hierárquicos (matriz hipotética). P1: primeiro período; P2+P3: segundo e terceiro períodos.

\begin{tabular}{|c|c|c|c|c|}
\cline { 2 - 5 } \multicolumn{1}{c|}{} & \multicolumn{2}{c|}{ P1* } & \multicolumn{2}{c|}{ P2+P3** } \\
\cline { 2 - 5 } \multicolumn{1}{c|}{} & Tau $\mathbf{K r}^{\mathbf{1}}$ & $\mathbf{p r}$ & $\mathbf{T a u} \mathbf{K r}^{\mathbf{1}}$ & pr \\
\hline Partilha X Proximidade 1 m & 0,283 & 0,0135 & $-0,173$ & 0,7866 \\
\hline Partilha X Proximidade 10 m & 0,164 & 0,1219 & 0,135 & 0,3528 \\
\hline Partilha X Postos Hierárquicos & $-0,216$ & 0,8631 & $-0,558$ & 0,9895 \\
\hline
\end{tabular}

Encontramos correlação significativa somente entre Partilha de Alimento e Proximidade de 1 metro entre os indivíduos no Primeiro Período de coleta de dados. Assim como ocorreu com a observação de coespecíficos e o Scrounging na quebra de cocos, a partilha de outros tipos de alimento não sofreu influência da proximidade entre os macacos ou seus postos hierárquicos.

Verificamos se as díades da Partilha de Alimento foram as mesmas díades de Scrounging correlacionando as duas matrizes, utilizando uma terceira matriz "dummy" para controlar o efeito dos zeros estruturais. Não encontramos correlação significativa em ambos os períodos (P1, Partial Tau $K r=0,278, \mathrm{p}_{\mathrm{r}}=0,1049 / \mathrm{P} 2$, Tau $\left.K r=0,531 ; \mathrm{p}_{\mathrm{r}}=0,1381\right)$ o que indica que as díades mais freqüentes na Partilha de Alimento não foram as mesmas dos episódios de Scrounging na quebra de cocos. 


\section{Discussão}

Nos últimos anos foram desenvolvidos muitos estudos sobre o uso de ferramentas para a quebra de cocos com macacos-prego em situação de semiliberdade com provisionamento (Ottoni \& Mannu, 2001; Resende e Ottoni, 2002; Falótico, 2006; Silva \& Ottoni, 2005). No entanto, a literatura carece de dados sobre observação e scrounging da quebra por coespecíficos em ambiente selvagem. Há necessidade de comparar os dados obtidos em semiliberdade com os de animais em seu habitat natural, sem provisionamento, uma vez que a observação e o scrounging poderiam não ser tolerados de maneira semelhante. O presente estudo, por ser realizado com macacos-prego selvagens, fornece dados quantitativos para comparações com os estudos já realizados em semicativeiro.

Todos os indivíduos exibiram o comportamento de quebra de cocos (ainda que em alguns casos, apenas como Quebra Inepta), sendo este rotineiro durante todo o período de coleta de dados. Os machos foram mais ativos que as fêmeas, sendo responsáveis pela grande maioria dos episódios de quebra nos três períodos de coleta de dados, resultado semelhante ao encontrado nos trabalhos anteriores com macacos-prego em semiliberdade (Mannu, 2002; Resende, 2004) e parece ser um padrão na demografia da quebra de cocos por macacospregos.

Talvez devido ao momento em que o grupo do Parque Ecológico do Tietê se encontrava em termos de difusão do comportamento em questão, nos trabalhos anteriores ali realizados (Mannu, 2002; Resende, 2004) verificou-se que os juvenis foram os indivíduos mais ativos na quebra de cocos. No primeiro período do presente estudo, havia a presença de indivíduos subadultos bastante ativos na quebra de cocos. No restante da coleta de dados, Zangado, o macho dominante, se destaca como o indivíduo com a maior freqüência de quebra de cocos. Isto também determinou a alta freqüência de episódios de quebra dos machos.

Entre as fêmeas adultas, Moça-Chita se mostrou atípica, tanto na freqüência, quanto na proficiência e produtividade. Ela exibiu uma freqüência de quebra muito maior que as outras fêmeas adultas e a proficiência/produtividade muito menor. No entanto, apesar de não conhecermos as idades cronológicas da maioria dos indivíduos, Moça-Chita é notavelmente mais nova que as outras, portanto, menos experiente e fisicamente menor. Com o avanço da pesquisa, Moça-Chita, em desenvolvimento, melhorou seu desempenho e habilidade na quebra de cocos, mostrando-se cada vez mais proficiente. Também se nota o desenvolvimento 
do comportamento manipulativo pelos infantes e o aumento do seu interesse pela quebra de cocos, conforme foram ficando mais velhos.

No primeiro período, praticamente só machos foram observados por coespecíficos durante a quebra de cocos e houve uma preferência por observar indivíduos mais velhos, sendo o macho dominante (Zangado) o mais observado. Mesmo com a drástica queda do número de machos nos meses seguintes (migração dos quatro machos para fora do "Grupo de Zangado"), essa tendência se manteve durante toda a coleta de dados. Apesar de haver interações agonísticas (principalmente deslocamentos) durante os eventos de observação, os indivíduos se mostram muito tolerantes à observação e ao scrounging: registramos muitos episódios de Scrounging Imediato (pouco menos que de Scrounging Mediato), ou seja, em muitas situações os observadores comiam restos do coco na presença do alvo.

Indivíduos de todas as classes de idade e sexo se envolveram na observação da quebra de cocos, havendo uma enorme variação individual. As duas mães amostradas no primeiro período, Moça-Branca e Emília, apresentaram apenas um episódio de quebra cada uma e não foram observadas nem pelos seus respectivos filhotes. Assim, como visto em trabalhos anteriores em ambiente de semiliberdade (Ottoni \& Mannu, 2001), os resultados mostram que durante a quebra de cocos os macacos podem observar sujeitos com os quais exibem baixa proximidade social, porém tolerantes ao observador-scrounger. Notam-se aspectos individuais idiossincráticos no interesse pela quebra de cocos: os indivíduos Jatobá (presente somente no P1), Moça Chita e Kico se destacam pela observação da quebra em suas respectivas categorias de faixa etária. Podemos afirmar que os observadores, tolerados pelos alvos, tiveram a oportunidade de comer os restos dos cocos e de manipular os itens do sítio de quebra, tanto na ausência quanto na presença do alvo.

Pelos resultados obtidos verificamos, assim como em Ottoni et al. (2005), que o posto hierárquico não foi um fator determinante na escolha dos alvos de observação, apesar das altas taxas de observação dirigida ao macho dominante.

Com a possibilidade, já esperada, da existência de uma escolha "ativa" do alvo de observação, investigamos quais características do desempenho dos alvos em potencial seriam determinantes para que alguns macacos fossem mais observados do que outros.

Nossas análises mostram que os macacos escolhidos como alvos de observação foram aqueles que quebraram com maior Freqüência, Proficiência (mais sucesso na quebra) e obtiveram maior Produtividade de cocos. Devido à grande correlação encontrada também 
entre Observação e Freqüência Absoluta de Quebra não podemos afirmar, entretanto, como sugerido por Ottoni et al. (2005), que os observadores tenham alguma noção da proficiência dos alvos, a partir dos dados dos dois primeiros períodos de coleta de dados.

Para verificarmos se tais relações entre Observação e os fatores já considerados (Proximidade, Hierarquia, Freqüência, Proficiência e Produtividade), poderiam afetar diferentemente a escolha de alvos pelos observadores em função do sexo daqueles, refizemos as análises focalizando cada sexo-alvo em separado. Devido ao baixo número de machos presentes no grupo no Segundo e Terceiro Períodos, só foi possível calcular as correlações para os machos-alvos no Primeiro Período de coleta de dados. Através desta análise verificamos que, para essa sub-amostra, a Observação não se correlacionou com Freqüência, Proficiência ou Produtividade na Quebra, sendo significativamente correlacionada à Proximidade entre alvos e observadores. O fato de Observação ter se correlacionado com Freqüência, Proficiência e Produtividade, quando analisamos a amostra total, deve ter sido uma conseqüência da pouca participação das fêmeas - tanto como quebradoras como alvos quando comparadas aos machos, principalmente Zangado, Dengoso e Mansinho. Podemos concluir que, ao menos para uma amostra de alvos constituída por machos relativamente semelhantes no desempenho da quebra de cocos, o que afeta a taxa de observação é o quanto os observadores são próximos (distância social, conforme avaliada através das Varreduras Focais) dos alvos potenciais. No entanto, temos de deixar em aberto (pois não temos como distinguir os efeitos destas variáveis, quando incluímos na análise todos os indivíduos) o quanto estas escolhas são afetadas pelo sexo e/ou pelo desempenho dos alvos potenciais.

Os dados referentes ao terceiro período sugerem mais claramente uma escolha ativa em direção aos alvos mais proficientes e produtivos do grupo, inclusive porque aqui não encontramos correlação significativa entre a Freqüência e Proficiência/Produtividade na Quebra, que poderia confundir as correlações destas variáveis com a Observação. No entanto, quando repetimos as análises deste período apenas com as fêmeas, não encontramos correlações significativas entre Observação e nenhum dos fatores mencionados (Proximidade, Hierarquia, Freqüência, Proficiência e Produtividade). Estes resultados sugerem que os padrões de escolha a alvos coespecíficos anteriormente verificados para este período estariam associados à presença de Zangado no grupo. Este resultado já era esperado, devido à posição de Zangado como macho-alfa (na realidade, o único macho adulto presente durante esses últimos meses de coleta de dados) e quebrador mais proficiente. Esta atração preferencial ao 
macho dominante, já reconhecida sobre os macacos-prego imaturos (Resende, 2004; Sestini \& Ottoni, 1999) deve ser relevante também sobre outros indivíduos do grupo em ambiente natural. Além disso, entre as fêmeas, mesmo as adultas Moça-Branca e Emília, apesar de extremamente proficientes, raramente quebraram cocos, portanto não poderiam ser muito observadas nessa atividade.

Já sabemos que não há evidências de um interesse do macaco observador por detalhes motores do comportamento do alvo durante a quebra de cocos. Por outro lado, os observadores podem não estar necessariamente interessados nos movimentos do alvo que resultam na quebra, e sim, conforme a hipótese já mencionada inicialmente neste trabalho, eles ser atraídos para o sítio pela expectativa de poder ingerir endosperma dos cocos quebrados.

Neste contexto, nossos resultados mostram que mais da metade dos eventos de observação resultam em scrounging. Além disso, verificamos uma correlação significativa entre as díades de observação e de scrounging. Jatobá (presente somente no P1), Moça Chita e Kico, que se destacam na observação durante a quebra, também são os principais scroungers. Estes observadores mais ativos também exibiram as maiores taxas de manipulação dos itens dos sítios de quebra quando comparados a outros indivíduos de sua categoria de sexo e faixa etária, sendo que Moça Chita e Jatobá efetivamente quebraram cocos, enquanto Kico apenas se engajou na manipulação de cocos e pedras e em alguns episódios de Quebra Inepta. Estas observações reforçam a noção de que as condições e possibilidades vivenciadas pelo observador-scrounger otimizam as oportunidades para que ocorram processos de aprendizagem socialmente mediada, ao menos por realce de estímulo como sugerido por Resende (2004). Embora não tenhamos evidência de interesse dos observadores pela técnica, em si, essa exposição próxima ao comportamento do alvo poderia influenciar aspectos mais finos do comportamento dos observadores, ao longo de sua história de aprendizagem. Segundo Coussi-Korbel \& Fragaszy (1995), a informação sobre determinada atividade é mais facilmente adquirida quando o indivíduo encontra-se próximo ao outro durante a execução do comportamento. O estreitamento desta proximidade, assim como a duração e a freqüência, aumentam a probabilidade que o observador adquira informações específicas do comportamento do outro.

Seria de grande importância acompanhar o desenvolvimento da habilidade na quebra de cocos desses indivíduos, além de realizar trabalhos semelhantes focalizados na 
manipulação dos itens nos sítios (martelos e cocos) pelo observador, para verificar se os indivíduos que mais observam obtêm uma maior proficiência. No entanto, evidências da influência direta da observação na técnica do observador somente seriam verificadas se a observação mais intensiva não estiver associada a uma maior manipulação de pedras e cocos, já que indivíduos que freqüentem mais os sítios de quebra podem aprender mais individualmente, por manipular mais as pedras e cocos, e não devido à observação, ou porque sejam simplesmente mais motivados para todo esse aparato comportamental. Essa influência direta da observação no comportamento do observador poderia ser averiguada se distinguirmos variações, mesmo que sutis, na técnica da quebra de cocos. Assim, seria possível analisar se tais variantes de técnicas observadas influenciariam no aprendizado preferencial desta determinada variação na técnica de quebra, ou seja, o indivíduo observador desenvolve peculiaridades comportamentais que possam ser atribuídas à influência do seu alvo favorito. Para isso, são necessárias pesquisas de longo prazo que acompanhem diferentes indivíduos desde seus primeiros contatos com a quebra de cocos (observação e manipulação dos itens do sítio) até o momento que estes atinjam sua proficiência "ótima”, com o auxílio de técnicas precisas de registro (como filmagens).

Verificamos que há uma grande variação na proficiência entre os sujeitos do grupo e que indivíduos relativamente proficientes na quebra também observam e comem restos de cocos quebrados por outros, mais proficientes que eles. Portanto, mesmo que o indivíduo seja proficiente, pode ser mais econômico observar e comer os restos dos cocos quebrados por outro mais proficiente e produtivo.

Os cocos encontrados nas palmeiras do local de estudo, além de serem quebrados com o uso de ferramentas para obtenção do seu endosperma (como visto anteriormente) também são um importante recurso em outras fases de sua maturação, uma vez que os macacos também se alimentam de sua polpa ou "dendê" (mesocarpo). Dentre os frutos, a polpa dos cocos foi o item mais comumente partilhado entre os indivíduos do Grupo de Zangado.

Adultos e Subadultos foram os principais doadores, e os infantes, os receptores, na grande maioria dos episódios da Partilha de Alimento (exceto cocos). Verificamos algumas diferenças entre certos aspectos da Partilha de Alimento e o Scrounging na quebra de cocos. Nos episódios de Scrounging, os machos foram os principais doadores, enquanto na Partilha de Alimento, ambos os sexos participaram em freqüências esperadas pelo acaso. Isso pode ser 
explicado pela maior participação dos machos nos episódios de quebra de cocos, enquanto na Partilha de Alimentos ambos os sexos participam de maneira semelhante.

Encontramos correlação significativa entre Partilha de Alimento e Proximidade (1 metro) entre os indivíduos, no Primeiro Período de coleta de dados, o que não ocorreu em nenhum período com os episódios de Scrounging. Além disso, as díades mais freqüentes na Partilha de Alimento não foram as mesmas encontradas nos episódios de Scrounging da quebra. Isso evidencia a diferença entre a dinâmica do Scrounging de cocos e da Partilha dos outros itens alimentares utilizados pelos macacos, o que deve estar relacionado ao diferente envolvimento dos indivíduos com a quebra de cocos. Além disso, mesmo Zangado novamente se destacando como principal doador, há um grande número de episódios de Partilha de Alimento entre as díades mãe-filhote, o que não ocorre na quebra de cocos.

A quebra de outros itens alimentares encapsulados mostrou diferenças em muitos dos aspectos já levantados quanto à quebra de cocos. As fêmeas, principalmente Moça-Chita, Catuaba e Dunga, tiveram uma participação muito mais ativa na quebra destes outros itens, quando comparados com a quebra de cocos, superando inclusive o macho dominante, Zangado. Estes outros frutos encapsulados são menores e menos duros que os cocos, sendo, portanto, suficientes menos força e martelos menores e mais leves para quebrá-los. Estes itens, por serem menores, também oferecem menos material alimentar para que um indivíduo se motive a realizar o Scrounging; pelo mesmo motivo - se o Scrounging for determinante na motivação pela observação da quebra - a tolerância dos quebradores ao Scrounging também poderia ser menor. De fato, a observação e o Scrounging foram significativamente menores neste contexto do que na quebra de cocos.

O uso de ferramentas para o rompimento da casca de itens como a castanha de caju (Anacardium sp.) e a pindaíba (Xylopia sp.) parece constituir um caso distinto de abertura de frutos encapsulados com o uso de ferramentas, já que tais frutos não parecem oferecer resistência mecânica, e sim resistência química para o acesso a suas partes internas comestíveis. Como vimos, tais frutos possuem elevadas quantidades de substâncias tóxicas em sua camada externa (casca). Assim, evitar o contato contínuo destes frutos e sementes com as mãos e a boca parece ser uma estratégia de forrageamento importante, comparável ao processamento de frutos de Neesia por orangotangos (van Schaik, 1996) ou de folhas com pelos urticantes, por gorilas (Byrne \& Byrne, 1993). Seria interessante verificar se outros grupos de macacos-prego vivendo em ambiente semelhante, que ocorram os frutos descritos 
acima, também utilizam ferramentas para acessar os mesmos, já que um resultado negativo nestas condições seria um indício de que estes comportamentos constituam tradições socialmente transmitidas.

Já outros itens encapsulados, como as sementes de mandioca-brava, não parecem duros o suficiente para que haja necessidade da quebra com o uso de ferramentas. É importante que esses itens sejam analisados com a finalidade de determinar sua dureza, assim como, da relação destes com a capacidade (força) de mordida e manipulação dos pregos para verificarmos a necessidade ou não do uso de ferramenta para a abertura destes. Se essas técnicas complexas de manipulação envolvendo o uso de ferramentas, não forem realmente essenciais para que esses itens alimentares sejam acessados, também se caracterizarão como importantes objetos de estudo, dada a grande possibilidade para que sejam transmitidas socialmente, tornando-se uma tradição comportamental no grupo.

A quebra de cocos oferece ótimas oportunidades para que os indivíduos tolerados possam observar a atividade, comer os restos do coco e manipular os itens do sítio de quebra. Isto otimiza as oportunidades para que ocorra aprendizagem socialmente mediada, ao menos por realce de estímulo e local, devido à grande atração dos macacos-prego aos sítios de quebra. Trabalhos de longa duração que identifiquem, através de estudos detalhados de filmagens dos eventos de quebra, variações na técnica de quebra de cocos e acompanhem os indivíduos desde sua infância até a fase de maturação corporal necessária à quebra proficiente podem esclarecer questões como: Quanto o meio social influencia a técnica adquirida individualmente? Um indivíduo pode se tornar proficiente mais rapidamente do que outro apenas por observar mais? Se existir variantes na técnica, a observação pode influenciar na aquisição de tal variação comportamental no observador? Quais outros mecanismos de aprendizagem social, além do realce de estímulo, podem ser relevantes para a aprendizagem do uso de ferramentas? Pesquisas neste sentido trariam importantes informações para o melhor conhecimento sobre as capacidades cognitivas do macaco-prego, além de fornecerem grande contribuição nos estudos sobre aprendizagem em geral e sobre tradições comportamentais em animais não-humanos. 


\section{Anexos}

Anexo A: Episódios de observação da quebra de cocos por coespecíficos e os indivíduos envolvidos. Primeiro Período.

\begin{tabular}{|c|c|c|c|c|c|c|c|c|c|c|c|c|c|}
\hline $\begin{array}{r}\text { Alvo } \\
\text { Observador }\end{array}$ & Zan & Mob & Ema & Den & Man & Tei & Jat & Moc & Dun & Cat & Eva & Kic & Total \\
\hline Zan & 0 & 0 & 0 & 0 & 1 & 0 & 0 & 0 & 0 & 0 & 0 & 0 & 1 \\
\hline Mob & 0 & 0 & 0 & 0 & 0 & 0 & 0 & 0 & 0 & 0 & 0 & 0 & 0 \\
\hline Ema & 0 & 0 & 0 & 0 & 0 & 0 & 0 & 0 & 0 & 0 & 0 & 0 & 0 \\
\hline Den & 8 & 0 & 0 & 0 & 1 & 0 & 2 & 0 & 0 & 0 & 0 & 0 & 11 \\
\hline Man & 1 & 0 & 0 & 1 & 0 & 0 & 1 & 0 & 0 & 0 & 0 & 0 & 3 \\
\hline Tei & 2 & 0 & 0 & 0 & 3 & 0 & 0 & 0 & 0 & 0 & 0 & 0 & 5 \\
\hline Jat & 5 & 0 & 1 & 16 & 2 & 0 & 0 & 0 & 0 & 0 & 0 & 0 & 24 \\
\hline Moc & 19 & 0 & 0 & 0 & 0 & 0 & 0 & 0 & 0 & 0 & 0 & 0 & 19 \\
\hline Dun & 0 & 0 & 0 & 0 & 1 & 0 & 0 & 0 & 0 & 0 & 0 & 0 & 1 \\
\hline Cat & 1 & 0 & 0 & 1 & 1 & 0 & 0 & 0 & 0 & 0 & 0 & 0 & 3 \\
\hline Eva & 5 & 0 & 0 & 1 & 0 & 0 & 1 & 0 & 0 & 0 & 0 & 0 & 7 \\
\hline Kic & 3 & 0 & 0 & 0 & 1 & 2 & 0 & 0 & 0 & 0 & 0 & 0 & 6 \\
\hline Total & 44 & 0 & 1 & 19 & 10 & 2 & 4 & 0 & 0 & 0 & 0 & 0 & 80 \\
\hline
\end{tabular}


Anexo B: Episódios de observação da quebra de cocos por coespecíficos e os indivíduos envolvidos. Segundo Período.

\begin{tabular}{|c|c|c|c|c|c|c|c|c|c|}
\hline $\begin{array}{r}\text { Alvo } \\
\text { Observador }\end{array}$ & Zan & Mob & Ema & Den & Moc & Cat & Eva & Kic & Total \\
\hline Zan & 0 & 0 & 0 & 0 & 0 & 0 & 0 & 0 & 0 \\
\hline Mob & 0 & 0 & 0 & 0 & 0 & 0 & 0 & 0 & 0 \\
\hline Ema & 0 & 0 & 0 & 0 & 0 & 0 & 0 & 0 & 0 \\
\hline Den & 7 & 0 & 0 & 0 & 1 & 0 & 0 & 0 & 8 \\
\hline Moc & 7 & 0 & 0 & 3 & 0 & 0 & 0 & 0 & 10 \\
\hline Cat & 0 & 0 & 0 & 1 & 0 & 0 & 0 & 0 & 1 \\
\hline Eva & 3 & 1 & 0 & 2 & 0 & 0 & 0 & 0 & 6 \\
\hline Kic & 4 & 0 & 0 & 2 & 0 & 0 & 0 & 0 & 6 \\
\hline Total & 21 & 1 & 0 & 8 & 1 & 0 & 0 & 0 & 31 \\
\hline
\end{tabular}

Anexo C: Episódios de observação da quebra de cocos por coespecíficos e os indivíduos envolvidos. Terceiro Período.

\begin{tabular}{|c|c|c|c|c|c|c|c|c|c|}
\hline $\begin{array}{r}\text { Alvo } \\
\text { Observador }\end{array}$ & Zan & Mob & Ema & Moc & Dun & Cat & Eva & Kic & Total \\
\hline Zan & 0 & 0 & 0 & 0 & 0 & 0 & 0 & 0 & 0 \\
\hline Mob & 0 & 0 & 0 & 0 & 0 & 0 & 0 & 0 & 0 \\
\hline Ema & 2 & 0 & 0 & 0 & 0 & 0 & 0 & 0 & 2 \\
\hline Moc & 19 & 1 & 0 & 0 & 0 & 0 & 0 & 1 & 21 \\
\hline Dun & 0 & 0 & 0 & 1 & 0 & 0 & 0 & 0 & 1 \\
\hline Cat & 5 & 0 & 2 & 1 & 0 & 0 & 0 & 0 & 8 \\
\hline Eva & 6 & 0 & 0 & 0 & 0 & 0 & 0 & 0 & 6 \\
\hline Kic & 28 & 0 & 0 & 2 & 1 & 0 & 0 & 0 & 31 \\
\hline Total & 60 & 1 & 2 & 4 & 1 & 0 & 0 & 1 & 69 \\
\hline
\end{tabular}


Anexo D: Episódios de scrounging na quebra de cocos. Para cada receptor, estão indicados: N de Eventos de Scrounging Imediato (SI), Scrounging Mediato (SM) e Total (TT). Primeiro Período.

\begin{tabular}{|c|c|c|c|c|c|c|c|c|c|c|c|c|c|c|c|c|c|c|c|c|c|c|c|c|c|c|c|c|c|c|c|c|c|c|c|c|c|c|c|}
\hline \multirow{2}{*}{\begin{tabular}{|l|} 
Receptor \\
Doador \\
\end{tabular}} & \multicolumn{3}{|c|}{ Zan } & \multicolumn{3}{|c|}{ Mob } & \multicolumn{3}{|c|}{ Ema } & \multicolumn{3}{|c|}{ Den } & \multicolumn{3}{|c|}{ Man } & \multicolumn{3}{|c|}{ Tei } & \multicolumn{3}{|c|}{ Jat } & \multicolumn{3}{|c|}{ Moc } & \multicolumn{3}{|c|}{ Dun } & \multicolumn{3}{|c|}{ Cat } & \multicolumn{3}{|c|}{ Eva } & \multicolumn{3}{|c|}{ Kic } & \multicolumn{3}{|c|}{ Total } \\
\hline & $\mathrm{SI}$ & SM & TT & $\mathrm{SI}$ & SM & TT & $\mathrm{SI}$ & SM & TT & $\mathrm{SI}$ & SM & TT & $\mathrm{SI}$ & SM & TT & $\mathrm{SI}$ & SM & TT & $\mathrm{SI}$ & SM & TT & SI & SM & TT & $\mathrm{SI}$ & SM & TT & $\mathrm{SI}$ & SM & $\mathrm{TT}$ & $\mathrm{SI}$ & SM & $\mathrm{TT}$ & $\mathrm{SI}$ & SM & $\mathrm{TT}$ & SI & SM & TT \\
\hline Zan & 0 & 0 & 0 & 0 & 0 & 0 & 0 & 1 & 1 & 4 & 2 & 6 & 0 & 0 & 0 & 0 & 2 & 2 & 0 & 4 & 4 & 16 & 10 & 26 & 0 & + & 1 & 0 & 1 & 1 & 3 & 2 & 5 & 4 & 3 & 7 & 27 & 26 & 53 \\
\hline Mob & 0 & 0 & 0 & 0 & 0 & 0 & 0 & 0 & 0 & 0 & 0 & 0 & 0 & 0 & 0 & 0 & 0 & 0 & 0 & 0 & 0 & 0 & 0 & 0 & 0 & 0 & 0 & 0 & 0 & 0 & 0 & 0 & 0 & 0 & 0 & 0 & 0 & 0 & 0 \\
\hline Ema & 0 & 0 & 0 & 0 & 0 & 0 & 0 & 0 & 0 & 0 & 0 & 0 & 0 & 0 & 0 & 0 & 0 & 0 & 0 & 0 & $c$ & 0 & 0 & 0 & 0 & 0 & 0 & 0 & 0 & 0 & 0 & 0 & 0 & 0 & 0 & 0 & 0 & 0 & 0 \\
\hline Den & 0 & 0 & 0 & 0 & 促 & 0 & 0 & 政 & 0 & 0 & 0 & 0 & 0 & 0 & 0 & 0 & 1 & 1 & 8 & 6 & 14 & 0 & 0 & 0 & 0 & 0 & 年 & 0 & 0 & 6 & 1 & 0 & 1 & 2 & 1 & 3 & 11 & 8 & 19 \\
\hline Man & 0 & 0 & 0 & 0 & 0 & 0 & 0 & 0 & 0 & 0 & 1 & 1 & 0 & 0 & 0 & 0 & 1 & 1 & 1 & 0 & 1 & 1 & 1 & 2 & 1 & 1 & 2 & 0 & 0 & 0 & 0 & 1 & 1 & 2 & 0 & 2 & 5 & 5 & 10 \\
\hline Tei & 0 & 0 & 0 & 0 & 0 & 0 & 0 & 0 & 0 & 0 & 0 & 0 & 0 & 0 & 0 & 0 & 0 & 0 & 0 & 0 & 0 & 0 & 0 & 0 & 0 & 0 & 0 & 0 & 0 & 0 & 0 & 0 & 0 & 1 & 0 & 1 & 1 & 0 & 1 \\
\hline Jat & 0 & 0 & 0 & 0 & 0 & 0 & 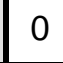 & 0 & 0 & 0 & 0 & 0 & 0 & 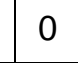 & 0 & 0 & 0 & 0 & 0 & 0 & 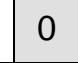 & 0 & 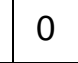 & 0 & 0 & 8 & 0 & 0 & 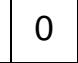 & 0 & 0 & 0 & 0 & 0 & 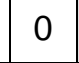 & 0 & v & 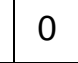 & 0 \\
\hline Moc & 0 & 0 & 0 & 0 & 0 & 0 & 0 & 0 & 0 & 0 & 0 & 0 & 0 & 0 & 0 & 0 & 0 & 0 & 0 & 0 & $c$ & 0 & 0 & 0 & 0 & 0 & 0 & 0 & 0 & 0 & 0 & 0 & 0 & 0 & 0 & 0 & 0 & 0 & 0 \\
\hline Dun & 0 & 0 & 0 & 0 & 0 & 0 & 0 & 0 & 0 & 0 & 0 & 0 & 0 & 0 & 0 & 0 & 0 & 0 & 0 & 0 & 0 & 0 & 0 & 0 & 0 & 0 & 0 & 0 & 0 & 0 & 0 & 0 & 0 & 0 & 0 & 0 & 0 & 0 & 0 \\
\hline Cat & 0 & 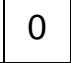 & 0 & 0 & 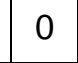 & 0 & 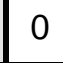 & 0 & 0 & 0 & 0 & 0 & 0 & C & 0 & 0 & 0 & 0 & 0 & 0 & 0 & 0 & 0 & 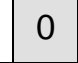 & 0 & 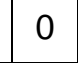 & 0 & 0 & 0 & 0 & 0 & 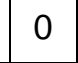 & 0 & 0 & 0 & 0 & 0 & 0 & 0 \\
\hline Eva & 0 & 0 & 0 & 0 & 0 & 0 & . & 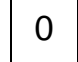 & 0 & 0 & 0 & 0 & 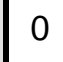 & 0 & 0 & 0 & 0 & 0 & 0 & 0 & 0 & 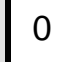 & 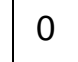 & 0 & 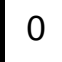 & 0 & 0 & 0 & 0 & 0 & 0 & 0 & 0 & 0 & 0 & 0 & 0 & 0 & 0 \\
\hline Kic & 0 & 0 & 0 & 0 & 0 & 0 & 0 & 0 & 0 & 0 & 0 & 0 & 0 & 0 & 0 & 0 & 0 & 0 & 0 & 0 & 0 & 0 & 0 & 0 & 0 & 0 & 0 & 0 & 0 & 0 & 0 & 0 & 0 & 0 & 0 & 0 & 0 & 0 & 0 \\
\hline Total & 0 & 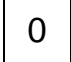 & 0 & 0 & 0 & 0 & 0 & 1 & 1 & 4 & 3 & 7 & 0 & 0 & 0 & 0 & 4 & 4 & 9 & 10 & 19 & 17 & 11 & 28 & 1 & 2 & $\checkmark$ & 0 & 1 & $\perp$ & 4 & 3 & 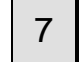 & 9 & 4 & 13 & 44 & 39 & 83 \\
\hline
\end{tabular}


Anexo E: Episódios de scrounging na quebra de cocos. Para cada receptor, estão indicados: N de Eventos de Scrounging Imediato (SI), Scrounging Mediato (SM) e Total (TT). Segundo Período.

\begin{tabular}{|c|c|c|c|c|c|c|c|c|c|c|c|c|c|c|c|c|c|c|c|c|c|c|c|c|c|c|c|}
\hline \multirow{2}{*}{\begin{tabular}{|l|} 
Receptor \\
Doador \\
\end{tabular}} & \multicolumn{3}{|c|}{ Zan } & \multicolumn{3}{|c|}{ Mob } & \multicolumn{3}{|c|}{ Ema } & \multicolumn{3}{|c|}{ Den } & \multicolumn{3}{|c|}{ Moc } & \multicolumn{3}{|c|}{ Cat } & \multicolumn{3}{|c|}{ Eva } & \multicolumn{3}{|c|}{ Kic } & \multicolumn{3}{|c|}{ Total } \\
\hline & $\mathrm{SI}$ & $S M$ & TT & $\mathrm{SI}$ & $\mathrm{SM}$ & TT & SI & $S M$ & TT & SI & $S M$ & TT & 0 & $S M$ & TT & SI & SM & TT & SI & $\mathrm{SM}$ & TT & SI & SM & TT & $\mathrm{SI}$ & $\mathrm{SM}$ & TT \\
\hline Zan & 0 & 0 & 0 & 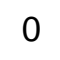 & 0 & 0 & 0 & 1 & 1 & & 0 & 2 & & 8 & 14 & 0 & & 0 & 2 & 5 & 7 & & 3 & 7 & 4 & 17 & 31 \\
\hline $\mathbf{N}$ & 0 & 0 & 0 & 0 & 0 & 0 & 0 & c & 0 & & & 0 & & & & & & 0 & 0 & O & 0 & & 0 & 0 & & 0 & 0 \\
\hline Ema & 0 & 0 & 0 & 0 & 0 & 0 & 0 & 0 & 0 & & & 0 & & & 0 & & 0 & 0 & 0 & 0 & 0 & & 0 & 0 & 0 & 0 & 0 \\
\hline Den & 0 & 0 & 0 & 0 & 0 & 0 & 0 & 0 & 0 & & 0 & 0 & & 0 & 2 & & 0 & 0 & 2 & 1 & 3 & & 1 & 3 & 6 & 2 & 8 \\
\hline Moc & 0 & 0 & 0 & 0 & 0 & 0 & 0 & 0 & 0 & & 0 & 0 & & 0 & 0 & & 0 & 0 & 0 & 0 & 0 & c & 0 & 0 & U & 0 & 0 \\
\hline Cat & 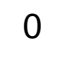 & 0 & 0 & $c$ & U & 0 & 0 & 0 & 0 & 0 & & 0 & & 0 & 0 & & 0 & 0 & 0 & 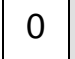 & 0 & c & 0 & 0 & 0 & 0 & 0 \\
\hline F & 0 & 0 & 0 & c & 0 & 0 & 0 & 0 & 0 & & & 0 & & c & 0 & & 0 & 0 & 0 & 0 & 0 & c & 0 & 0 & 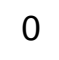 & 0 & 0 \\
\hline $\mathbf{K}$ & 0 & 0 & 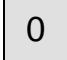 & 0 & 0 & 0 & . & 0 & 0 & 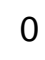 & 0 & 0 & & 0 & 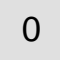 & & 0 & 0 & 0 & 0 & 0 & 0 & 0 & 0 & 0 & 0 & 0 \\
\hline Total & $v$ & 0 & 0 & 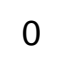 & 0 & 0 & 0 & + & $\perp$ & 0 & 0 & 2 & 0 & 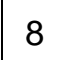 & 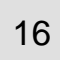 & & 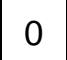 & 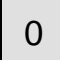 & 7 & 0 & 10 & 6 & 4 & 10 & 20 & 19 & 39 \\
\hline
\end{tabular}

Anexo F: Episódios de scrounging na quebra de cocos. Para cada receptor, estão indicados: N de Eventos de Scrounging Imediato (SI), Scrounging Mediato (SM) e Total (TT). Terceiro Período.

\begin{tabular}{|c|c|c|c|c|c|c|c|c|c|c|c|c|c|c|c|c|c|c|c|c|c|c|c|c|c|c|c|}
\hline \multirow{2}{*}{\begin{tabular}{|l|} 
Receptor \\
Doador \\
\end{tabular}} & \multicolumn{3}{|c|}{ Zan } & \multicolumn{3}{|c|}{ Mob } & \multicolumn{3}{|c|}{ Ema } & \multicolumn{3}{|c|}{ Moc } & \multicolumn{3}{|c|}{ Dun } & \multicolumn{3}{|c|}{ Cat } & \multicolumn{3}{|c|}{ Eva } & \multicolumn{3}{|c|}{ Kic } & \multicolumn{3}{|c|}{ Total } \\
\hline & $\mathrm{SI}$ & $S M$ & TT & & $\mathrm{M}$ & TT & SI & $\mathrm{SM}$ & TT & SI & SM & TT & & $\mathrm{SM}$ & TT & 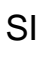 & SM & TT & SI & $\mathrm{SM}$ & $\mathrm{TT}$ & SI & $\mathrm{SM}$ & TT & SI & SM & TT \\
\hline $\mathrm{Za}$ & 0 & 0 & 0 & & 1 & 1 & 0 & 3 & 3 & 7 & 18 & 2 & & & 2 & & & 4 & 2 & 5 & 7 & 10 & 22 & 32 & 20 & 54 & 74 \\
\hline $\mathbf{N}$ & 0 & 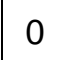 & 0 & & 0 & 0 & & & U & 0 & & 0 & & & U & & & 0 & 0 & 0 & 0 & & 0 & 0 & 0 & 0 & 0 \\
\hline $\mathbf{E}$ & 0 & 0 & 0 & 0 & 0 & 0 & 0 & 0 & 0 & 0 & 0 & 0 & & 0 & 0 & & 1 & 2 & 0 & 0 & 0 & 0 & 0 & 0 & 1 & 1 & 2 \\
\hline Moc & 0 & 0 & 0 & 0 & 0 & 0 & 0 & 0 & 0 & 0 & 0 & 0 & & 0 & 0 & & $\perp$ & 1 & 0 & 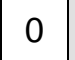 & 0 & 0 & 2 & 2 & 0 & 3 & 3 \\
\hline Dun & 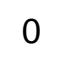 & 0 & 0 & 0 & 0 & 0 & 0 & 0 & 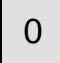 & 0 & 0 & 0 & & 0 & 0 & & 0 & 0 & 0 & 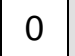 & 0 & 0 & 0 & 0 & 0 & 0 & 0 \\
\hline Cat & 0 & 0 & 0 & 0 & 0 & 0 & 0 & 0 & 0 & 0 & 0 & 0 & & 0 & 0 & & 0 & 0 & 0 & 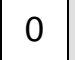 & 0 & 0 & 0 & 0 & 0 & 0 & 0 \\
\hline Eva & 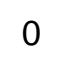 & 0 & 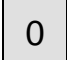 & 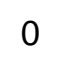 & 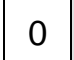 & 0 & 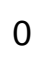 & 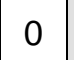 & 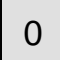 & , & 0 & 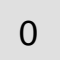 & & 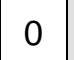 & , & & 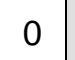 & 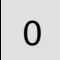 & 0 & 0 & 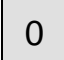 & 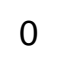 & 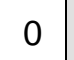 & ( & 0 & 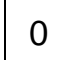 & 0 \\
\hline & , & 0 & 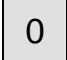 & 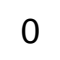 & 0 & 0 & 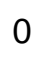 & 0 & 0 & 0 & 0 & 0 & & 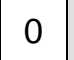 & 0 & & 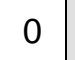 & 0 & 0 & $v$ & 0 & 0 & 0 & 0 & 0 & 0 & 0 \\
\hline HotaI & 0 & 0 & 0 & & 0 & 1 & & 0 & 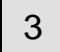 & 0 & 0 & 25 & & 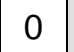 & 2 & & 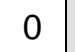 & $r$ & 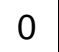 & 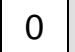 & 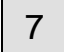 & 0 & 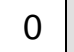 & 34 & 21 & 58 & 79 \\
\hline
\end{tabular}


Anexo G: Episódios de Partilha de Alimento. Para cada receptor: Partilha Direta (PD), Partilha Indireta (PI), Total (TT). Primeiro Período.

\begin{tabular}{|c|c|c|c|c|c|c|c|c|c|c|c|c|c|c|c|c|c|c|c|c|c|c|c|c|c|c|c|c|c|c|c|c|c|c|c|c|c|c|c|}
\hline \multirow{2}{*}{$\begin{array}{l}\text { Receptor } \\
\text { Doador } \\
\end{array}$} & \multicolumn{3}{|c|}{ Zan } & \multicolumn{3}{|c|}{ Mob } & \multicolumn{3}{|c|}{ Ema } & \multicolumn{3}{|c|}{ Den } & \multicolumn{3}{|c|}{ Man } & \multicolumn{3}{|c|}{ Tei } & \multicolumn{3}{|c|}{ Jat } & \multicolumn{3}{|c|}{ Moc } & \multicolumn{3}{|c|}{ Dun } & \multicolumn{3}{|c|}{ Cat } & \multicolumn{3}{|c|}{ Eva } & \multicolumn{3}{|c|}{ Kic } & \multicolumn{3}{|c|}{ Total } \\
\hline & PD & $\mathrm{PI}$ & TT & PD & $\mathrm{PI}$ & TT & PD & $\mathrm{PI}$ & TT & PD & $\mathrm{PI}$ & TT & PD & $\mathrm{PI}$ & TT & PD & $\mathrm{PI}$ & TT & PD & $\mathrm{PI}$ & TT & PD & $\mathrm{PI}$ & TT & PD & $\mathrm{PI}$ & $\mathrm{TT}$ & PD & $\mathrm{PI}$ & TT & PD & $\mathrm{PI}$ & TT & PD & $\mathrm{PI}$ & TT & PD & $\mathrm{PI}$ & TT \\
\hline Zan & 0 & 0 & 0 & 0 & 1 & 1 & 0 & 0 & 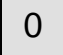 & 0 & 0 & 0 & 0 & 0 & 0 & 0 & + & + & 0 & + & 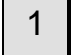 & 2 & + & 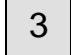 & 0 & 0 & 0 & 1 & + & 2 & 5 & 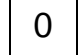 & 5 & 4 & 4 & 8 & 12 & 9 & 21 \\
\hline Mob & 0 & 0 & 0 & 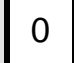 & 0 & 0 & 0 & 0 & 0 & 0 & 0 & 0 & 0 & 0 & 0 & 0 & 0 & 0 & 0 & 0 & 0 & 1 & 1 & 2 & 1 & 2 & 3 & 0 & 0 & 0 & 1 & 0 & 1 & 4 & 0 & 4 & 7 & 3 & 10 \\
\hline Ema & 0 & 0 & 0 & 0 & 0 & 0 & 0 & 0 & 0 & 0 & 0 & 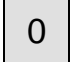 & 0 & 0 & 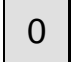 & 0 & 0 & 0 & 0 & 0 & 0 & 0 & 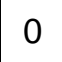 & 0 & 0 & 0 & 0 & 0 & 0 & 0 & 2 & 0 & 2 & 0 & 0 & 0 & 2 & 0 & 2 \\
\hline Den & 0 & 0 & 0 & 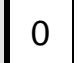 & 0 & 0 & 0 & 0 & 0 & 0 & 0 & 0 & 0 & 0 & 0 & 0 & 0 & 0 & 0 & 0 & 0 & 0 & 0 & 0 & 0 & 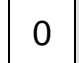 & 0 & 0 & $\perp$ & 1 & 0 & 0 & 0 & 0 & 0 & 0 & 0 & 1 & 1 \\
\hline Man & 0 & 0 & 0 & 0 & 0 & 0 & 0 & 0 & 0 & 0 & 0 & 0 & 0 & 0 & 0 & 0 & 0 & 0 & 0 & 0 & 0 & 0 & 0 & 0 & 0 & 0 & 0 & 0 & 0 & 0 & 0 & 2 & 2 & 0 & 1 & 1 & 0 & 3 & 3 \\
\hline Tei & 0 & 0 & 0 & 0 & 0 & 0 & 0 & 0 & 0 & 0 & 0 & 0 & 0 & 0 & 0 & 0 & 0 & 0 & 0 & 0 & 0 & 0 & 0 & 0 & 0 & 0 & 0 & 0 & 1 & 1 & 1 & 0 & 1 & 0 & 0 & 0 & 1 & 1 & 2 \\
\hline Jat & 0 & 0 & 0 & 0 & 0 & 0 & 0 & 0 & 0 & 0 & 0 & 0 & 0 & 0 & 0 & 0 & 0 & 0 & 0 & 0 & 0 & 0 & 0 & 0 & 1 & 0 & 1 & 0 & $\perp$ & 1 & 4 & 0 & 4 & 2 & 0 & 2 & 7 & 1 & 8 \\
\hline Moc & 0 & 0 & 0 & 0 & 0 & 0 & 0 & 0 & 0 & 0 & 0 & 0 & 0 & 0 & 0 & 0 & 0 & 0 & 0 & 0 & 0 & 0 & 0 & 0 & 0 & 0 & 0 & 0 & 0 & 0 & 3 & 0 & 3 & 4 & 0 & 4 & 7 & 0 & 7 \\
\hline Dun & 0 & 0 & 0 & 0 & 0 & 0 & 0 & 0 & 0 & 0 & 0 & 0 & 0 & 0 & 0 & 0 & 0 & 0 & 0 & 0 & 0 & 0 & 0 & 0 & 0 & 0 & 0 & 0 & 0 & 0 & 1 & 0 & 1 & 0 & 0 & 0 & 1 & 0 & 1 \\
\hline Cat & 0 & 0 & 0 & v & 0 & 0 & v & 0 & 0 & U & 0 & U & 0 & 0 & 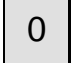 & 0 & 0 & 0 & 0 & 0 & 0 & U & 0 & 0 & 0 & 0 & 0 & 0 & 0 & 0 & 0 & 0 & 0 & 0 & 0 & 0 & 0 & 0 & 0 \\
\hline Eva & 0 & 0 & 0 & 0 & 0 & 0 & 0 & 0 & 0 & 0 & 0 & 0 & 0 & 0 & 0 & 0 & 0 & 0 & 0 & 0 & 0 & 0 & 0 & 0 & 0 & 0 & 0 & 0 & 0 & 0 & 0 & 0 & 0 & 0 & 0 & 0 & 0 & 0 & 0 \\
\hline Kic & 0 & 0 & 0 & 0 & 0 & 0 & 0 & 0 & 0 & 0 & 0 & 0 & 0 & 0 & 0 & 0 & 0 & 0 & 0 & 0 & 0 & 0 & 0 & 0 & 0 & 0 & 0 & 0 & 0 & 0 & 0 & 0 & 0 & 0 & 0 & 0 & 0 & 0 & 0 \\
\hline Total & 0 & 0 & 0 & 0 & 1 & 1 & 0 & 0 & 0 & 0 & 0 & 0 & 0 & 0 & 0 & 0 & 1 & 1 & 0 & 1 & 1 & 3 & 2 & 5 & 2 & 2 & 4 & 1 & 4 & 5 & 17 & 2 & 19 & 14 & 5 & 19 & 37 & 18 & 55 \\
\hline
\end{tabular}


Anexo H: Episódios de Partilha de Alimento. Para cada receptor: Partilha Direta (PD), Partilha Indireta (PI), Total (TT).

\begin{tabular}{|c|c|c|c|c|c|c|c|c|c|c|c|c|c|c|c|c|c|c|c|c|c|c|c|c|c|c|c|}
\hline \multirow{2}{*}{\begin{tabular}{|l|} 
Receptor \\
Doador \\
\end{tabular}} & \multicolumn{3}{|c|}{ Zan } & \multicolumn{3}{|c|}{ Mob } & \multicolumn{3}{|c|}{ Ema } & \multicolumn{3}{|c|}{ Moc } & \multicolumn{3}{|c|}{ Dun } & \multicolumn{3}{|c|}{ Cat } & \multicolumn{3}{|c|}{ Eva } & \multicolumn{3}{|c|}{ Kic } & \multicolumn{3}{|c|}{ Total } \\
\hline & PD & $\mathrm{PI}$ & TT & PD & $\mathrm{PI}$ & TT & PD & $\mathrm{PI}$ & TT & PD & $\mathrm{PI}$ & TT & PD & $\mathrm{PI}$ & TT & PD & $\mathrm{PI}$ & TT & PD & $\mathrm{PI}$ & TT & PD & $\mathrm{PI}$ & $\mathrm{TT}$ & $\mathrm{PD}$ & $\mathrm{PI}$ & TT \\
\hline Z & 0 & 0 & 0 & 1 & 0 & 1 & 0 & 1 & 1 & 2 & 5 & 7 & 0 & & 1 & 0 & 0 & 1 & 5 & 3 & 28 & 2 & 22 & 34 & 0 & 62 & 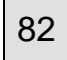 \\
\hline Mc & . & 0 & 0 & 0 & 0 & 0 & 0 & 0 & 0 & 0 & & 0 & & 0 & 0 & 0 & - & 0 & 0 & 4 & 4 & 0 & 7 & 17 & 10 & 11 & 21 \\
\hline $\mathbf{E}$ & 0 & 0 & 0 & 0 & 0 & 0 & 0 & 0 & 0 & 0 & & 0 & & 0 & 0 & 8 & 2 & 10 & 2 & 6 & 8 & 0 & 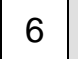 & 6 & 10 & 4 & | \\
\hline Moc & 0 & 0 & 0 & 0 & 0 & 0 & 0 & 0 & 0 & 0 & 0 & 0 & 0 & 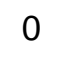 & 0 & 0 & $\checkmark$ & 3 & 4 & 9 & 13 & 4 & 6 & 9 & 7 & 8 & 25 \\
\hline Dun & 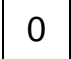 & 0 & 0 & 0 & 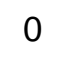 & $v$ & 0 & 0 & 0 & 0 & 0 & 0 & 0 & 0 & 0 & 0 & $\sigma$ & 0 & 0 & 1 & 1 & $?$ & 0 & 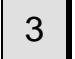 & 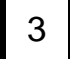 & 1 & 4 \\
\hline Cat & 0 & 0 & 0 & 0 & 0 & 0 & 0 & 0 & 0 & 1 & 0 & 1 & $v$ & 0 & 0 & 0 & 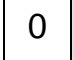 & 0 & 3 & 1 & 4 & 1 & 1 & 2 & 5 & 2 & 7 \\
\hline Eva & $v$ & 0 & 0 & 0 & 0 & 0 & 0 & 0 & 0 & 0 & 0 & 0 & 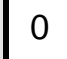 & 0 & 0 & 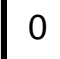 & 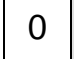 & 0 & 0 & 0 & 0 & + & 0 & 1 & 1 & 0 & 1 \\
\hline & 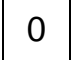 & 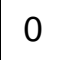 & 0 & 0 & 0 & 0 & 0 & 0 & 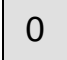 & 0 & 0 & 0 & 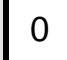 & 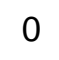 & 0 & 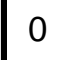 & 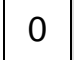 & 0 & 0 & 0 & 0 & 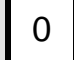 & 0 & 0 & 0 & 0 & 0 \\
\hline 1070 & 0 & 0 & 0 & 1 & 0 & 1 & 0 & 1 & 1 & 3 & 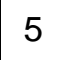 & 8 & & + & + & 8 & 15 & 2 & 14 & 44 & 58 & 30 & 42 & 72 & 56 & 1 & \\
\hline
\end{tabular}


Anexo I: Total de episódios de quebra, médias e desvios-padrão distribuídos por faixa etária para os três períodos de coleta de dados. Todas as Ocorrências + Evento Focal (Maio de 2006 a Abril de 2007).

\begin{tabular}{|c|c|c|c|c|c|c|c|c|c|c|c|c|}
\hline \multirow{3}{*}{ Faixa etária } & \multicolumn{3}{|c|}{$\begin{array}{c}\text { N de } \\
\text { Indivíduos }\end{array}$} & \multicolumn{3}{c|}{$\begin{array}{c}\text { Eventos de } \\
\text { Quebra }\end{array}$} & \multicolumn{4}{c|}{ Média } & \multicolumn{3}{c|}{ Desvio-Padrão } \\
\cline { 2 - 14 } & P1 & P2 & P3 & P1 & P2 & P3 & P1 & P2 & P3 & P1 & P2 & P3 \\
\hline Adulto/Subadulto & 6 & 5 & 4 & 261 & 74 & 160 & 43.5 & 14,8 & 40 & 42.8 & 13,68 & 47,17 \\
\hline Juvenil & 4 & 2 & 2 & 78 & 2 & 25 & 19.5 & 1 & 12,5 & 23.9 & 0 & 3,53 \\
\hline Infante & 2 & 2 & 2 & 0 & 0 & 12 & 0 & 0 & 6 & 0 & 0 & 1,41 \\
\hline
\end{tabular}

Anexo J: Total de episódios de quebra, médias e desvios-padrão distribuídos por sexo para os três períodos de coleta de dados. Todas as Ocorrências + Evento Focal (Maio de 2006 a Abril de 2007).

\begin{tabular}{|c|c|c|c|c|c|c|c|c|c|c|c|c|}
\hline \multirow{3}{*}{ Sexo } & \multicolumn{3}{|c|}{$\begin{array}{c}\text { N de } \\
\text { Indivíduos }\end{array}$} & \multicolumn{3}{c|}{$\begin{array}{c}\text { Eventos de } \\
\text { Quebra }\end{array}$} & \multicolumn{4}{c|}{ Média } & \multicolumn{3}{c|}{ Desvio-Padrão } \\
\cline { 2 - 13 } & P1 & P2 & P3 & P1 & P2 & P3 & P1 & P2 & P3 & P1 & P2 & P3 \\
\hline Machos & 6 & 3 & 2 & 322 & 58 & 114 & 53,66 & 19,33 & 57 & 35,67 & 17,21 & 70,71 \\
\hline Fêmeas & 6 & 6 & 6 & 17 & 18 & 83 & 2,83 & 3 & 13,83 & 4,07 & 3,95 & 12,87 \\
\hline
\end{tabular}

Anexo L: Episódios de observação, médias e desvios-padrão distribuídos por faixa etária para os três períodos de coleta de dados. Todas as Ocorrências + Evento Focal (Maio de 2006 a Abril de 2007).

\begin{tabular}{|c|c|c|c|c|c|c|c|c|c|c|c|c|}
\hline \multirow{2}{*}{ Faixa etária } & \multicolumn{3}{|c|}{$\begin{array}{c}\text { N de } \\
\text { Indivíduos }\end{array}$} & $\begin{array}{c}\text { Episódios de } \\
\text { Observação }\end{array}$ & \multicolumn{3}{c|}{ Média } & \multicolumn{3}{c|}{ Desvio-Padrão } \\
\cline { 2 - 15 } & P1 & P2 & P3 & P1 & P2 & P3 & P1 & P2 & P3 & P1 & P2 & P3 \\
\hline Adulto/Subadulto & 6 & 5 & 4 & 34 & 18 & 23 & 5.66 & 3,6 & 5,75 & 7.73 & 4,97 & 10,21 \\
\hline Juvenil & 4 & 2 & 2 & 33 & 1 & 9 & 8.25 & 1 & 4,5 & 10.62 & 0 & 4,95 \\
\hline Infante & 2 & 2 & 2 & 13 & 12 & 37 & 6.5 & 6 & 18,5 & 0.7 & 0 & 17,67 \\
\hline
\end{tabular}

Anexo M: Episódios de observação, médias e desvios-padrão distribuídos por sexo para os três períodos de coleta de dados. Todas as Ocorrências + Evento Focal (Maio de 2006 a Abril de 2007).

\begin{tabular}{|c|c|c|c|c|c|c|c|c|c|c|c|c|}
\hline \multirow{2}{*}{ Sexo } & \multicolumn{3}{|c|}{$\begin{array}{c}\text { N de } \\
\text { Indivíduos }\end{array}$} & $\begin{array}{c}\text { Episódios de } \\
\text { Observação }\end{array}$ & \multicolumn{4}{c|}{ Média } & \multicolumn{3}{c|}{ Desvio-Padrão } \\
\cline { 2 - 13 } & P1 & P2 & P3 & P1 & P2 & P3 & P1 & P2 & P3 & P1 & P2 & P3 \\
\hline Machos & 6 & 3 & 2 & 50 & 14 & 31 & 8.33 & 4,6 & 15,5 & 8.38 & 4,16 & 21,92 \\
\hline Fêmeas & 6 & 6 & 6 & 30 & 17 & 38 & 7.5 & 3,4 & 6,33 & 8.06 & 4,45 & 7,82 \\
\hline
\end{tabular}


Anexo N: Taxa de Proficiência (Tx Prof): Episódios proficientes (QP) dividido pelo total de episódios $(\mathrm{QP}+\mathrm{QA}+\mathrm{QP})$ por indivíduo.

\begin{tabular}{|c|c|c|c|c|c|c|c|c|c|}
\cline { 2 - 11 } \multicolumn{1}{c|}{} & \multicolumn{4}{c|}{ P1 } & \multicolumn{4}{c|}{ P2 } & \multicolumn{3}{c|}{ P3 } \\
\hline Indivíduo & QP & QP+QA+QI & Tx Prof & QP & QP+QA+QI & Tx Prof & QP & QP+QA+QI & Tx Prof \\
\hline Zan & 66 & 74 & 0.89 & 27 & 29 & 0.93 & 92 & 101 & 0.91 \\
\hline Mob & 1 & 1 & 1 & 3 & 6 & 0.5 & 5 & 8 & 0.62 \\
\hline Ema & 1 & 1 & 1 & 0 & 0 & 0 & 4 & 5 & 0.8 \\
\hline Den & 47 & 67 & 0.71 & 15 & 17 & 0.88 & - & - & - \\
\hline Man & 47 & 79 & 0.6 & - & - & - & - & - & - \\
\hline Moc & 2 & 11 & 0.18 & 1 & 6 & 0.16 & 18 & 38 & 0.47 \\
\hline Tei & 5 & 21 & 0.23 & - & - & - & - & - & - \\
\hline Jat & 18 & 48 & 0.38 & - & - & - & - & - & - \\
\hline Dun & 0 & 2 & 0 & 0 & 1 & 0 & 2 & 12 & 0.16 \\
\hline Cat & 0 & 1 & 0 & 0 & 1 & 0 & 1 & 10 & 0.1 \\
\hline Eva & 0 & 0 & 0 & 0 & 0 & 0 & 0 & 5 & 0 \\
\hline Kic & 0 & 0 & 0 & 0 & 0 & 0 & 0 & 7 & 0 \\
\hline
\end{tabular}

Anexo O: Taxa de Produtividade (Tx Prod): Número de cocos (NC) dividido pelo total de episódios (N EP).

\begin{tabular}{|c|c|c|c|c|c|c|c|c|c|}
\cline { 2 - 11 } \multicolumn{1}{c|}{} & \multicolumn{4}{c|}{ P1 } & \multicolumn{3}{c|}{ P2 } & \multicolumn{3}{c|}{ P3 } \\
\hline Indivíduo & NC & N EP & Tx Prod & NC & N EP & Tx Prod & NC & N EP & Tx Prod \\
\hline Zan & 90 & 74 & 1.216 & 34 & 25 & 1.36 & 112 & 101 & 1.089 \\
\hline Mob & 1 & 1 & 1 & 3 & 6 & 0.5 & 7 & 8 & 0.875 \\
\hline Ema & 1 & 1 & 1 & 0 & 0 & 0 & 4 & 5 & 0.8 \\
\hline Den & 58 & 67 & 0.865 & 12 & 13 & 0.923 & - & - & - \\
\hline Man & 50 & 79 & 0.639 & - & - & - & - & - & - \\
\hline Moc & 3 & 11 & 0.27 & 2 & 6 & 0.333 & 29 & 38 & 0.7631 \\
\hline Tei & 5 & 21 & 0.238 & - & - & - & - & - & - \\
\hline Jat & 21 & 48 & 0.437 & - & - & - & - & - & - \\
\hline Dun & 0 & 2 & 0 & 0 & 1 & 0 & 3 & 12 & 0.25 \\
\hline Cat & 0 & 1 & 0 & 0 & 1 & 0 & 1 & 10 & 0.1 \\
\hline Eva & 0 & 0 & 0 & 0 & 0 & 0 & 0 & 5 & 0 \\
\hline Kic & 0 & 0 & 0 & 0 & 0 & 0 & 0 & 7 & 0 \\
\hline
\end{tabular}




\section{Referências Bibliográficas}

Adams-Curtis, L. \& Fragaszy, D. M. (1995). Influence of a skilled model on the behavior of conspecific observers in tufted capuchin monkeys (Cebus apella). American Journal of Primatology, 37, 65-71.

Alp, R. (1997). "Stepping-sticks" and "seat-sticks": new types of tools used by wild chimpanzees (Pan troglodytes) in Sierra Leone. American Journal of Primatology, 41, 45-52.

Altman, J. (1974). Observational study of behaviour: sampling methods, Behaviour, 49, 223-265.

Anderson, J. R. (1990). Use of objects as hammers to open nuts by capuchin monkeys (Cebus apella). Folia Primatologica, 54, 138-145.

Beck, B. B. (1980). Animal Tool Behavior: The Use and Manufacture of Tools by Animals. New York: Garland.

Biro D., Inoue-Nakamura N., Tonooka R., Yamakoshi G., Sousa C. \& Matsuzawa T. (2003). Cultural innovation and transmission of tool use in wild chimpanzees: evidence from field experiments. Animal Cognition, 6, 213-223.

Boesch, C. (1991). Teaching among wild chimpanzees. Animal Behaviour, 41, 530-532.

Boesch, C. \& Boesch, H. (1983). Optimization of nut-cracking with natural hammers by wild chimpanzees. Behaviour, 83, 265-286.

Boesch, C., Marchesi, N., Fruth, B. and Joulian, F. (1994). Is nut cracking in wild chimpanzees a cultural behaviour? Journal of Human Evolution, 26, 325-338.

Boinski, S. (1988). Use of a club by wild white-faced capuchin (Cebus capucinus) to attack a venomous snake (Bothrops asper). American Journal of Primatology, $14,177-179$.

Breuer, T, Ndoundou-Hockemba, M. \& Fishlock, V. (2005). First observation of tool use in wild gorillas. PLoS Biology, 3(11), e380, 1-3.

Byrne, R. (1995). The thinking ape: evolutionary origins of intelligence. Oxford: Oxford University Press.

Byrne, R. W. \& Byrne, J. M. E. (1993). Complex leaf-gathering skills of mountain gorillas (Gorilla g. beringei) variability and standardization. American Journal of Primatology, 31, 241-261.

Byrne, R. W. \& Russon, A. E. (1998). Learning by imitation: a hierarquical approach. Behavioral and Brain Science, 21(5), 667-684. 
Chevalier-Skolnikoff, S. (1990). Tool use by wild Cebus monkeys at Santa Rosa National Park, Costa Rica. Primates, 31(3), 375-383.

Cooper, L. R. \& Harlow, H. F. (1961). Note on a Cebus monkey's use of a stick as a weapon. Psychological Reports, 8, 418.

Coussi-Korbel, S. \& Fragaszy, D. M. (1995). On the relation between social dynamics and social learning. Animal Behaviour, 50, 1441-1553.

Custance, D., Whiten, A., Fredman, T. (1999). Social learning of an artificial fruit task in capuchin monkey (Cebus apella). Journal of Comparative Psychology, 113 (1), 13-23.

de Waal, F. B. M. (1997). Food transfer through mesh in brown capuchins. Journal of Comparative Psychology, 111, 370-378.

de Waal, F. B. M. (2000). Attitudinal reciprocity in food sharing among brown capuchin monkeys. Animal Behaviour, 60, 253-261.

Dunbar, R. I. M. (1992). Neocortex size as a constraint on group size in primates. Journal of Human Evolution, 20, 469-493.

Fernandes, M. E. B. (1991) Tool use and predation of oysters (Crassostrea rhizophorae) by the tufted capuchin, Cebus apella apella, in brackish water mangrove swamp. Primates, 32 (4), 529-531.

Falótico, T. (2006). Estudo experimental do uso de ferramentas para a quebra de frutos encapsulados por macacos-prego (Cebus apella) em semi-liberdade. Dissertação de mestrado defendida pelo Instituto de Psicologia da Universidade de São Paulo.

Ferreira, R. G., Cavalcanti, G. C. \& Souto, A. (1996). Utilização espontânea de objeto como instrumento em macaco-prego (Cebus apella). Anais do XIV Encontro de Etologia, 385.

Fleagle, J. G. (1999). Primate Adaptations and Evolutions. Academic Press, San Diego.

Fox, E. A. \& bin'Muhammad, I. (2002). Brief Communication: New tool use by wild Sumatran orangutans (Pongo pigmaeus abelii). American Journal of Physical Anthropology, 119, 186-188.

Fragaszy, D. M. \& Adams-Curtis, L. E. (1991). Generative aspects of manipulation in tufted capuchin monkeys (Cebus apella). Journal of Comparative Psychology, 105 (4), 387-397. 
Fragaszy, D. M., Feuerstein, J, M. \& Mitra, D. (1997). Transfers of food from adults to infants in tufted capuchin (Cebus apella). Journal of Comparative Psychology, $111,194-200$.

Fragaszy, D. M. \& Perry, S. (2003). Towards a biology of traditions. In The Biology of Traditions, Models and Evidence, ed. D. Fragaszy and S. Perry, pp.1-32. Cambridge: Cambridge University Press.

Fragaszy, D. M. \& Visalberghi, E. (1989). Social influences on the acquisition of toolusing behaviors in tufted capuchin monkeys (Cebus apella). Journal of Comparative Psychology, 103(2), 159-170.

Fragaszy, D. M. \& Visalberghi, E. (1990). Social processes affecting the appearance of innovative behaviors in capuchin monkeys (Cebus apella). Folia Primatologica, $54,155-165$.

Fragaszy, d. M. \& Visalberghi, E. (2001). Recognizing a swan: socially-biased learning. Psychologia, 44, 82-98.

Fragaszy, D. M., Visalberghi, E. \& Robinson, J. G. (1990). Variability and Adaptability in the genus Cebus. Folia Primatologica, 54, 114-118.

Fragaszy, D., Visalberghi, E., Fedigan, L. (2004a). The Complete Capuchin. Cambridge University Press, UK.

Fragaszy, D. M., Izar, P., Visalberghi, E., Ottoni, E. B. \& Oliveira, M. G. (2004b). Wild capuchin monkeys (Cebus libidinosus) use anvils and stone pounding tools. American Journal of Primatology, 64, 359-356.

Fragaszy, D. M., Vitale, A. F. \& Ritchie, B. (1994). Variation among juvenile capuchins in social influences on exploration. American Journal of Primatology, $32,249-260$.

Fredman, T. \& Whiten, A. (2008). Observational learning from tool using models by human-reared and mother -reared capuchin monkeys (Cebus apella). Animal Cognition, 11, 295-309.

Goodall, J. (1990). Uma Janela para a vida: 30 anos com os chimpanzés da Tanzânia. Rio de Janeiro: Jorge Zahar Editor.

Helmerijk, C. (1990a). Models of, and test for, reciprocity, unidirectionality and other social interaction patterns at group level. Animal Behaviour, 39, 1013-1029.

Helmerijk, C. (1990b). A matrix partial correlation test used in investigations of reciprocity and other social interaction patterns at group level. Journal of Theoretical Biology, 143, 405-420. 
Henschel, J.R. (1995). Tool use by spiders: stone selection and placement by corolla spiders Ariadna (Segestriidae) of the Namib desert. Ethology, 101, 187-199.

Heyes, C. M. (1993). Imitation, culture and cognition. Animal Behaviour., 46, 9991010.

Hunt, G. R. (1996). Manufacture and use of hook-tools by New Caledonian crows. Nature, 379, 249-251.

Inoue-Nakamura, N. \& Matsuzawa, T. (1997). Development of stone tool use by wild chimpanzees (Pan troglodytes). Journal of Comparative Psychology, 111(2), 159-173.

Izar, P. Japiassu, H. F. \& Alberts, C. C. (2005). Método da teoria dos grafos para análise quantitativa do comportamento. In: Etologia, uma perspectiva histórica e tendências contemporâneas, orgs. A. Garcia, Rosana S. Tokumaru, Eliseu B. Borloti, pp 249-258. Editora Vitória: Multiplicidade.

Izawa, K. (1980). Social behavior of the wild black-capped capuchin (Cebus apella). Primates, 21, 443-467

Izawa, K. \& Mizuno, A. (1977). Palm-fruit cracking behavior of wild black-capped capuchin (Cebus apella). Primates, 18 (4), 773-792.

Janson, C. H. (1988). Food competion in brown capuchin monkeys (Cebus apella): quantitative effects of group size and tree productivity. Behaviour, 105, 53-76.

King, B. J. (1991). Social information transfer in monkeys, apes and hominids. Yearbook of Physical Anthropology, 34, 97-115.

King, B. J. (1986). Extrative foraging and the evolution of primate intelligence. Human Evolution, 1, 361-372.

Langguth, A. \& Alonso, C. (1997). Capuchin monkeys in the Caatinga: Tool use and food habits during drought. Neotropical Primates, 5 (3), 77-78.

Limongelli, L., Boysen, S. T., Visalberghi, E. (1995). Comprehension of cause-effect relations in a tool-using task by chimpanzees (Pan troglodytes). Journal of Comparative Psychology. 109 (1), 18-26.

Mannu, M. (2002). O uso espontâneo de ferramentas por macacos-prego (Cebus apella) em condições de semi-liberdade: descrição e demografia. Dissertação de mestrado defendida pelo Instituto de Psicologia da Universidade de São Paulo.

Mannu, M. \& Ottoni, E. B. submetido.

Martin, P. \& Bateson, P. (1993). Measuring behavior - an introductory guide. Cambridge: Cambridge University Press. 
Matsuzawa, T. (1994). Field experiments on use of stone tools by chimpanzees in the wild. Em R. W. Wrangham, W. C. McGrew, F. B. M. de Waal \& P. G. Heltne (eds.), Chimpanzee Cultures (351-370). Cambridge: Harvard University Press.

McGrew, W. C. (1992). Chimpanzee material culture. Cambridge: Cambridge University Press.

Moura, A. C. A. \& Lee, P. (2005). Capuchin stone tool use in caatinga dry forest. Science, 306, 1909.

Ottoni, E. B. \& Mannu, M. (2001). Semifree-ranging tufted capuchins (Cebus apella) Spontaneously use tools to crack open nuts. International Journal of Primatology, 22 (3), 347-357.

Ottoni, E. B. \& Izar, P. Towards a map of capuchin monkey' tool use: overview and implications. Evolutionary Anthropology, no prelo.

Ottoni, E. B., Resende, B. D. \& Izar, P. (2005). Watching the best nutcracking: what capuchin monkeys (Cebus apella) know about other's tool using skills. Animal Cogntion, 24, 215-219.

Panger, M. A. (1998). Object-use in free-ranging white-faced capuchins (Cebus capucinus) in Costa Rica. American Journal of Physical Anthropology, 106, 311-321.

Panger, M. A., Perry, S., Rose, L., Gros-Louis, J., Vogel, E., Mackinnon, K. C. \& Baker, M. (2002). Cross-Site differences in foraging behavior of white-faced capuchins (Cebus capucinus). American journal of physical anthropology, 119, $52-66$.

Parker, S. T. \& Gibson, K. R. (1977). Object manipulation, tool use and sensorimotor intelligence as feeding adaptations in Cebus Monkeys and Great apes. Journal of Human Evolution, 6, 623-641.

Perry, S. \& Rose, L. (1994). Begging and transfer of coati meat by white-faced capuchin monkeys, Cebus capucinus. Primates, 35, 409-415.

Perry, S., Baker, M., Fedigan, L., Gros-Louis, J., Jack, K., MacKinnon, K., C., Manson, J., H., Panger, M., Pyle, K. \& Rose, L. (2003). Social conventions in wild whitefaced capuchin monkeys: evidence for traditions in a neotropical primates. Current anthropology, 44 (2), 241-268.

Phillips, K. A. (1998). Tool use in Wild capuchins monkeys (Cebus albigrons trinitatis). American Journal of Primatology, 46, 259-291. 
Pruetz, J. D. \& Bertolani, P. (2007). Savanna chimpanzees, Pan troglodytes verus, hunt with tools. Current Biology, 17, 1-6.

Resende, B. D. (1999). Estudo dos processos de aprendizagem individual e social em macacos-prego (Cebus apella) a partir da manipulação de uma caixa-problema. Dissertação de mestrado defendida pelo Instituto de Psicologia da Universidade de São Paulo.

Resende, B. D. (2004). Ontogenia de comportamentos manipulativos em um grupo de macacos-prego (Cebus apella) em situação de semi-liberdade. Tese de Doutorado apresentado ao Instituto de Psicologia da Universidade de São Paulo.

Resende, B. D. \& Ottoni, E. B. (2002). Ontogeny of nutcracking behaviour in a semifree-ranging group of tufted capuchin monkeys. Abstract of the XIXth Congress of the International Primatology Society, 319-320.

Resende, B. D., Ottoni, E. B. \& Fragaszy, D. Ontogeny of manipulative behavior and nut-cracking in young capuchin monkeys (Cebus apella): a Perception-Action perspective. American Journal of Primatology, no prelo.

Rocha, V. J., Reis, N. R. \& Sekiama, M. L. (1998). Uso de ferramentas por Cebus apella (Linnaeus) (Primates, Cebidae) para obtenção de larvas de coleóptera que parasitam sementes de Syagrus romanzoffianum (Cham.) Glassm. (Arecaceae). Revista brasileira de Zoologia. 15 (4), 945-950.

Rose, L. M. (1997). Vertebrate predation and food-sharing in Cebus and Pan. International Journal of Primatology, 18, 727-766.

Russon, A. E. \& Galdikas, B. M. F. (1993). Imitation in free-ranging rehabilitant orangutans (Pongo pygmaeus). Journal of Comparative Psychology, 107 (2), 147-161.

Savage-Rumbaugh, S. \& Lewin, R. (1994). Kanzi, the ape at the brink of human mind. New York: John Wiley \& Sons.

Shettleworth, S. J. (1998). Cognition, Evolution, and Behavior. New York: Oxford University Press.

Silva, E. D. R. \& Ottoni, E. B (2005). O uso de ferramentas na quebra de cocos por macacos-prego (Cebus apella) em semi-liberdade no Parque Estadual do Jaraguá, SP. Anais do XXIII Encontro Anual de Etologia.

Silva Junior, J. S. (2001). Especiação em macacos-prego e caiararas, gênero Cebus Erxleben, 1777 (Primates, Cebidae). Rio de Janeiro, 377 p. Tese (Doutorado em Genética), Curso de Pós-Graduação em Genética, UFRJ. 
Sestini, A. E. \& Ottoni, E. B. (1999). Estrutura social, manipulação de objetos e processos atencionais no infante em macacos-prego (Cebus apella). Anais de Etologia, 17, 117.

Sterling, E. J. \& Povinelli, D, J. (1999). Tool use, Aye-ayes, and Sensorimotor Intelligence. Folia Primatologica, 70, 8-16.

Struhsaker, T. T. \& Leland, L. (1977). Palm-nut smashing by Cebus a. apella in Colômbia. Biotropica, 9, 124-126.

Tomasello, M. \& Call, J. (1997). Primate Cognition. Oxford University Press, Oxford. van Lawick-Goodall, J. (1970). Tool-using in primates and other vertebrates. Advance in the Studies of Behaviour, 3, 195-249.

van Schaik, C.P., Fox, E. A. \& Sitompul, A. F. (1996). Manufacture and of tools in wild Sumatran orangutans. Naturwissenschaften, 83, 186-188.

van Schaik, C. P., Deaner, R. O. \& Merril, M. Y. (1999). The conditions for tool use in primates: implications for the evolution of material culture. Journal of Human Evolution, 36, 719-741.

van Schaik, C. P., Ancrenaz, M., Borgen, G., Galdikas, B., Knott, C. D., Singleton, I., Suzuki, A., Utami, S. S. \& Merrill, M. (2003). Orangutan cultures and the evolution of material culture. Science, 299, 102-105.

Visalberghi, E. \& Adessi, E. (2003). Food for thought: social learning about food in feeding capuchin monkeys. In The Biology of Traditions, ed. D. M. Fragaszy and S. Perry, pp. 187-212. Cambridge University Press.

Visalberghi, E., Fragaszy, D. M. \& Savage-Rumbaugh, S. (1995). Performance in a tool using task by common chimpanzee (Pan troglodytes), bonobos (Pan paniscus), an orangutan (Pongo pygmaeus) and capuchin monkeys (Cebus apella). Journal of Comparative Psychology, 109 (1), 52-60.

Visalberghi, E. \& Limongelli, L. (1994). Acting and understanding: tool use through the minds of capuchin monkeys. Em A. E. Russon, K. A. Bard \& S. T. Parker (eds.), Reaching in thought. The minds of the the great apes (1-39). Cambridge: Cambridge University Press.

Visalberghi, E. \& Mc Grew, W. C. (1997). Cebus meets Pan. International Journal of Primatology, 18, 677-681.

Visalberghi, E. Fragaszy, D. M., Ottoni, E., Izar, P., Oliveira, M. G. \& Andrade, F. R. D. (2007). Characteristics of hammer Stones and anvils used by wild bearded 
capuchin monkeys (Cebus libidinosus) to crack open palm nuts. American Journal of Physical Anthropology, 132, 426-444.

Westergaard, G. C. \& Suomi, S. J. (1994). A simple stone-tool technology in monkeys. Journal of Human Evolution, 27, 399-404.

Whiten, A. \& Ham, R. (1992). On the nature and evolution of imitation in the animal kingdom: reappraisal of a century of research. Advances in the Study of Behaviour, 21, 239-283.

Whiten, A., Goodall, J., McGrew, W. C., Nishida, T., Reynolds, V., Sugiyama, Y., Tutin, C .E. G., Wrangham, R. W. \& Boesch, C. (1999). Cultures in chimpanzees. Nature, 399, 682-685. 